\title{
WestVirginiaUniversity
}

THE RESEARCH REPOSITORY @ WVU

Graduate Theses, Dissertations, and Problem Reports

2000

\section{Assessing West Virginia NIPF owner characteristics and preferred assistance topics}

Daniel Joseph Magill

West Virginia University

Follow this and additional works at: https://researchrepository.wvu.edu/etd

\section{Recommended Citation}

Magill, Daniel Joseph, "Assessing West Virginia NIPF owner characteristics and preferred assistance topics" (2000). Graduate Theses, Dissertations, and Problem Reports. 1144.

https://researchrepository.wvu.edu/etd/1144

This Thesis is protected by copyright and/or related rights. It has been brought to you by the The Research Repository @ WVU with permission from the rights-holder(s). You are free to use this Thesis in any way that is permitted by the copyright and related rights legislation that applies to your use. For other uses you must obtain permission from the rights-holder(s) directly, unless additional rights are indicated by a Creative Commons license in the record and/ or on the work itself. This Thesis has been accepted for inclusion in WVU Graduate Theses, Dissertations, and Problem Reports collection by an authorized administrator of The Research Repository @ WVU. For more information, please contact researchrepository@mail.wvu.edu. 


\title{
Assessing West Virginia NIPF Owner Characteristics and Preferred Assistance Topics
}

\author{
Daniel J. Magill \\ Thesis Submitted to the College of Agriculture, Forestry and Consumer Sciences \\ at West Virginia University \\ in fulfillment of the requirements \\ for the degree of \\ Master of Science in \\ Forestry
}
Ray R. Hicks, Ph.D., Chair
Rory R. Fraser, Ph.D.
Ronald Althouse, Ph.D.

Departments of Forestry and Sociology Science

Morgantown, West Virginia

2000

Keyword: Non-Industrial-Private-Forest

Copyright 2000 Daniel J. Magill 


\title{
ABSTRACT \\ Assessing West Virginia NIPF Owner Characteristics and Preferred Assistance Topics
}

\author{
Daniel J. Magill
}

Four hundred and fifty-one Non-Industrial-Private-Forest (NIPF) owners (49\% response rate) in West Virginia responded to a survey of their forestry assistance needs. Most of the socioeconomic characteristics of the respondents, their reasons for owning the property, the types of activities they were engaged in on the property and the agencies that provided assistance by themselves significantly ( $\mathrm{Chi}^{2}$ \& ANOVA) differentiated those interested and not interested in obtaining assistance. However, when all 39 factors were considered together (Logistic Regression) only a small number of these factors were needed to explain the difference between landowners wanting and not wanting a specific assistance topic. Landowner income and tenure were recurrent factors in the logistic analysis. Results of the study can be used to target landowners for specific topics as well as gear workshops or programs that reflect the property uses and activities conducted by these landowners within their property.

The West Virginia State Division of Forestry provided grant funding for the project Improving Resource Management on Non-Industrial-Private-Forest lands in West Virginia through Assessment and Training. 


\section{Acknowledgements}

Let me begin by saying that words cannot express my sincerest appreciation to all those who have helped me achieve one of the greatest milestones of my life--a graduate degree from one of the finest institutions of higher learning in the country, West Virginia University. Since there are far too many people to thank individually, I would like to acknowledge the WVU faculty as a whole, especially the faculty and staff of the Departments of Forestry and Sociology for giving me the tools to achieve this educational goal.

I would also like to extend a special acknowledgement to several individuals, each of who provided me invaluable opportunities and assistance as an undergraduate and graduate student. To Bob Whipkey of the West Virginia Division of Forestry, I would like to say thank you for the generous financial and professional support you provided me during this project. I also thank Ed Collins and the county Extension Agents across the state that provided funding and contacts with landowners to conduct interviews and property case studies. Additionally, to Cliff Sypolt and the county agents of the USDA Farm Service Agency, I thank you for your logistic support to conduct mail surveys. I would also like to extend a very special thanks to Dr. Rory Fraser who provided me with excellent counseling, guidance and understanding that allowed me to accomplish this goal. To Dr Ray Hicks, I would like to thank you for guidance and the opportunity to participate in this project. I would also like to thank Dr. Ronald Althouse from the Department of Sociology for providing me with the knowledge to conduct landowner surveys. Finally, I would like to express my deep appreciation to my family for providing me with the time, patience and support to accomplish this educational objective. 


\section{Table of Contents}

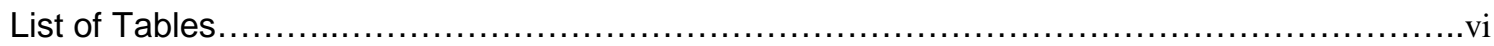

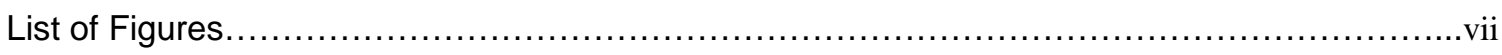

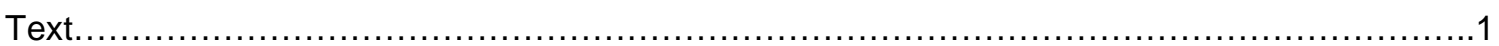

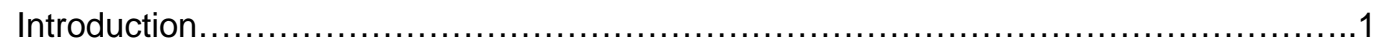

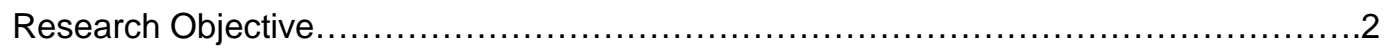

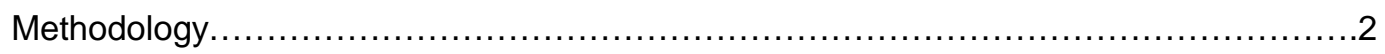

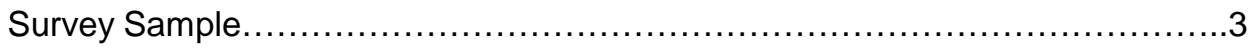

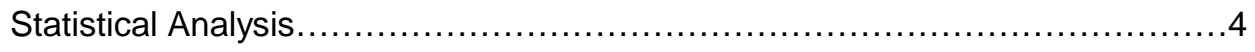

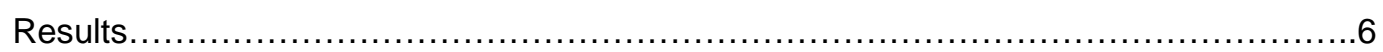

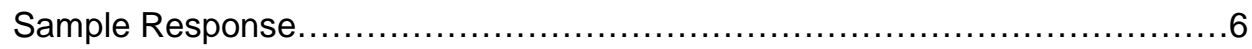

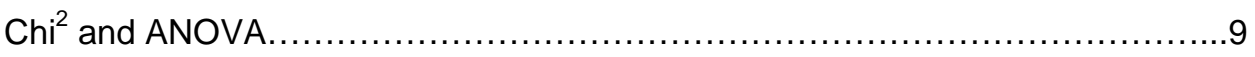

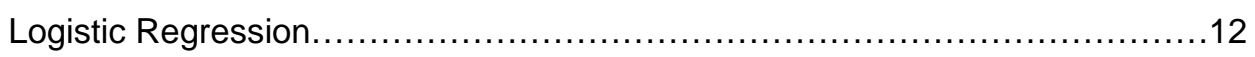

Summarizing the Logistic Regression Models ...............................17

Comparing West Virginia NIPF Owners to those in Idaho and Indiana...........19

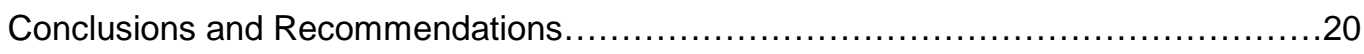

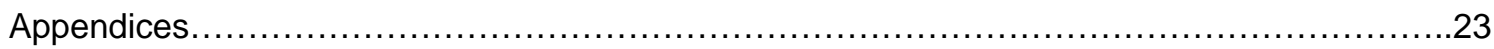

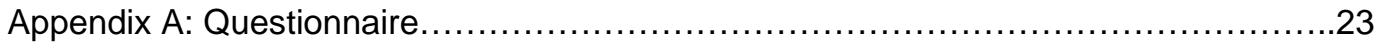

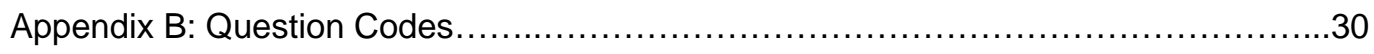

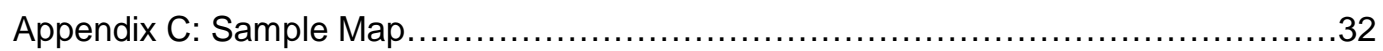

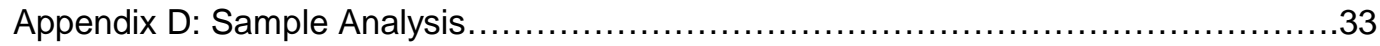

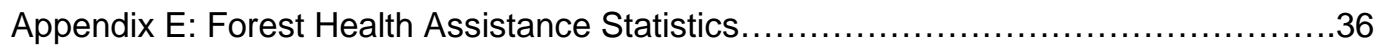

Appendix F: Water Resource Assistance Statistics................................40

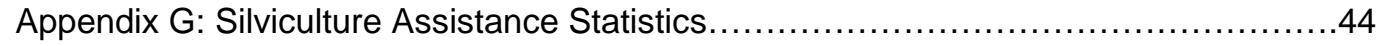

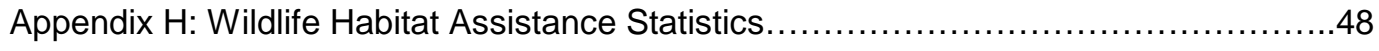

Appendix I: Landowner Liability, Property Rights and Tax Assistance Statistics...........52

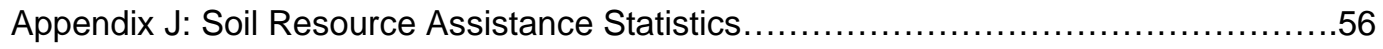

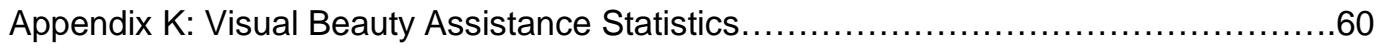


Appendix L: Dendrology Assistance Statistics.......................................64

Appendix M: Valuation Assistance Statistics............................................68

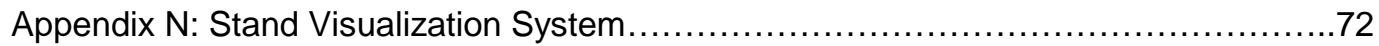

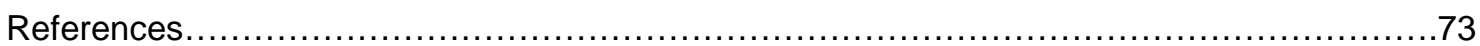




\section{List of Tables}

Table 1. Private Forest Ownership in West Virginia for 1991.

Table 2. Fifteen Dependent and 39 Independent Variables used in the Analysis.

Table 3. Comparing Pearson's $\mathrm{Chi}^{2} \mathrm{p}$-Values of Significance

Table 4. Comparing Analysis of Variance p-Values of Significance

Table 5. Comparing Logistic Regression p-Values of Significance 


\section{List of Figures}

Figure 1. West Virginia NIPF Sample Regions.

Figure 2. Landowners Sampled and Responding to the NIPF Survey by Region.

Figure 3. Landowners Sampled and Responding to the NIPF Survey by Cover Type.

Figure 4. Landowners Sampled and Responding to the NIPF Survey by Acreage Range.

Figure 5. Forestry Assistance Topics Preferred by 451 NIPF Owners 


\section{Introduction}

West Virginia is nearly $80 \%$ forested and forests are vital for sustaining its economy. According to a 1997 survey, the timber industry and related businesses in West Virginia contributed $\$ 3.2$ billion to the state's economy (Greenstreet and Caldwell, 1997). At the same time, nature-based tourism and recreation industries contributed $\$ 1.1$ billion: (Teisl, 1997; Maharaj and Carpenter, 1997; Meyers, 1997; Bailey, 1997). The $\$ 4.3$ billion of total economic benefit (includes multiplier effect) from forest resources made up 12\% of West Virginia's economic output in 1997. More importantly, these benefits were derived from resources that are renewable over the long-term, if they are properly managed. The private forestlands of West Virginia also provide a number of individual benefits such as privacy of residence, freedom of ownership and a sense of place. Other social benefits include forest recreational and subsistence uses as well as aesthetics, clean water and fresh air (Flora, 1992).

White (1993) reported that $83 \%$ of the forestland and $80 \%$ of the wood volume in West Virginia belonged to private landowners. According to a 1991 USDA Forest Service survey (Table 1), $75.7 \%$ of the privately owned forestland in the state belonged to NIPF owners while forest industries and other corporations owned the other 24.3\% (Birch, 1996). Improving resource management within the 256,500 NIPF ownership in West Virginia is significant, because less than $15 \%$ of these landowners are known to have received assistance in this decade (Magill et al., 2000). Additionally, there is now concern that the indiscriminate product harvesting and environmental damage of West Virginia's forest resources that occurred in the past is being repeated on our second-generation forests (Fajvan et al., 1998).

Table 1: Private Forest Ownership in West Virginia for 1991.

\begin{tabular}{|l|c|c|c|c|}
\hline Type of Owner & $\begin{array}{c}\text { Number of } \\
\text { Owners }\end{array}$ & $\begin{array}{c}\text { Percent } \\
\% \text { Owners }\end{array}$ & Acres & $\%$ Acres \\
\hline $\begin{array}{l}\text { Non-Industrial- } \\
\text { Private-Forest }\end{array}$ & 256,500 & $98.50 \%$ & $8,130,000$ & $75.70 \%$ \\
Corporation & 3,500 & $1.30 \%$ & $1,606,000$ & $14.90 \%$ \\
Forest Industry & 400 & $0.20 \%$ & $1,009,000$ & $9.40 \%$ \\
All Private Forests & 260,400 & $100 \%$ & $10,745,000$ & $100 \%$ \\
\hline
\end{tabular}

(Birch, 1996) 
Practicing stewardship on Non-Industrial-Private-Forest (NIPF) land is a way of countering this potential threat and offers the possibility for sustaining a flow of economic, as well as social, goods and services from the forests of West Virginia. Sustaining the environmental health of private forestland protects their biological assets. Forest ecosystem processes and functions result from the inter-relationships between soil, water, sunlight, plants and animals (Maser, 1994). Improper use and management of these assets can compromise the long-term health and productivity of the forest and limit the supply of forest products and services from which society derives many benefits (Best and Wayburn, 1995).

\section{Research Objective}

The objectives of this study were to determine the demographic characteristics of NIPF owners in West Virginia, their reasons for owning forest property, the type of forestry activities they have conducted on their property, who provided them with assistance and what specific topics of assistance they prefer. This information should provide the basis for a better understanding of NIPF owner interests, needs and problems of ownership and management. The information could then be used to develop and/or improve assistance programs for these NIPF landowners.

\section{Methodology}

The study was conducted through the combined efforts of the West Virginia University Extension Service (WVUES) and Division of Forestry (WVUDOF) as well as the West Virginia State Division of Forestry (WVDOF) and USDA Farm Service Agency (USDAFSA).

\section{$\underline{\text { Questionnaire }}$}

A seven-page questionnaire was used to collect data for the study. The components of this survey instrument were developed based on conversations with NIPF landowners and resource management professionals throughout West Virginia. Categories of questions were property size and ownership, forestland use and management, assistance received and 
demographic information (appendix A \& B). Mail surveys and personal interviews were conducted in the spring and summer of 1999 to collect NIPF owner information for the study. The study was conducted in three stages:

(i) Personal interviews with 20 landowners selected by County Extension Agents, (ii) Preliminary mail survey of 40 landowners contacted through the USDAFSA, and (iii) Mail survey of 1080 landowners based on the Dillman Method.

\section{Survey Sample}

Forty-percent of the landowners sampled were those listed as having properties with a written forest management plan under the West Virginia State Division of Forestry's Stewardship program (Whipkey, 1999). The other 60\% were those selected from USDA Farm Service Agency assistance lists (Sypolt, 1999). The sample was split to provide a fair representation of NIPF owners known to have a plan and those only having received assistance. A stratified sample (by region, forest cover, acreage and plans) method was used to determine if regional property location, percent of county in forest cover, property size and having a management plan or not influenced NIPF ownership and/or management decisions.

The state was first divided into three regional strata (northeastern, southern and northwestern) based on USDA Forest Service Forest Inventory and Regional Assessment (DiGiovanni, 1990). This was done to determine regional differences in landowner characteristics. The number of owners to sample was based on the total amount of forest acres owned by farmers and individuals in each region, which are common NIPF characteristics (Birch, 1996). Next, the number of landowners to sample by cover type in each region depended on how many counties were $80+\%$ or $60-79 \%$ in forest cover (DiGiovanni, 1990). As for example, if a region had seven $80+\%$ counties and nine counties $60-79 \%$ in forest cover more NIPF owners would be selected from the $60-79 \%$ counties. The sample included 49 counties. Six counties (Ohio, Brooke, Hancock, Harrison, Berkeley and Jefferson) were not sampled because they were $<60 \%$ forested. Sampling by percent forest cover was done because landowners in counties 
with extensive forest cover are more likely to be interested in managing their forest property (appendix C).

Landowners were then sampled based on acreage owned. The acreage stratification was to choose $85 \%$ owning $10-99$ acres, $11 \%$ with $100-199$ acres and $4 \%$ owning $200-299$ acres within each region. This minimum sampling acreage was used because landowners with less than 10 acres have limited management options (Gracey \& Pelkki, 1996). In contrast, the maximum of 299 acres was set because landowners controlling 300 or more acres are more likely to use private management services (Fraser \& Magill, 2000). The acreage range sampled was chosen because this group of landowner's control 55\% (average property size of 72 acres) of the $10,745,000$ privately owned forest acres in WV and potentially can have the most impact on forest resources (Birch, 1996).

According to Birch (1996) there were 114,600 private forest ownership's in WV consisting of 10 to 299 acres in 1994 , which is $44 \%$ of the 260,400 private owners in the state. The total sample of 1140 respondents for this survey was calculated as an approximate $1 \%$ sample of these 114,600 NIPF owners. Proportionally by region the total sample breakdown was $39 \%$ (446) in the northwestern, 35\% (399) from the northeastern and 26\% (295) in the southern region (Figure 1).

\section{$\underline{\text { Statistical Analysis }}$}

Pearson's $\mathrm{Chi}^{2}$, Analysis of Variance and logistic regression were used to analyze data in Statistica/PC. Data were analyzed to show significance at the alpha 0.10 level between independent and dependent variables. The dependent variables were the fifteen assistance topics included in the survey questionnaire (Table 2). Independent variables types included nominal, ordinal and continuous. The assistance topics were binary (Yes/No) and tested against 39 independent variables that included six demographics as well as fifteen property uses and fifteen management activities. In addition, the WVU Division of Forestry and Extension Service as well as the WV State Division of Forestry, were the assisting agencies included in the analysis (Table 2). The topics for which over $40 \%$ responded to in the survey were further analyzed. 
Table 2: Fifteen Dependent and 39 Independent Variables used in the Analysis

\begin{tabular}{|c|c|c|c|c|}
\hline \multicolumn{2}{|l|}{ Dependent Variables } & \multicolumn{2}{|c|}{ Independent Variables } & \multirow[b]{2}{*}{ Assisting Agencies } \\
\hline Assistance Topics & Demographics & Property Uses & Management Activities & \\
\hline Forest Health & Regional Location & Residence & Timber Harvest & WV State Division of Forestry \\
\hline Water Resources & Property Size & Investment & Planted Trees & WVU Division of Forestry \\
\hline Silviculture & Tenure & Wildlife Habitat & Thinned Trees & WVU Extension Service \\
\hline Wildlife Habitat & Income & Hunting or Fishing & Cut Vines or Other Plants & \\
\hline Liability & Age & Watershed Protection & Improved Visual Beauty & \\
\hline Soil Resources & Education & Visual Beauty & Constructed Trails & \\
\hline Visual Beauty & & Hiking or Biking & Constructed Roads & \\
\hline Dendrology & & Timber Production & Planted Wildlife Food Crops & \\
\hline Valuation & & Christmas Tree Farm & Improved Soil Resources & \\
\hline Access Roads & & Fruit Tree Orchard & Improved Water Resources & \\
\hline Survey Property & & Ginseng or Mushrooms & Non-timber Products & \\
\hline Non-timber Products & & Livestock Pasture & Surveyed Property & \\
\hline Forest Recreation & & Firewood or Fence Posts & Protected Forest Health & \\
\hline Management Coops & & Maple Syrup Production & Leased Property & \\
\hline Property Leases & & Other Uses & Other Activities (Built Fences) & \\
\hline 15 & 6 & 15 & 15 & 3 \\
\hline
\end{tabular}

Pearson's Chi ${ }^{2}$ was used to determine which landowner characteristics, both individually and proportionally, were significantly associated with an assistance topic. Property use questions were answered by ranking each use from most too least important and Pearson's $\mathrm{Chi}^{2}$ provided information to determine the rank importance of a significant property use. Using ANOVA provided a test of means to determine whether a significant landowner characteristic was negatively or positively associated with a specific assistance topic. If length of ownership were significant the test of means would indicate whether a shorter (negative) or longer (positive) term was prevalent for landowners interested in a certain assistant topic (Dowdy \& Wearden, 1987).

A separate logistic regression model was used for each of the assistance topics selected for further analysis. In the Logistic Regression model, the significance of any one of the 39 independent variables or characteristics is conditioned by the presence of all the other characteristics in the model (Hosmer \& Lemeshow, 1987). A significant characteristic in Pearson's $\mathrm{Chi}^{2}$ and the ANOVA, may not be significant once combined with the other characteristics in the model.

Nine additional logistic models were then run to test the significant characteristics of respondents interested in a specific assistance topic from the first model (39 df). As long as the 
reduction in the $\mathrm{Chi}^{2}$ values between the first and second models are not significant, the second models with less degrees of freedom are parsimonious for identifying the significant characteristics of respondents requesting a certain assistance topic. The significant characteristics in the second logistic models were the basis for determining if there are fundamental differences between landowners requesting and not requesting a certain assistance topic.

\section{Results}

\section{Sample Response}

The 511 landowners that responded to the survey consisted of the 20 interviewed; the 31 of 40 who returned the preliminary survey; and 460 who returned the mass-mailed survey. Although 511 landowners responded, 60 were excluded from this analysis, because they both own less than 10 acres or 300 or more acres; and are not within the range of 10 to 299 acres chosen for analysis.

The $49 \%$ rate of response was based on reducing the total sample of 1140 down to 923 relevant possibilities. The original sample size was reduced because 106 questionnaires were mailed to the wrong address. Additionally, fifty-one were returned blank because the landowner ether died, sold the property, cleared the forest or was unhappy with the questionnaire. These reasons along with not meeting the acreage requirement produced 451 relevant responses. The overall sample response of 451 landowners when analyzed by the $\mathrm{Chi}^{2}$ method proved representative across the state (appendix D-1 to D-3).

(i.) Regional Response:

Proportionally, the response by region was 36\% (161) from the northwestern, 39\% (175) in the northeastern and 25\% (115) from the southern region (Figure 1). 
Figure 1: Landowners Sampled and Responding to the NIPF Survey by Region

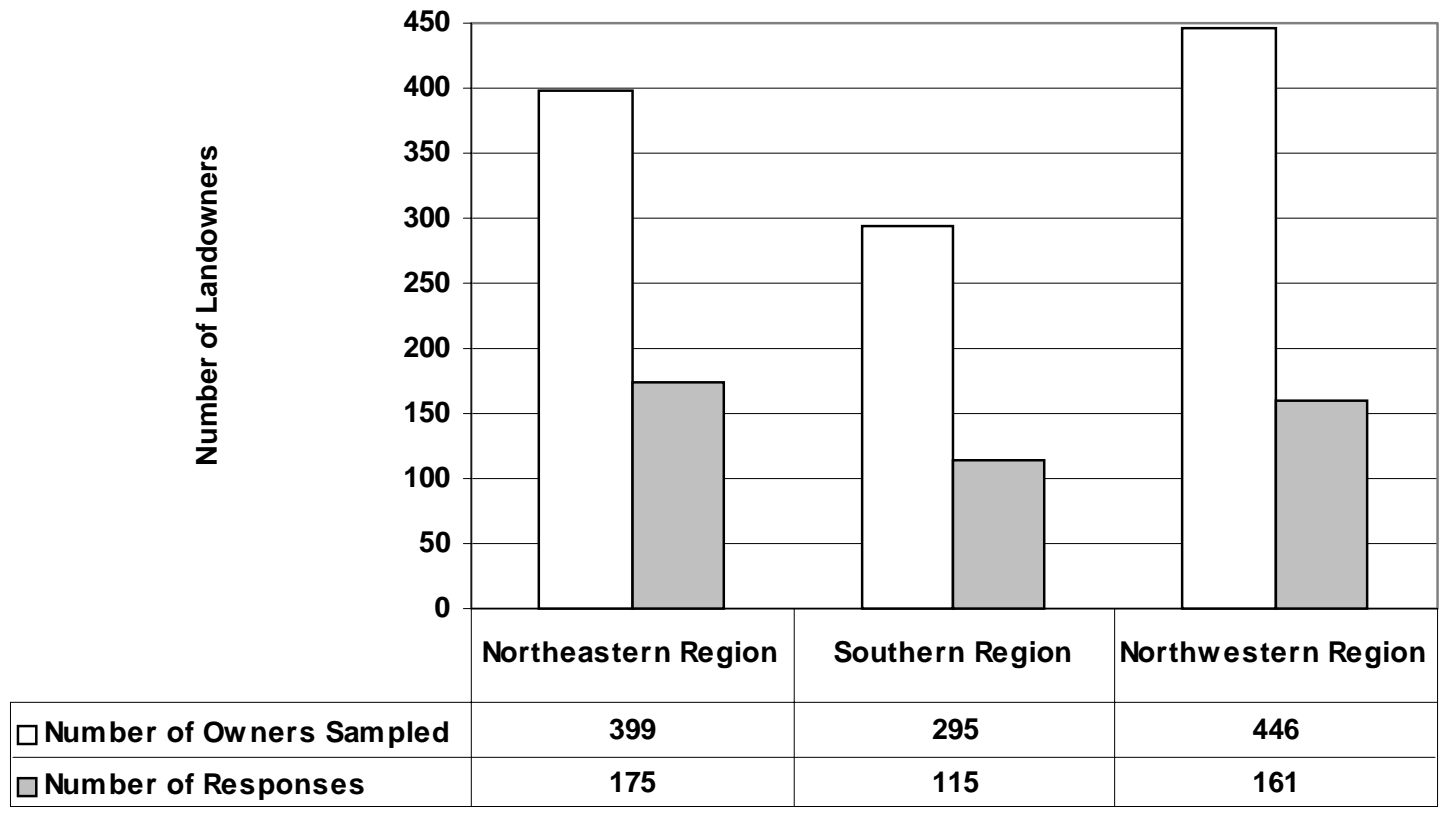

(ii.) Cover Type Response:

The proportion of returns by percent forest cover for all regions combined were $55 \%$ (250) from counties with $80+\%$ forest cover and $45 \%$ (201) received from counties in the $60-79 \%$ forest cover range (Figure 2). The only county from which landowners did not respond was McDowell, which is located in the southern sample region of the state.

Figure 2: Landowners Sampled and Responding to the NIPF Survey by Cover Type

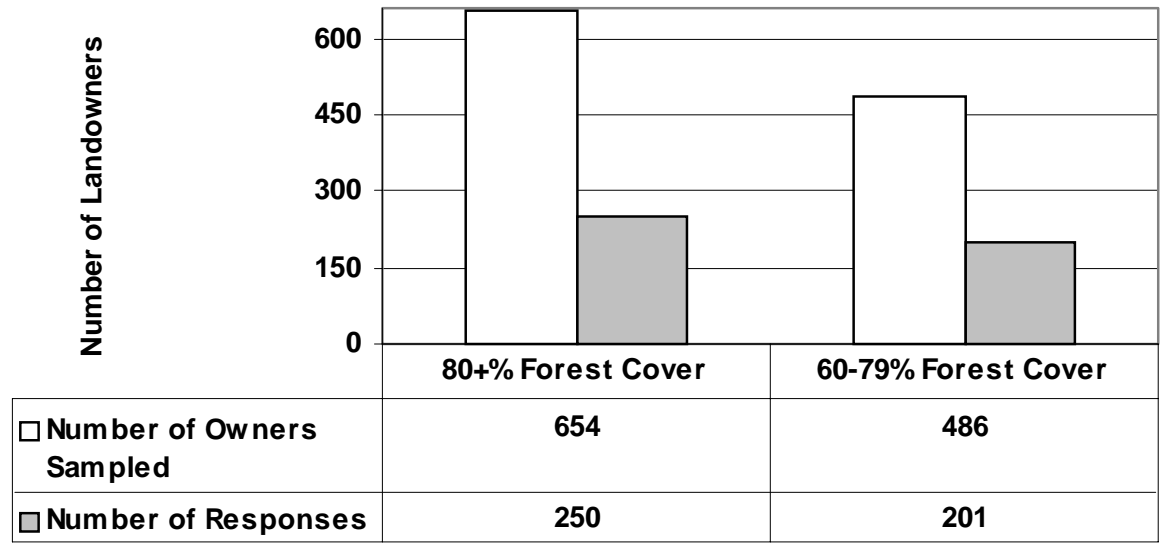


(iii.) Acreage Response

Response by acreage range across the state included $82 \%$ returned from those owning 10-99 acres, $13 \%$ with $100-199$ acres and 5\% owning $200-299$ acres of forest property (Figure 3).

Figure 3: Landowners Sampled and Responding to the NIPF Survey by Acreage Range

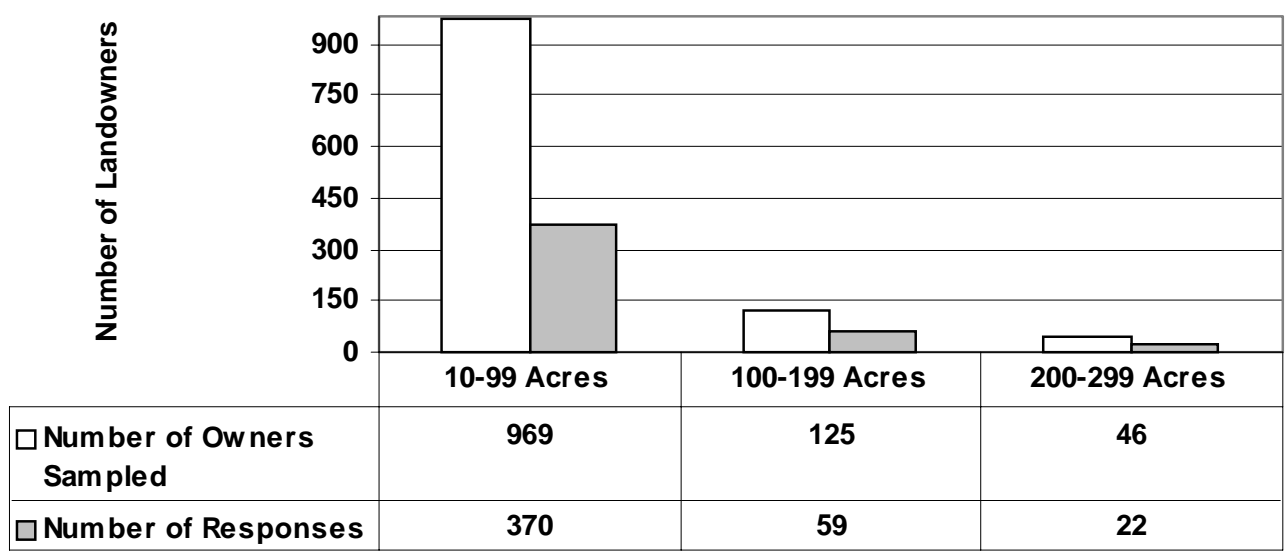

\section{Assistance Topics}

The statistical analysis of responses from this study of NIPF owners in West Virginia provide some interesting results. Nine of the fifteen assistance topics included in the survey were analyzed. The nine topics were chosen based on the number ( $\geq 40 \%$ of 451$)$ of owners $(\geq 180)$ requesting each topic of assistance. The most sought after topic was forest health followed by water resources, silviculture, wildlife habitat, landowner liability, soil resources, visual beauty, dendrology and silvics, valuation of timber or forestland (Figure 4). 
Figure 4: Forestry Assistance Topics Preferred by 451 NIPF Owners.

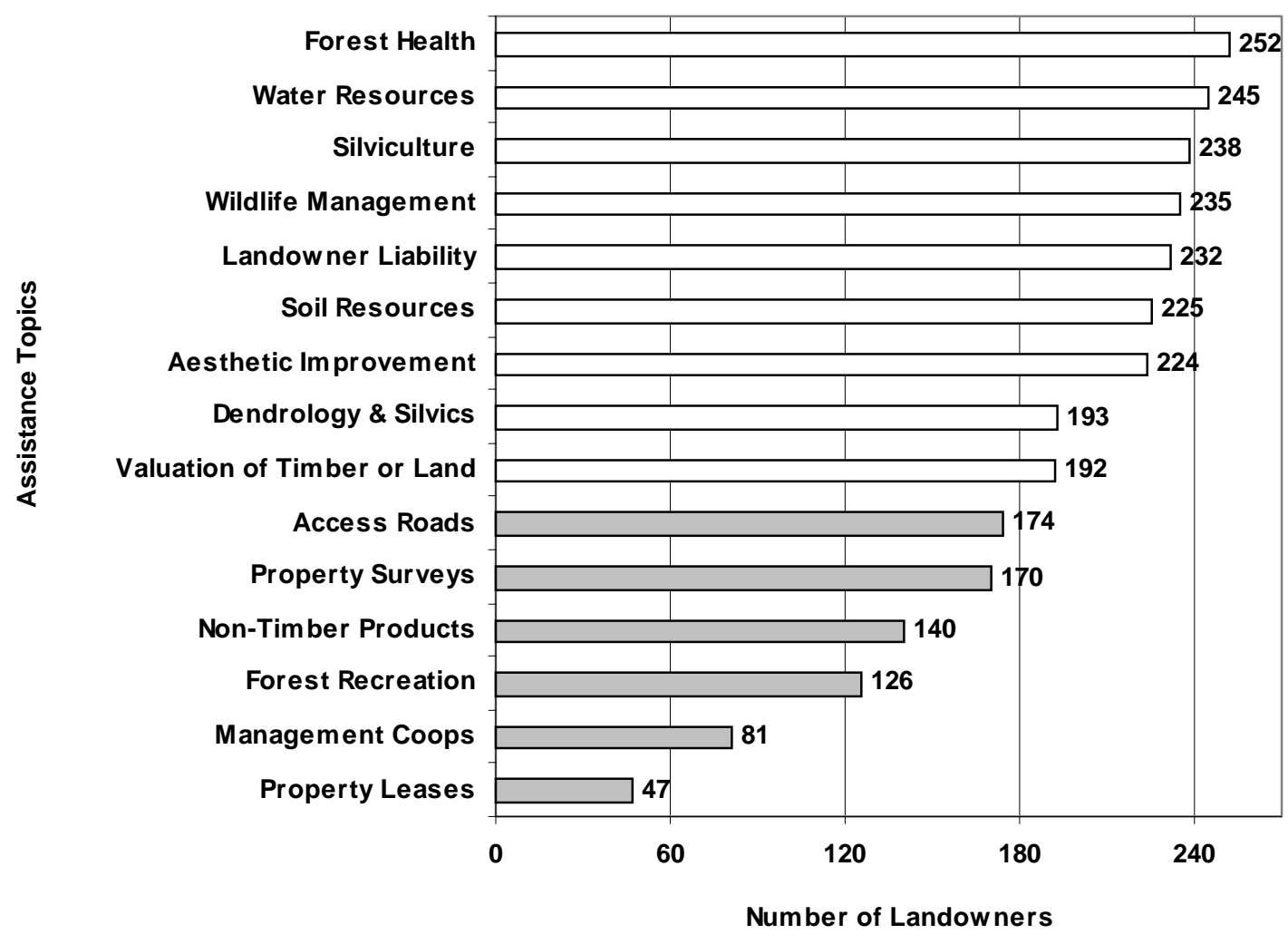

Pearson's $\mathrm{Chi}^{2}$ and Analysis of Variance (ANOVA)

Most of the 39 landowner-characteristics were significant in the $\mathrm{Chi}^{2}$ test of proportions and the ANOVA test of means (Tables $3 \& 4$ ). Years of property ownership and income level were consistently different between respondents interested and not interested in the nine preferred assistance topics (appendix E to M). However, some factors in both analysis types such as conducting timber harvest activities and property size were not consistently different for those wanting or not wanting a specific topic of assistance. On the other hand most of the reasons landowners that were interested in these nine topics gave for owning forest property and the activities they conducted on their land tested significantly different from those not interested. In addition, respondents interested in these topics were more likely to have received help from the three assisting agencies included in both analysis types (Tables 3 \& 4). 
Table 3: p-Values of Significance for Pearson's Chi ${ }^{2}$ test (Magill, 2000).

\begin{tabular}{|c|c|c|c|c|c|c|c|c|c|}
\hline & Depende & Variables & Nine Assista & e Topics & & & & & \\
\hline$p$-Value Significant $\leq 0.01^{* \star *}$ & FOREST & WATER & SILVICULTURE & WILDLIFE & LIABILITY & SOIL & VISUAL & DENDRO & VALUATION \\
\hline$p$-Value Significant $\leq 0.05^{* *}$ & HEALTH & RESOURCE & PRACTICES & HABITAT & ISSUES & RESOURCE & BEAUTY & ISSUES & ISSUES \\
\hline$p$-Value Significant $\leq 0.10^{*}$ & $p$-Value & p-Value & p-Value & p-Value & $p$-Value & p-Value & $p$-Value & p-Value & p-Value \\
\hline INDEPENDENT VARIABLES & & & & & & & & & \\
\hline DEMOGRAPHICS & & & & & & & & & \\
\hline REGION LOCATION IN WV & & & & ** & & & ** & * & ** \\
\hline LANDSIZE & & & & & & & & & 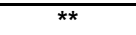 \\
\hline TENURE GROUP & * & ** & $\star \star \star \star$ & $\star \star \star \star$ & $\star \star \star \star$ & ** & $\star \star \star \star$ & $\star \star \star \star$ & 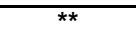 \\
\hline INCOME LEVEL & $\star \star$ & $\star \star \star \star$ & & $\star \star \star \star$ & $\star \star \star \star$ & * & $\star \star$ & $\star \star \star \star$ & $\star \star$ \\
\hline AGE GROUP & 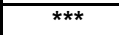 & $\star \star \star \star$ & 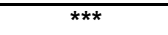 & $\star \star \star \star$ & 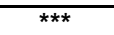 & 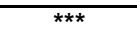 & 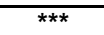 & 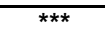 & $\star \star \star$ \\
\hline EDUCATION LEVEL & & & & & & & & ** & $\star \star \star *$ \\
\hline PROPERTY USES & & & & & & & & & \\
\hline PLACE OF RESIDENCE & $\star \star \star \star$ & * & * & $\star \star \star \star ~$ & * & * & $\star \star \star \star$ & * & *** \\
\hline INVESTMENT & $\star \star \star \star$ & $\star \star \star \star$ & $\star \star \star \star$ & $\star \star \star \star$ & $\star \star \star \star$ & $\star \star \star \star$ & $\star \star \star \star$ & $\star \star \star \star$ & $\star \star \star \star$ \\
\hline WILDLIFE HABITAT & $\star \star \star \star$ & $\star \star \star \star$ & $\star \star \star \star$ & $\star \star \star \star$ & $\star \star \star \star$ & $\star \star \star \star$ & $\star \star \star \star$ & $\star \star \star \star$ & $\star \star \star \star$ \\
\hline HUNTING OR FISHING & $\star \star \star$ & $\star \star \star \star$ & $\star \star \star \star$ & $\star \star \star \star$ & 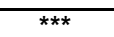 & 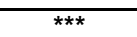 & * & $\star \star \star \star$ & $\star \star \star \star *$ \\
\hline WATESHED PROTECTION & $\star \star \star \star$ & $\star \star \star \star$ & $\star * * *$ & $\star \star \star \star$ & $\star \star \star *$ & ** & $\star \star \star$ & $\star \star \star \star$ & 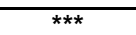 \\
\hline VISUAL BEAUTY & 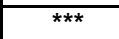 & 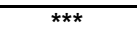 & 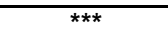 & $\star \star \star \star$ & $\star \star \star \star$ & $\star \star \star$ & $\star \star \star$ & $\star \star \star \star$ & $\star \star \star$ \\
\hline HIKING OR BIKING & 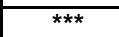 & $\star \star \star \star$ & 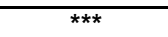 & $\star \star \star \star$ & 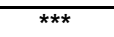 & $\star \star \star$ & $\star \star \star \star$ & $\star \star \star \star$ & 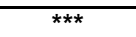 \\
\hline TIMBER PRODUCTION & 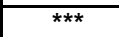 & $\star \star \star \star$ & $\star \star \star \star$ & $\star \star \star$ & $\star \star \star \star$ & $\star \star \star$ & $\star \star \star \star$ & $\star \star \star \star$ & 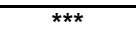 \\
\hline CHRISTMAS TREE FARM & $\star \star \star$ & $\star \star \star \star$ & $\star \star \star \star$ & $\star \star \star \star$ & 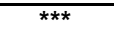 & $\star \star \star \star$ & $\star \star \star \star$ & $\star \star \star \star$ & $\star \star$ \\
\hline FRUIT TREE ORCHARD & $\star \star \star \star$ & $\star \star \star \star$ & 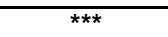 & $\star \star \star \star$ & ** & $\star \star \star \star$ & $\star \star \star \star$ & $\star \star \star \star$ & 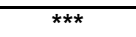 \\
\hline GINSENG OR MUSHROOMS & $\star \star \star \star$ & $\star \star \star \star$ & $\star \star \star \star$ & $\star \star \star \star$ & $\star \star \star \star$ & $\star \star \star \star$ & $\star \star \star \star$ & $\star \star \star \star$ & 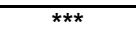 \\
\hline LIVESTOCK PASTURE & $\star \star \star \star$ & $\star \star \star \star$ & $\star \star \star \star$ & $\star \star \star$ & $\star \star \star$ & $\star \star \star \star$ & $\star \star \star \star$ & $\star \star \star \star$ & $\star \star \star$ \\
\hline FIREWOOD OR POSTS & $\star \star \star \star$ & * & 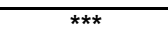 & $\star \star \star \star$ & ** & & & ** & $\star \star \star *$ \\
\hline MAPLE SYRUP & $\star \star \star \star$ & $\star \star \star \star$ & $\star \star \star *$ & $\star \star \star \star$ & $\star \star$ & $\star \star \star \star$ & $\star \star \star \star$ & 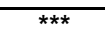 & $\star \star \star$ \\
\hline OTHER USES & 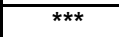 & $\star \star$ & 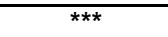 & $\star \star$ & $\star \star$ & $\star \star \star \star$ & $\star \star \star \star$ & $\star \star \star \star$ & $\star \star \star$ \\
\hline FOREST ACTIVITY & & & & & & & & & \\
\hline TIMBER HARVESTING & & * & & ** & & & & & \\
\hline PLANTED TREES & $\star \star \star$ & $\star \star \star \star$ & $\star \star \star \star$ & $\star \star \star \star$ & & * & & $\star \star \star \star$ & \\
\hline THINNED TREES & $\star \star \star \star$ & $\star \star \star \star$ & 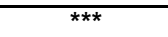 & $\star \star \star \star$ & & * & 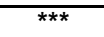 & 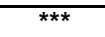 & \\
\hline CUT GRAPEVINES & $\star \star \star \star$ & 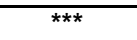 & $\star \star \star \star$ & 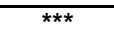 & ** & $\star \star *$ & $\star \star$ & 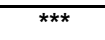 & 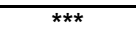 \\
\hline IMPROVE VISUAL BEAUTY & 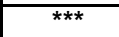 & $\star \star \star \star$ & 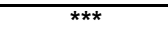 & $\star \star \star \star$ & ** & ** & 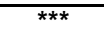 & ** & \\
\hline CONSTRUCTED TRAILS & $\star \star \star \star$ & 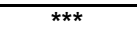 & 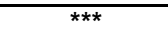 & $\star \star \star \star$ & 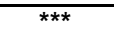 & ** & $\star \star$ & $\star \star \star \star$ & 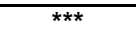 \\
\hline CONSTRUCTED ROADS & $\star \star$ & $\star \star \star \star$ & 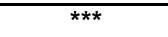 & $\star \star \star \star$ & * & $\star \star \star \star$ & & ** & \\
\hline WILDLIFE FOOD CROPS & & 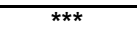 & ** & 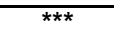 & & 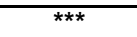 & 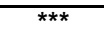 & 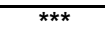 & \\
\hline IMPROVED SOIL & $\star \star \star \star$ & 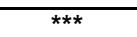 & * & ** & * & 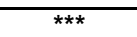 & * & & \\
\hline IMPROVED WATER & $\star \star *$ & 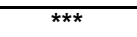 & & ** & $\star \star$ & ** & & & \\
\hline NON-TIMBER PRODUCTS & ** & $\star \star \star *$ & 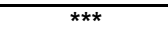 & 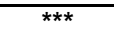 & & * & & $\star \star \star \star$ & \\
\hline SURVEYED PROPERTY & $\star \star$ & $\star \star \star \star$ & & $\star \star \star$ & & $\star \star \star \star$ & 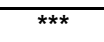 & 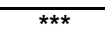 & $\star \star$ \\
\hline FOREST HEALTH & $\star \star \star \star$ & $\star \star$ & 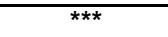 & 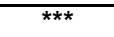 & 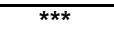 & 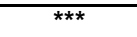 & 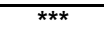 & & \\
\hline LEASED PROPERTY & 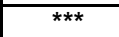 & & & & * & & & * & * \\
\hline OTHER ACTIVITIES & & & 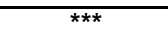 & & & 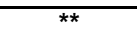 & & & 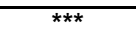 \\
\hline ASSISTING AGENCIES & & & & & & & & & \\
\hline WVU DIVISION OF FORESTRY & & 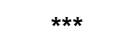 & ** & $\star \star \star$ & 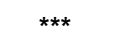 & & ** & & 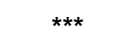 \\
\hline WVU EXTENSION SERVICE & $\star \star \star \star$ & $\star \star \star \star$ & 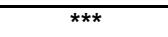 & $\star \star \star \star$ & $\star \star \star \star$ & ** & 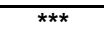 & $\star \star \star \star$ & $\star \star$ \\
\hline WV DIVISION OF FORESTRY & $\star \star \star \star$ & $\star \star \star \star$ & 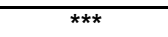 & $\star \star \star \star$ & 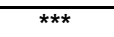 & $\star \star \star \star$ & 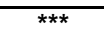 & 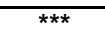 & $\star * \star *$ \\
\hline
\end{tabular}


Table 4: p-Values of Significance for Analysis of Variance (Magill, 2000).

Dependent and Grouping Variables = Nine Assistance Topics

\begin{tabular}{|c|c|c|c|c|c|c|c|c|c|}
\hline $\begin{array}{l}p \text {-Value Significant } \leq 0.01^{* * *} \\
p \text {-Value Significant } \leq 0.05^{* *} \\
p \text {-Value Significant } \leq 0.10^{*}\end{array}$ & $\begin{array}{c}\text { FOREST } \\
\text { HEALTH } \\
\text { p-Value }\end{array}$ & $\begin{array}{c}\text { WATER } \\
\text { RESOURCE } \\
\text { p-Value }\end{array}$ & $\begin{array}{l}\text { SILVICULTURE } \\
\text { PRACTICES } \\
\text { p-Value }\end{array}$ & $\begin{array}{c}\text { WILDLIFE } \\
\text { HABITAT } \\
\text { p-Value }\end{array}$ & $\begin{array}{l}\text { LIABILITY } \\
\text { ISSUES } \\
\text { p-Value }\end{array}$ & $\begin{array}{c}\text { SOIL } \\
\text { RESOURCE } \\
\text { p-Value }\end{array}$ & $\begin{array}{l}\text { VISUAL } \\
\text { BEAUTY } \\
\text { p-Value }\end{array}$ & $\begin{array}{l}\text { DENDRO } \\
\text { ISSUES } \\
\text { p-Value }\end{array}$ & $\begin{array}{l}\text { VALUATION } \\
\text { ISSUES } \\
\text { p-Value }\end{array}$ \\
\hline \multicolumn{10}{|l|}{ INDEPENDENT VARIABLES } \\
\hline \multicolumn{10}{|l|}{ DEMOGRAPHICS } \\
\hline LANDSIZE & $+^{*}$ & & $+^{*}$ & & & & & & 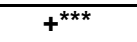 \\
\hline \multirow{2}{*}{$\begin{array}{l}\text { TENURE } \\
\text { INCOME }\end{array}$} & 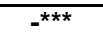 & 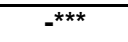 & $-* * *$ & $-\star \star \star \star$ & 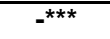 & 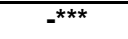 & 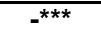 & $-\star \star \star \star$ & $-\star \star$ \\
\hline & $+^{\star \star \star}$ & $+^{\star \star \star}$ & $t^{\star \star}$ & $+^{\star \star \star}$ & $+^{\star \star \star}$ & $+^{\star \star \star}$ & $+^{\star \star \star}$ & $+^{\star \star \star}$ & $+^{\star \star \star}$ \\
\hline \multicolumn{10}{|l|}{ AGE } \\
\hline EDUCATION & $+{ }^{\star \star}$ & $+t^{\star \star \star}$ & $+^{*}$ & & $+t^{\star \star \star}$ & & & & $+t^{\star \star \star}$ \\
\hline \multirow{2}{*}{\multicolumn{10}{|c|}{ PLACE OF RESIDENCE }} \\
\hline & & & & & & & & & \\
\hline \multirow[b]{2}{*}{ WILDLIFE HABITAT } & $t^{\star \star \star}$ & $t^{\star \star \star}$ & $+^{\star \star \star}$ & $t^{\star \star \star}$ & $t^{\star \star \star}$ & $+^{\star \star \star}$ & $+^{\star \star \star}$ & $t^{\star \star \star}$ & $t^{\star \star \star}$ \\
\hline & $+^{\star \star \star}$ & $t^{\star \star \star}$ & $+^{\star \star \star}$ & $+^{\star \star \star}$ & $t^{\star \star \star}$ & $+t^{\star \star \star}$ & $+^{\star \star \star}$ & $+^{\star \star \star}$ & $+{ }^{\star \star \star}$ \\
\hline \multirow{2}{*}{$\begin{array}{l}\text { HUNTING OR FISHING } \\
\text { WATESHED PROTECTION }\end{array}$} & $t^{\star \star \star}$ & $+^{\star \star \star}$ & $+{ }^{\star \star}$ & $t^{\star \star \star}$ & $t^{\star \star \star}$ & $+t^{\star \star \star}$ & $+{ }^{\star \star}$ & $++^{\star \star \star}$ & $t^{\star \star}$ \\
\hline & $+^{\star \star \star}$ & $t^{\star \star \star}$ & $+^{\star \star \star}$ & $t^{\star \star \star}$ & $t^{* \star}$ & $+^{\star \star \star}$ & $+^{\star \star \star}$ & $+^{\star \star \star}$ & $t^{\star \star}$ \\
\hline VISUAL BEAUTY & $+^{\star \star \star}$ & $t^{\star \star \star}$ & $+^{\star \star \star}$ & $t^{\star \star \star}$ & $t^{\star \star \star}$ & $t^{\star \star \star}$ & $+^{\star \star \star}$ & $+^{\star \star \star}$ & $+^{\star \star \star}$ \\
\hline HIKING OR BIKING & $+^{\star \star \star}$ & $t^{\star \star \star}$ & $+^{\star \star \star}$ & $t^{\star \star \star}$ & $t^{\star \star \star}$ & $t^{\star \star}$ & $+^{\star \star \star}$ & $+^{\star \star \star}$ & $t^{\star \star \star}$ \\
\hline TIMBER PRODUCTION & $+t^{\star \star \star}$ & $t^{\star \star \star}$ & $+t^{\star \star \star}$ & $+t^{\star \star \star}$ & $+t^{\star \star \star}$ & $+t^{\star \star \star}$ & $+^{\star \star \star}$ & 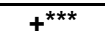 & 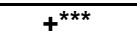 \\
\hline CHRISTMAS TREE FARM & $+^{\star \star \star}$ & $t^{\star \star \star}$ & $+^{\star \star \star}$ & $+^{\star \star \star}$ & $t^{\star \star \star}$ & $+^{\star \star \star}$ & $+^{\star \star \star}$ & $t^{\star \star \star}$ & $t^{\star \star}$ \\
\hline FRUIT TREE ORCHARD & $+t^{\star \star \star}$ & $t^{\star \star \star}$ & $t^{\star \star \star}$ & $t^{\star \star \star}$ & $+{ }^{* \star}$ & $t^{\star \star \star}$ & $+^{\star \star \star}$ & $t^{\star \star \star}$ & \\
\hline \multirow{2}{*}{$\begin{array}{l}\text { GINSENG OR MUSHROOMS } \\
\text { LIVESTOCK PASTURE }\end{array}$} & $++^{\star \star \star}$ & $+^{\star \star \star}$ & $t^{\star \star \star}$ & $+{ }^{\star \star \star}$ & $t^{\star \star \star}$ & $t^{\star \star \star}$ & $+^{\star \star \star}$ & $+^{\star \star \star}$ & \\
\hline & $+{ }^{\star \star}$ & $+t^{\star \star \star}$ & & & & $t^{\star \star \star}$ & & $+^{*}$ & \\
\hline \multirow[t]{2}{*}{ FIREWOOD OR POSTS } & $+t^{\star \star \star}$ & & $t^{\star \star \star}$ & & $+{ }^{\star \star}$ & $+^{*}$ & $+{ }^{\star \star}$ & $+t^{\star \star \star}$ & \\
\hline & $+{ }^{\star \star \star}$ & $++^{\star \star \star}$ & $t^{\star \star \star}$ & $++^{\star \star \star}$ & $+{ }^{\star *}$ & $t^{\star \star \star}$ & $+t^{\star \star \star}$ & $+t^{\star \star \star}$ & \\
\hline OTHER USES & $+{ }^{\star \star \star}$ & $+^{*}$ & $++^{\star \star \star}$ & $+^{\star \star *}$ & $+t^{\star \star \star}$ & $+{ }^{\star \star}$ & $+t^{\star \star \star}$ & $+t^{\star \star \star}$ & $t^{\star \star \star}$ \\
\hline \multicolumn{10}{|l|}{ FOREST ACTIVITY } \\
\hline \multirow{2}{*}{$\begin{array}{l}\text { TIMBER HARVESTING } \\
\text { PLANTED TREES }\end{array}$} & & $+^{*}$ & & & & & & & \\
\hline & $+t^{\star \star \star}$ & $++^{\star \star \star}$ & $t^{\star \star \star}$ & $t^{\star \star \star}$ & & $+^{*}$ & & $t^{\star \star \star}$ & \\
\hline THINNED TREES & $++^{\star \star \star}$ & $+{ }^{\star \star \star}$ & $++^{\star \star \star}$ & $+{ }^{\star \star \star}$ & & $+^{\star}$ & $++^{\star \star \star}$ & $+^{\star \star \star}$ & \\
\hline \multirow{2}{*}{$\begin{array}{l}\text { CUT GRAPEVINES } \\
\text { IMPROVE VISUAL BEAUTY }\end{array}$} & $++^{\star \star \star}$ & $++^{\star \star \star}$ & $+t^{\star \star \star}$ & $+t^{\star \star \star}$ & $+{ }^{\star \star}$ & $++^{\star \star}$ & $+{ }^{\star \star}$ & $+t^{\star \star \star}$ & $t^{\star \star \star}$ \\
\hline & $+{ }^{\star \star \star}$ & $+{ }^{\star \star \star}$ & $+{ }^{\star \star \star}$ & $+{ }^{\star \star \star}$ & $+{ }^{\star \star}$ & $+{ }^{\star \star}$ & $+t^{\star \star \star}$ & $+^{\star \star}$ & \\
\hline CONSTRUCTED TRAILS & $+^{\star \star \star}$ & $+^{\star \star \star}$ & $+^{\star \star \star}$ & $+^{\star \star \star}$ & $t^{\star \star \star}$ & $++^{\star \star}$ & $+^{\star \star}$ & $+^{\star \star \star}$ & $+t^{\star \star \star}$ \\
\hline CONSTRUCTED ROADS & $+{ }^{\star \star}$ & $+{ }^{\star \star \star}$ & $t^{\star \star \star}$ & $+t^{\star \star \star}$ & $+^{*}$ & $t^{\star \star \star}$ & & $+{ }^{\star \star}$ & \\
\hline WILDLIFE FOOD CROPS & $t^{\star \star \star}$ & $t^{\star \star \star}$ & $+{ }^{\star \star}$ & $+^{\star \star}$ & & $t^{\star \star \star}$ & $t^{\star \star \star}$ & $t^{\star \star \star}$ & \\
\hline IMPROVED SOIL & $t^{\star \star \star}$ & $t^{\star \star \star}$ & $+^{*}$ & $+^{*}$ & $+^{*}$ & $t^{\star \star \star}$ & $+^{*}$ & & \\
\hline IMPROVED WATER & $+{ }^{\star \star}$ & $+^{\star \star \star}$ & & & $t^{\star \star}$ & $+{ }^{\star \star}$ & & & \\
\hline NON-TIMBER PRODUCTS & $+{ }^{\star \star}$ & $+^{\star \star \star}$ & $t^{\star \star \star}$ & $+^{\star \star \star}$ & & $+^{*}$ & & $t^{\star \star \star}$ & \\
\hline SURVEYED PROPERTY & $+{ }^{\star \star}$ & $t^{\star \star \star}$ & & & & $t^{\star \star \star}$ & $+^{\star \star \star}$ & $t^{\star \star \star}$ & $+^{\star \star}$ \\
\hline FOREST HEALTH & $+{ }^{\star \star \star}$ & $+{ }^{\star \star}$ & $t^{\star \star \star}$ & $t^{\star \star \star}$ & $t^{\star \star \star}$ & $t^{\star \star \star}$ & $t^{\star \star \star}$ & & \\
\hline LEASED PROPERTY & $t^{\star \star \star}$ & & & & $+^{*}$ & & & $+^{*}$ & $+^{*}$ \\
\hline OTHER ACTIVITIES & & & $t^{\star \star \star}$ & 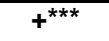 & & $+{ }^{\star \star}$ & & & $+^{\star \star \star}$ \\
\hline ASSISTING AGENCIES & & & & & & & & & \\
\hline WVU DIVISION OF FORESTRY & & $+^{\star \star \star}$ & $+{ }^{\star \star}$ & $+t^{\star \star \star}$ & $t^{\star \star \star}$ & & $+{ }^{\star \star}$ & & $+^{\star \star \star}$ \\
\hline WVU EXTENSION SERVICE & $t^{\star \star \star}$ & $+^{\star \star \star}$ & $+^{\star \star \star}$ & $t^{\star \star \star}$ & $t^{\star \star \star}$ & $+t^{\star \star}$ & $+^{\star \star \star}$ & $+^{\star \star \star}$ & $t^{\star \star}$ \\
\hline WV DIVISION OF FORESTRY & $+t^{* \star *}$ & $+{ }^{\star \star \star}$ & $+t^{\star \star \star}$ & $t^{\star \star \star}$ & $+t^{\star \star \star}$ & $t^{\star \star \star *}$ & $+t^{\star \star \star}$ & $+t^{\star \star \star}$ & $+t^{\star \star \star}$ \\
\hline
\end{tabular}




\section{Logistic Regression Analysis (Nine Models)}

The logistic models used in the analysis identified the most important characteristics of landowners interested in the nine preferred assistance topics. Lowering the degrees of freedom to an average of six in the models from 39 in the ANOVA and $\mathrm{Chi}^{2}$ analysis did not significantly reduce the $\mathrm{Chi}^{2}$ value making the models parsimonious for predicting these landowners. This means that fewer characteristics were needed in the regression analysis to identify respondents wanting one of these topics of assistance. The odds ratio calculated for each model was also good with an average of 4.2:1 meaning that the significant factors as a group in these models can be used to correctly predict on average every four (80\%) out of five landowners wanting or not wanting a specific topic. Additionally, the models on average accurately identified $67 \%$ and $66 \%$ of those interested and not interested respectfully, in these topics of assistance based on individual significant factors in the models. (Table 5 \& appendix $E$ to $M$ ).

\section{(i.) Forest Health:}

Landowners interested in forest health issues tend to have higher income levels and use their property for wildlife habitat as well as timber production. They were also more inclined to be engaged in protecting the health of their forest and leasing their property for timber or recreational benefits. In addition, the West Virginia State Division of Forestry was an important source of assistance in the past for respondents wanting help to protect their forest property. These significant characteristics suggest that this group of landowners realize that poor forest health can jeopardize habitat for wildlife and while also negatively influencing the leasing of their forest

property (Table 5). During personal interviews with NIPF owners and case-study visits to their property it was also evident that problems with gypsy moth, deer damage, grapevines, fire and poor timber harvesting practices were of great concern and the landowners were not sure how to deal with these problems (Magill, 2000). 
(ii.) Water Resources:

Obtaining assistance to improve water quality and quantity was more likely to be requested by landowners earning higher incomes and owning their property for livestock pasturage. Additionally, this group of respondents tends to have conducted water improvement practices on their property while also previously receiving assistance from the West Virginia State Division of Forestry. The positive relationships between these characteristics indicates that this group of landowners is aware of the management required to sustain water resources for supporting their reasons of ownership, but they are in need of further assistance (Table 5). This was also evident during discussions and case study visits with NIPF owners who were interested in maintaining an adequate supply of clean water for wildlife and livestock (Magill, 2000).

(iii.) Silviculture:

Respondents interested in receiving assistance for planting, growing, thinning or harvesting trees and other forest plants as well as controlling grapevines (silviculture) tend to be more recent forest owners. Owning property for investment and timber production as well as growing or harvesting non-timber products (ginseng etc.) and building fences were identifying characteristics for landowners wanting silviculture assistance. Landowners interested in silviculture issues were also more likely to have gotten assistance in the past from the West Virginia State Division of Forestry. The relationship between these characteristics suggests that this group of landowners recognize that their preferred property uses and forest activities require silviculture assistance, which can be economically and biologically complicated (Table 5). NIPF owners who were visited for interview and case study also expressed an interests in and concern about silvicultural issues (Magill, 2000).

(iv.) Wildlife Management:

Getting assistance for improving wildlife habitat and food sources tended to be requested by more recent forest owners with higher incomes who also use their property for residence, hunting or fishing and wildlife habitat. Landowners more inclined to be interested in wildlife 
management issues also tend to have established wildlife food crops on their property. The West Virginia State Division of Forestry was also indicated by this group of respondents as having provided them assistance in the past. The negative relationship between watershed protection and managing wildlife suggests that this group of landowners would like to be assisted in managing their property for wildlife without disrupting watershed quality. In contrast, the positive correlation among the other characteristics indicates that respondents interested in wildlife management issues seem to realize they need assistance to achieve their ownership and management objectives (Table 5). Receiving assistance for improving and managing wildlife habitat was also an important topic of interest and concern during conversations and property visits with NIPF owners (Magill, 2000).

(v.) Liability, Property Rights and Tax Issues:

Landowners interested in improving their knowledge of landowner liability, property rights or taxes tend to have higher incomes and be more recent forest owners as well as own their property for investment and ginseng or mushroom production. They were also more inclined to protect their forest property and tend to have previously received assistance from the West Virginia State Division of Forestry. Even though thinning trees was a significant activity, it was negatively correlated with requests for this assistance topic, which suggests that these landowners may want to know their liability rights before conducting tree thinnings. The positive relationship between the other significant factors indicates that these landowners want to protect their forest property investment while preserving their property rights (Table 5). NIPF owners that were visited also indicated a concern about their ownership liability while also revealing a general uneasiness with their involvement in assistance programs in relation to property rights and taxes. However, they did show an interest of wanting to be more informed about these issues (Magill, 2000). 
Table 5: p-Values of Significance for Logistic Regression Models (Magill, 2000).

\begin{tabular}{|c|c|c|c|c|c|c|c|c|c|}
\hline \multirow[b]{2}{*}{$\mathrm{p}$-Value Significant $\leq 0.01^{* * \star}$} & \multicolumn{9}{|c|}{ Dependent Variables = Nine Assistance Topics } \\
\hline & FOREST & WATER & SILVICULTURE & WILDLIFE & LIABILITY & SOIL & VISUAL & DENDRO & VALUATION \\
\hline$p$-Value Significant $\leq 0.05^{* *}$ & HEALTH & RESOURCE & PRACTICES & HABITAT & ISSUES & RESOURCE & BEAUTY & ISSUES & ISSUES \\
\hline$p$-Value Significant $\leq 0.10$ * & p-Value & $\mathrm{p}$-Value & p-Value & p-Value & p-Value & p-Value & p-Value & p-Value & p-Value \\
\hline \multicolumn{10}{|l|}{ INDEPENDENT VARIABLES } \\
\hline \multicolumn{10}{|l|}{ DEMOGRAPHICS } \\
\hline \multirow{2}{*}{$\begin{array}{l}\text { TENURE GROUP } \\
\text { INCOME LEVEL }\end{array}$} & & & 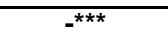 & 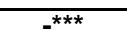 & $-\star \star *$ & $-{ }^{*}$ & & $-\star \star \star \star$ & \\
\hline & $+{ }^{\star \star}$ & $+{ }^{\star \star \star}$ & & $t^{\star *}$ & $t^{\star \star \star}$ & $+t^{\star \star}$ & & & \\
\hline \multirow{2}{*}{\multicolumn{10}{|c|}{ PLACE OF RESIDENCE }} \\
\hline & & & & & & & & & \\
\hline \multirow{2}{*}{$\begin{array}{l}\text { INVESTMENT } \\
\text { WILDLIFE HABITAT }\end{array}$} & & & $+t^{\star \star \star}$ & & $+t^{\star \star \star}$ & & & $+t^{\star \star \star}$ & $+t^{\star \star \star}$ \\
\hline & $t^{\star \star \star}$ & & & $+t^{\star \star \star}$ & & & & & \\
\hline \multirow{2}{*}{$\begin{array}{l}\text { HUNTING OR FISHING } \\
\text { WATESHED PROTECTION }\end{array}$} & & & & $+t^{\star \star \star}$ & & & & & \\
\hline & & & & $-\star \star \star \star$ & & & & & \\
\hline VISUAL BEAUTY & & & & & & & $t^{\star \star \star}$ & & \\
\hline \multirow{2}{*}{$\begin{array}{l}\text { TIMBER PRODUCTION } \\
\text { FRUIT TREE ORCHARD }\end{array}$} & $t^{\star \star \star}$ & & $+^{*}$ & & & & & & $+^{\star \star \star}$ \\
\hline & & & & & & $+t^{\star \star}$ & & & \\
\hline \multirow{2}{*}{$\begin{array}{l}\text { GINSENG OR MUSHROOMS } \\
\text { LIVESTOCK PASTURE }\end{array}$} & & & & & $++^{\star \star}$ & & & & \\
\hline & & $+{ }^{* \star}$ & & & & $+t^{\star \star \star}$ & & & \\
\hline OTHER USES & & & $++^{\star \star}$ & & & & & & \\
\hline \multicolumn{10}{|l|}{ FOREST ACTIVITY } \\
\hline \multirow{2}{*}{$\begin{array}{l}\text { THINNED TREES } \\
\text { WILDLIFE FOOD CROPS }\end{array}$} & & & & & 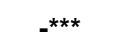 & & & & \\
\hline & & & & $+{ }^{\star \star \star *}$ & & & & $+t^{\star \star \star}$ & \\
\hline \multirow{2}{*}{$\begin{array}{l}\text { IMPROVED SOIL } \\
\text { IMPROVED WATER }\end{array}$} & & & & & & $+^{*}$ & & & \\
\hline & & $+t^{\star \star \star}$ & & & & & & & \\
\hline NON-TIMBER PRODUCTS & & & $+t^{\star \star}$ & & & & & & \\
\hline \multirow{2}{*}{$\begin{array}{l}\text { FOREST HEALTH } \\
\text { LEASED PROPERTY }\end{array}$} & $+t^{\star \star \star}$ & & & & $+t^{\star \star \star}$ & $t^{*}$ & $+t^{\star \star \star}$ & & \\
\hline & $t^{*}$ & & & & & & & & \\
\hline OTHER ACTIVITIES & & & $+{ }^{\star \star \star}$ & & & & & & 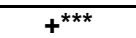 \\
\hline \multirow{3}{*}{$\begin{array}{l}\text { ASSISTING AGENCIES } \\
\text { WVU DIVISION OF FORESTRY } \\
\text { WV DIVISION OF FORESTRY }\end{array}$} & & & & & & & & & \\
\hline & & & & $+{ }^{\star \star}$ & & & & & \\
\hline & $+^{\star \star \star}$ & $t^{\star \star \star}$ & $+^{\star \star \star}$ & $+{ }^{\star \star \star}$ & $+^{\star \star \star}$ & $+^{\star \star \star}$ & $+t^{\star \star \star}$ & 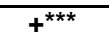 & 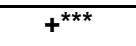 \\
\hline Significant Variables & 6 & 4 & 7 & 9 & 7 & 7 & 3 & 4 & 4 \\
\hline Respondents: Yes $=1$ & 252 & 245 & 238 & 235 & 232 & 225 & 224 & 193 & 192 \\
\hline Respondents: Total & 451 & 451 & 451 & 451 & 451 & 451 & 451 & 451 & 451 \\
\hline $\mathrm{Chi}^{2}$ Value (df) & $85.8(6)$ & $52.7(4)$ & $89.8(7)$ & $120.1(9)$ & $39.4(7)$ & $54.9(7)$ & $66.3(3)$ & $56.8(4)$ & $95.2(4)$ \\
\hline Odds Ratio & $4.9: 1$ & 3.3:1 & $4.6: 1$ & $5.9: 1$ & $3.9: 1$ & $3.3: 1$ & $3.1: 1$ & $3.6: 1$ & $4.5: 1$ \\
\hline
\end{tabular}

(vi.) Soil Resources:

More recent forest owners with higher incomes who use their property for a fruit tree orchard and livestock pasturage tended to be more interested in soil fertility and erosion control issues. They also tend to implement forest protection and soil improvement practices within their forest property. Additionally, the WV State Division of Forestry was the public agency that 
respondents interested in soil resource issues tended to use in the past for obtaining management assistance. The relationship between these characteristics suggests that these landowners do acknowledge their need for soil management, which is important for them to successfully achieve their ownership and management objectives (Table 5). This was also evident during property visits with NIPF owners who showed a concern for and interest in soil resources including fertility and erosion control issues (Magill, 2000).

(vii.) Visual Beauty:

Landowners owning forest property for visual enjoyment and protecting its health tend to be interested in improving and managing visual resources. They also tend to have received assistance in the past from the WV State Division of Forestry. The positive relationship between these characteristics for this group of landowners suggest that they do realize the need to protect the visual forest resources of their property from fire, disease, insects and poor timber harvest practices, but they also recognize a need for assistance (Table 5). Property visits and discussions with NIPF owners also revealed an interested in protecting and maintaining visual resources (Magill, 2000).

(viii.) Dendrology and Silvics:

Landowners interested in dendrology issues tend be more recent owners that own their forest property for investment. They were also more likely to establish wildlife food crops on their property and tend to have received assistance in the past from the WV State Division of Forestry. The positive relationship between these characteristics indicates an understanding by this group of landowners that the valuation and success of a forest investment often depends on the ability to correctly identify and know the growth requirements of forest plants, especially tree and shrub species (Table 5). Forest plant identification and reproduction issues were also highlighted conversation topics during visits with NIPF owners who wanted to learn more about this assistance topic (Magill, 2000). 
(ix.) Valuation of Timber or Forestland:

Timber or forestland valuation assistance tended to be requested by landowners using their forest property for investment and timber production. Building fence (other activities) was a management practice that landowners interested in valuation assistance were more likely to implement on their property. In addition, landowners interested in valuation issues tend to have received help in the past from the WV State Division of Forestry. The positive relationship between these characteristics suggests that this group of landowners realize that proper valuation and protection of their forest assets (land or timber) can be complicated and often requires professional assistance (Table 5). During visits with NIPF owners, valuation issues were topics of conversation that most of the landowners were unsure about, but they were quite interested in getting help to better understand valuation principles (Magill, 2000).

\section{Summarizing the Reduced Logistic Analysis}

The landowners requesting these preferred assistance topics appear to understand that their reasons for ownership and activities they engage in on their property (Table 5) can be biologically and economically complicated. Proper identification of forest plants is critical for successful implementation of most forestland uses and management. Using forest property for investment can revolve around timber production, non-timber products (ginseng etc.), wildlife habitat or visual beauty and identifying valuable forest plant species is crucial for proper valuation assessment. Landowners interested in dendrology were more likely own their property for investment and tend to plant wildlife food crops on their property.

Utilizing silviculture to conduct proper management depends on knowing the growth and reproductive traits of trees and other forest plants as well as site factors such as soil and water resources. Respondents interested in silviculture and valuation issues tend to use their property for investment and timber production. Landowners interested in silviculture were also more likely to grow and harvest non-timber products (ginseng etc.), as were those with liability concerns (Table 5). 
Forest protection and plant identification issues are critical for maintaining timber and non-timber plant species, wildlife habitats and food sources, hunting or fishing activities, watershed quality, soil fertility and visual resources. Implementing forest health improvements were characteristic of landowners inclined to be interested in forest health, liability, visual beauty and soil resource issues. Respondents interested in forest health issues also tend to own their property for timber production, as do landowners requesting silviculture and valuation assistance. Visual enjoyment of forest property tended to be a use engaged in by those interested in visual management issues.

Landowners interested in wildlife habitat improvement issues were more likely to establish wildlife food crops and use their property for residence and hunting or fishing while also being similar to respondents wanting forest health assistance in that they own their property for wildlife habitat. The negative relationship of watershed protection with requests for wildlife habitat assistance suggests that this group of landowners would like assistance to manage wildlife without disrupting watershed quality. Using property for livestock or a fruit tree orchard requires knowledge of soil and water properties. Livestock grazing often causes soil compaction resulting in a negative impact on ground water resources, which limits plant growth. Respondents interested in water resource issues tend to conduct water improvement practices and use their property for livestock grazing, which was synonymous with landowners wanting soil resource assistance. Soil resource assistance was also more likely to be requested by those conducting soil improvement practices and using their property for a fruit tree orchard.

Leasing forest property for timber or recreation and protecting visual resources often depends on the establishment, maintenance, protection and valuation of trees and other forest plants, wildlife habitat, soil fertility and water quality. Landowners requesting forest protection assistance tend to lease their property for timber or recreation. Tree thinnings were a significant activity for requests of liability assistance, but they were negatively correlated, which seems to suggest that these respondents want assistance to better understand the legalities before implementing such a practice. Landowners interested in liability issues were also more likely to use their property for investment. 
Conducting silviculture practices, protecting forest resources and leasing property are liability concerns for NIPF owners, because of the responsibility the landowner may have to persons using their property for economic of recreational benefit. Keeping the property free of hazards is a way to reduce landowner liability (Allen et al., 1997). Other liability issues include owning forest property for investment and timber production as well as for growing non-timber products (ginseng, mushrooms etc.), which often involve trespassing. Constructing fences around property is one way to protect these assets. Landowners interested in silviculture and valuation issues tend to built fences on their property. Property rights and taxes are also concerns for landowners, especially if they get involved in assistance or management programs (McEvoy, 1998).

More recent forest ownership and higher incomes as well as previously receiving assistance from the WV State Division of Forestry were also consistent factors in the models for landowners requesting the nine preferred assistance topics. The WVU Division of Forestry tended to have provided assistance in the past to landowners interested in wildlife management issues (Table 5).

\section{Comparing NIPF Respondents in West Virginia to those in Idaho and Indiana}

Years of forest ownership and income were the only two significant socioeconomic characteristics in the logistic models for West Virginia NIPF respondents interested in the nine preferred assistance topics (Table 5). The significance of these two factors follows a similar pattern to surveys conducted in Indiana (Mills et al., 1996) and Idaho (Grasser \& Force, 1996). These studies concluded that NIPF owner's of more recent forest ownership and higher incomes tend to become more interested and involved in managing their forest resources.

The 451 landowners responding in the West Virginia study that preferred the nine assistance topics indicated more commercial (timber production, investment, livestock pasture and fruit orchard) than non-commercial (wildlife habitat, visual beauty, residence and hunting or fishing) reasons for owning forest property in the logistic models (Table 5). In contrast, the Indiana study concluded that NIPF owners tend to own their property for more non-commercial 
reasons whether or not they participated in a forestry assistance program. Conversely, the West Virginia respondents tended to conduct an equal number of commercial (tree thinnings, soil improvements, leases, fencing and ginseng etc.) and non-commercial (wildlife food plots, water improvements, forest health) forestry practices within their property. This pattern was similar to NIPF owners from Indiana who participated in assistance programs (Mills et al., 1996).

\section{Recommendations and Conclusion}

Although landowners responding in this study are known to have previously received assistance, they still expressed a great deal of interest in obtaining assistance to manage their forest property (Table 5). This high level of desire for assistance could act as a catalyst to increase the involvement of public and private organizations in developing and providing forest management programs. The topics of interest for these landowners are varied and ranged from protecting forest health and soil and water resources to the valuation of timber and forestland. Other specific topics requested were plant identification and growth requirement issues, wildlife and visual resource management as well as growing, thinning and harvesting trees or other forest plants. These forest owners also expressed an interest in learning more about legal ownership issues such as landowner liability, property rights and taxes. It would appear that this group of NIPF owners are interested in sustaining their forest resources while simultaneously using and improving the resources for amenity, quality of life and income benefits (Table 5).

In the past, the low participation rate of landowners in assistance programs may have been due to the limited scope of topics offered. Perhaps offering programs that enable landowners to better achieve their management objectives would increase the participation rate. Even though a higher income level and more recent forest ownership were consistent characteristics for landowners requesting several of the survey topics (Table 5), audiences for assistance programs should not be limited to owners with these qualities. In fact, these constitute only a portion of the NIPF owners in West Virginia. The challenge is to devise methods for engaging all NIPF owners in programs that result in better resource management. 
The results of this study (Table 5) also revealed the West Virginia State Division of Forestry to be the lead agency for providing assistance to landowners. Perhaps landowners used this agency to a greater extent, because it is more visible and available. However, the low rate of landowner participation in programs may be a reflection that this state agency's ability to provide services to NIPF owners is compromised by its regulatory responsibilities such as enforcing BMP regulations. This is not a negative reflection on the State Division of Forestry; the fact is they lack the resources to improve management on 256,500 NIPF ownership's alone (Table 1). Based on the logistic results, when considering all factors tested in the models, only those requesting wildlife management assistance indicated the West Virginia University Division of Forestry as being instrumental in providing assistance. Furthermore, the West Virginia University Extension Service was not revealed in the regression models as a means of delivery for landowners interested in any of assistance topics analyzed (Table 5). Perhaps having a wildlife extension specialist on staff is the reason why landowners interested in wildlife management issues tended to receive assistance from the West Virginia University Division of Forestry. Therefore, it is suggested that to increase interest in forest management programs the WVU Division of Forestry and Extension Service need to increase their visibility and availability to NIPF owners. Increasing the number of visits to NIPF properties by resource professionals and improving interagency cooperation as well as clarifying property rights and tax issues are also suggested for improving landowner interest and participation. Using financial incentives to promote sustainability and stewardship should be cautiously considered, because before landowners can use these incentives they must first understand good forest management practices (Magill et al., 2000). Improving resource management on private forestland is especially important to West Virginia, which is heavily forested and where $80 \%$ of this forestland is controlled by private landowners. In addition, the future ecological, economic and social well being of the state and its residents may very well depend on the sustainable management of forest resources (Magill et al., 2000). The results of this survey can be used to target landowners for specific topics as well as gear workshops or programs that reflect the objectives of these landowners while simultaneously fostering owners who are better informed regarding forest management practices. 
Even though the results of this study are interesting, there are different types of assistance landowner's need, which may require exploring a variety of possibilities. Perhaps the greatest challenge is to find ways to engage the non-participant populations in resource management assistance programs. The results of this study identifies populations who do participate, and by elimination, those who do not. Programs that appeal to low-income and older owners is a particular challenge that must be met in order to achieve good management on the broad land base in West Virginia.

In this study, NIPF owners that were interviewed who actively manage their property tended to have originally lived in a rural area, moved to a more urban environment and then returned to the land by purchasing forest property. They were also more likely to be middle age with higher than average incomes and have a high school education. Results of correlation analysis of socioeconomic factors for the entire sample population did not reveal a significant relationship between income and education level. However, both income and education level were significantly and positively associated with age of the respondents.

Delivery of programs that meet the interests and needs of the landowner as well as propagate sound management practices may require a variety of distribution mechanism and in different combinations, which is the subject of future study. Perhaps the computer inter-net could be used as a distance learning tool to provide more information access. In addition, using visual training mechanisms like the Stand Visualization System (appendix N) may allow landowners to make better management choices before forestry practices are conducted (Magill, 2000). 


\section{Appendix A}

Questionnaire: Please answer questions by following the directions. It should take approximately 20 to 30 minutes to complete the questionnaire.

To Answer question 1, please write down the total number of forested acres for each property you own and the number of years owned as well as in which West Virginia County the property is located. In addition, for each parcel of property, please check mark how you got the property (Bought, Other or Inherited) and how the property is owned (Singly, Jointly or Other).

Question 1.

Property Numbers

\begin{tabular}{|c|c|c|c|c|c|c|}
\hline & & Property 1 & Property 2 & Property 3 & Property 4 & Property 5 \\
\hline & Total Forested Acres & & & & & \\
\hline & Years Owned & & & & & \\
\hline & WV County Location & & & & & \\
\hline \multirow{6}{*}{$\begin{array}{l}\text { CHECK } \\
\text { ALL } \\
\text { THAT } \\
\text { APPLY }\end{array}$} & Bought & & & & & \\
\hline & Other & & & & & \\
\hline & Inherited & & & & & \\
\hline & Singly & & & & & \\
\hline & Jointly & & & & & \\
\hline & Other & & & & & \\
\hline
\end{tabular}

To answer question 2, please write down the appropriate answers on the underlined blank spaces.

2. I permanently live in

and

and

3. Please identify each of the uses of your forested property that are important to you, by circling ONE CHOICE for each of your forest property uses.

Property Uses

Most Important

\begin{tabular}{|llllll|}
\hline As a Place to live & 1 & 2 & 3 & 4 & 5 \\
\hline As an Investment & 1 & 2 & 3 & 4 & 5 \\
\hline For Wildlife Habitat & 1 & 2 & 3 & 4 & 5 \\
\hline For Hunting or Fishing & 1 & 2 & 3 & 4 & 5 \\
\hline For Watershed Protection & 1 & 2 & 3 & 4 & 5 \\
\hline For Visual Beauty & 1 & 2 & 3 & 4 & 5 \\
\hline For Hiking or Biking & 1 & 2 & 3 & 4 & 5 \\
\hline For Timber Production & 1 & 2 & 3 & 4 & 5 \\
\hline For a Christmas Tree Farm & 1 & 2 & 3 & 4 & 5 \\
\hline As a Fruit Tree Orchard & 1 & 2 & 3 & 4 & 5 \\
\hline For Ginseng or Mushroom Production & 1 & 2 & 3 & 4 & 5 \\
\hline For Livestock Pasture & 1 & 2 & 3 & 4 & 5 \\
\hline For Firewood or Fence Posts & 1 & 2 & 3 & 4 & 5 \\
\hline For Maple Syrup Production & 1 & 2 & 3 & 4 & 5 \\
\hline For Other Purposes & 1 & 2 & 3 & 4 & 5 \\
\hline
\end{tabular}




\section{Before continuing to answer the questions, please read the following definition of forest management.}

Forest management includes any activity or recommendation to use, improve or maintain forest resources within a forested property. Forest resources include timber or trees, wildlife, recreation, visual beauty, soil, water (streams and ponds) and other plants (herbs \& mushrooms).

To answer question 4, please refer to the definition of Forest Management given above.

4. In the last 15 years, have any forest resources been managed within any of your forested property?

\section{CHECK ONE CHOICE ONLY}

Yes $\quad$ No

To answer question 5, please identify if you have done any of the following forest management activities to use, improve, or maintain forest resources within your forested property in the last 15 years.

CHECK ALL THAT APPLY

5. I have Harvested Timber

I have___ Used a Forester to Oversee the Most Recent Timber Harvest on My Property

I was_____ Satisfied With the Condition of My Property after the last Timber Harvest

I was____ Not Satisfied With the Condition of My Property after the last Timber harvest

I plan__ To Have Timber Harvested on My Property in the Next 5 Years

I have____Planted Trees (includes Christmas Trees and Shrubs)

I have___ Thinned Trees

I have___ Cut Grapevines or Other Vines and Plants

I have___ Improved or Maintained Visual Beauty

I have___ Constructed or Maintained Trails

I have___ Constructed or Maintained Access Roads

I have___ Planted Wildlife Food Crops

I have___ Improved Soil Fertilty or Controlled Soil Erosion

I have___ Improved Water Quality or Quantity (springs, streams, ponds, or watersheds)

I have___ Planted or Harvested Other Forest Plants (mushrooms, ginseng or other herbs)

I have___Had My Property Boundaries Surveyed

I have___ Controlled Forest Damaging Agents (fire, disease, insects, deer or plants)

I have____Leased My Property for Timber Production, Hunting or Other Recreation Activities

I have___Done Other Forest Management Activities: Please List 
To answer question 6, please check mark how important forest management is to you. CHECK ONE CHOICE ONLY

6. As a forest landowner, forest management is Very Important to me.

As a forest landowner, forest management is Important to me.

As a forest landowner, forest management is Some What Important to me.

As a forest landowner, forest management is Not Important to me.

7. If you have not done anything to use, improve, or maintain forest resources within your forested property, would you like to in the near future?

Check One Choice Only Yes No

Does Not Apply

8. Do you currently have a written forest management plan for any of your forested property?

\section{CHECK ONE CHOICE ONLY}

Yes ANSWER Q9 AND CONTINUE

No GO TO Q10 AND CONTINUE

To answer question 9, please identify the number of the properties you listed in QUESTION 1 that have written forest management plans, by placing a check mark under the correct choices. In addition, please write down the total number of acres that are covered by a written forest management plan for each of the properties you have listed.

9. How many of your forested properties do you have written management plans for?

\section{Property Numbers}

\begin{tabular}{|l|l|l|l|l|l|}
\hline & Property 1 & Property 2 & Property 3 & Property 4 & Property 5 \\
\hline CHECK ALL THAT APPLY & & & & & \\
\hline Total Management Plan Acres & & & & & \\
\hline
\end{tabular}

10. If you do not have written forest management plans, would you like to have a plan in the near future?

CHECK ONE CHOICE ONLY Yes No

Does Not Apply 


\section{Before continuing to answer the questions, please read the following definition of forest management assistance.}

Forest management assistance can include any informational, financial or technical training and assistance that is provided by any forestry organization, agency, company or forest resource professional. Forest resource professionals can include foresters, wildlife biologists, county extension agent's etc.

11. In the last 15 years, have you received forest management assistance?

CHECK ONE CHOICE ONLY Yes ANSWER Q12 THROUGH 14 AND CONTINUE No GO TO Q15 ON THE NEXT PAGE AND CONTINUE

12. In the last 15 years, what types of forest management assistance have you received?

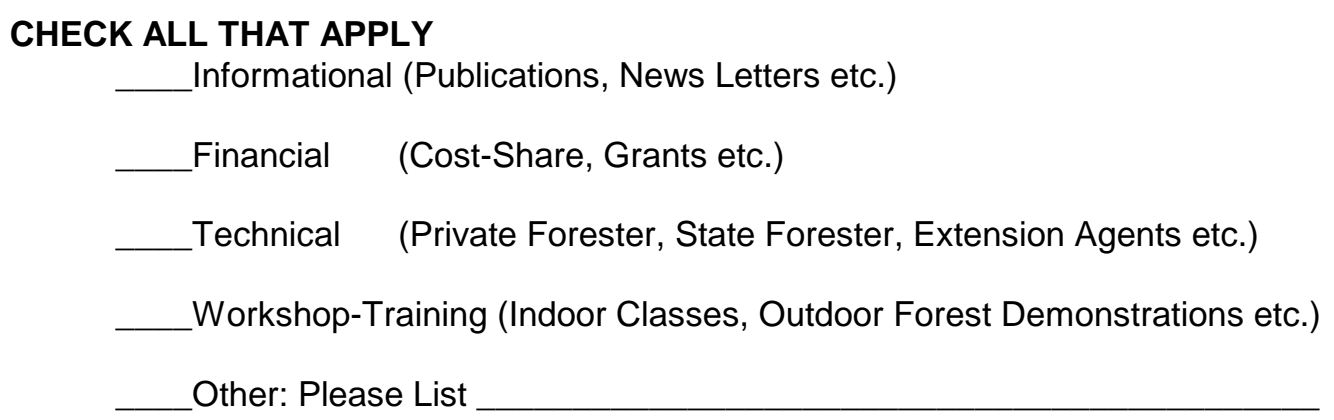

13. In the last 15 years, which of the following organizations or agencies provided you with forest management assistance?

CHECK ALL THAT APPLY

West Virginia University Division of Forestry

I have received assistance from the I have received assistance from the I have received assistance from the West Virginia University Extension Service

I have received assistance from the I have received assistance from the I have received assistance from the I have received assistance from the I have received assistance from the I have received assistance from the I have received assistance from the I have received assistance from the I have received assistance from $A$ I have received assistance from $A$ I have received assistance from West Virginia Division of Forestry (County Forester) West Virginia Department of Agriculture West Virginia Department of Natural Resources West Virginia Forestry Association West Virginia Woodlands Owners Association West Virginia Tree Farm Program USDA Forest Service USDA Farm Service Agency USDA Natural Resources Conservation Service Timber Company Private Consulting Forester Other Sources: Please List

14. How satisfied were you with the forest management assistance you received? CHECK ONE CHOICE ONLY

I was_ Very Satisfied with the assistance I received
I was_ Some What Satisfied with the assistance I received
I was_ Some What Dis-Satisfied with the assistance I received
I was_ Not Satisfied with the assistance I received


15. Please identify whether or not you would like Forest Management Assistance for any of the Forestry topics that are listed on the next 2 pages. You can chose more than one type of assistance for any Forestry topics listed by check marking all of the types of assistance you would like. See Question 12 for Definitions of Assistance Types on Page 4.

\section{For Example: Would you like assistance To Improve or Manage Wildlife Habitat? Yes No \\ If yes, would you like (_Workshop-Training), (_ Financial), (_Technical) Assistance \\ By check marking Workshop-Training and Financial, you have identified that you would like Workshop-Training and Financial Assistance to Improve or Manage Wildlife Habitat.}

\section{Would you like Forest Management Assistance For Thinning or Harvesting Trees or Other Forest Plants? Yes No}

If yes, would you like (_Workshop-Training), (_ Financial), (_r Technical) Assistance

Would you like assistance To Identify or Grow Trees or Other Forest Plants? Yes No

If yes, would you like (_Workshop-Training), (_ Financial), (_ Technical) Assistance

Would you like assistance To Improve or Manage Wildlife Habitat?

Yes $\quad$ No

If yes, would you like (_Workshop-Training), (_ Financial), (_ Technical) Assistance

Would you like assistance To Develop Forest Recreational Opportunities or Uses (Hunting, Fishing, Hiking, Biking)? Yes No

If yes, would you like (_Workshop-Training), (_ Financial), (_ Technical) Assistance

Would you like assistance To Improve Water Quality or Quantity from Springs, Streams, Ponds or Watersheds? Yes No

If yes, would you like (_Workshop-Training $),($ Financial $),($ Technical $)$ Assistance

Would you like assistance To Improve Soil Fertility or Control Soil Erosion?

Yes

No

If yes, would you like (_Workshop-Training), (_ Financial), (_ Technical) Assistance

Would you like assistance For Valuing or Selling Timber or Forest Land?

Yes No

If yes, would you like (_Workshop-Training), (_ Financial), (_ Technical) Assistance 


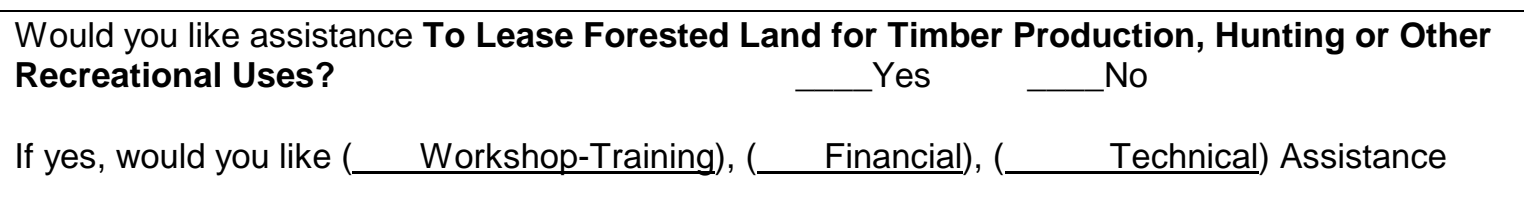

Would you like assistance for Dealing with Landowner Liability, Property Rights or Taxes?
If yes, would you like (__ Workshop-Training $),(\quad$ Financial $),(+$ Technical $)$ Assistance
Would you like assistance For the Cooperative Management of Forest Land by Neighboring Landowners? Yes No
If yes, would you like (_Workshop-Training), (_Financial $),(\quad$ Technical $)$ Assistance

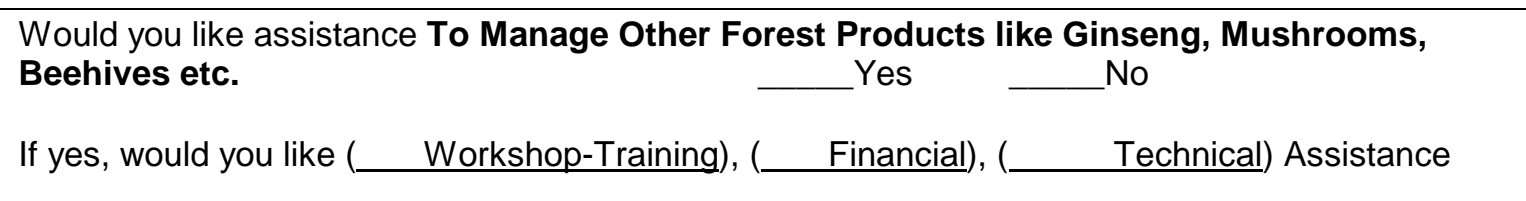

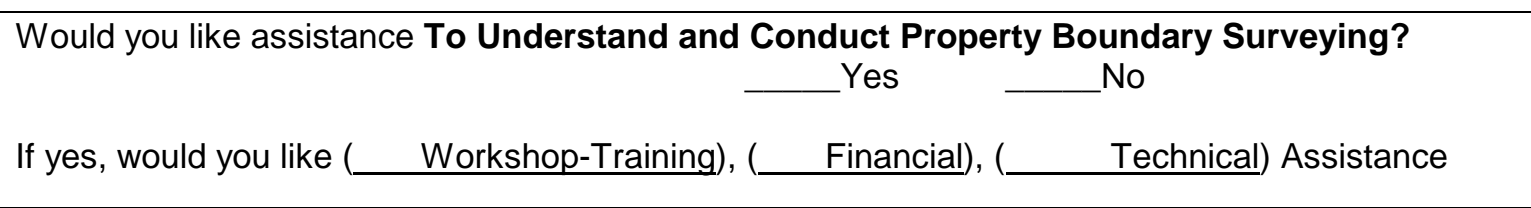

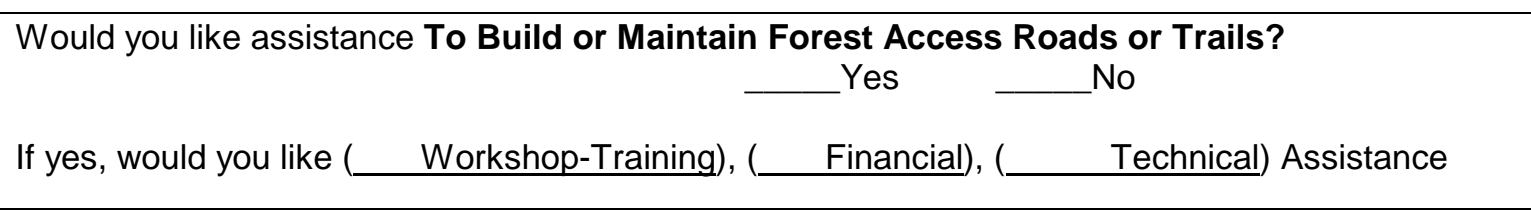

\begin{tabular}{|c|c|c|}
\hline \multicolumn{3}{|c|}{$\begin{array}{l}\text { Would you like assistance To Control or Prevent Forest Damage by Fire, Disease, Insects, } \\
\text { Deer or Other Causes? }\end{array}$} \\
\hline f yes, would you like ( & Workshop-Training), ( & Technical) Assistance \\
\hline
\end{tabular}
Would you like assistance To Improve or Maintain Visual Beauty? Yes $\quad$ No
If yes, would you like (_ Workshop-Training $),($ Financial $),(\quad$ Technical $)$ Assistance

To answer question 16, write down the correct number on the lines to the right of the question.

$\begin{array}{ll}\text { 16. What is your birth date? } & \text { Month and__ Year } \\ \text { 17. What is your gender? } & \mathrm{I} \text { am__ Male }\end{array}$


18. What is your marital status? CHECK ONE CHOICE ONLY

I am_Narried
I was_Never Married
I am__Widowed
I am__Divorced
I am__Separated

19. What is your annual household income?

Our Income is less than $\$ 10,000$

Our Income is less than $\$ 20,000$

Our Income is less than $\$ 30,000$

Our Income is less than $\$ 40,000$

Our Income is $\$ 40,000$ or more

or more

CHECK ONE CHOICE ONLY

20. What is the highest level of education you have completed?

\begin{tabular}{|c|c|}
\hline I did not Attend & High School \\
\hline I have Attended & High School \\
\hline I am a & High School Graduate or Equivalent (GED) \\
\hline I have Attended & College \\
\hline I am an & Associate Degree Graduate \\
\hline $\mathrm{I} a \mathrm{am}$ & Bachelor Degree Graduate \\
\hline I have Attended & Graduate School \\
\hline I am a & Master's Degree Graduate \\
\hline I have done & Graduate Study Beyond Master's Requirements \\
\hline I am a & PhD. or Professional Degree Graduate \\
\hline
\end{tabular}

21. What is your current employment status?

\section{CHECK ALL THAT APPLY}

Work 35 Hours or More per Week
Work Less Than 35 Hours per Week
I am_ Self Employed
I am_ Seasonally Employed
I am $\quad$ Sot Working, but Currently Looking for Work
I am_ Student Enrolled at an Educational Institution
I am_Detired and Receiving a Pension

22. How many hours each month do you spend managing your forested property?

23. How many hours each month do you need to best manage your forested property?

Once you have completed the questionnaire, we invite you to tell us in writing whether or not this questionnaire was adequate for this topic and provide additional comments and suggestions.

Thank you for your time and cooperation in filling out the questionnaire.

Sincerely yours,

Daniel J. Magill, M.Sc. Forestry Student, WVU Division of Forestry 


\section{Appendix B-1}

Table 1-1: Independent Demographic Variable Categories and Codes

\begin{tabular}{|c|c|c|c|c|c|}
\hline Variable & LANDSIZE & TENRGRUP & INCOME & AGEGROUP & EDUCATIO \\
\hline Characteristics & $\begin{array}{l}\text { Landsize } \\
\text { Acres }\end{array}$ & $\begin{array}{l}\text { Tenure } \\
\text { Years }\end{array}$ & $\begin{array}{l}\text { Income } \\
\text { Annual }\end{array}$ & $\begin{array}{l}\text { Age } \\
\text { Years }\end{array}$ & $\begin{array}{c}\text { Education } \\
\text { Level }\end{array}$ \\
\hline Measurements & 3 Categories & 3 Categories & 5 Categories & 4 Categories & 9 Categories \\
\hline Codes & $\begin{array}{l}\text { 2. } 10-99 \mathrm{ac} \\
\text { 3. } 100-199 \mathrm{ac} \\
\text { 4. } 200-299 \mathrm{ac}\end{array}$ & $\begin{array}{l}\text { 1. } 1-10 y r s \\
\text { 2. } 11-20 y r s \\
\text { 3. } 21+y r s\end{array}$ & $\begin{array}{l}\text { 1. }<\$ 10,000 \\
\text { 2. }<\$ 20,000 \\
\text { 3. }<\$ 30,000 \\
\text { 4. }<\$ 40,000 \\
\text { 5. } \$ 40,000+\end{array}$ & $\begin{array}{l}\text { 1. }<25 \\
\text { 2. } 26-49 \\
3.50-64 \\
\text { 4. } 65+\end{array}$ & $\begin{array}{l}\text { 1. No High School } \\
\text { 2. High School } \\
\text { 3. High School Grad. } \\
\text { 4. Attended College } \\
\text { 5. Associate Degree }\end{array}$ \\
\hline & & & & & $\begin{array}{l}\text { 6. Bachelor Degree } \\
\text { 7. Graduate School } \\
\text { 8. Master's Degree } \\
\text { 9. Post Master's } \\
\text { 10. PhD. Graduate }\end{array}$ \\
\hline
\end{tabular}

Table 1-2: Landowners Property Uses

\begin{tabular}{|c|c|c|c|c|c|c|}
\hline \multirow[t]{3}{*}{ Variable } & \multirow[t]{3}{*}{ Property Use } & \multicolumn{5}{|c|}{ Measurement Ranking 1-5 } \\
\hline & & \multicolumn{2}{|c|}{ Most Important } & \multirow{2}{*}{$\frac{\text { Important }}{3}$} & \multicolumn{2}{|c|}{ Least Important } \\
\hline & & 1 & 2 & & 4 & 5 \\
\hline PLACLIV2 & Residence & & & & & \\
\hline INVESTM2 & Investment & & & & & \\
\hline WILDLIF2 & Wildlife Habitat & & & & & \\
\hline HUNTFIS2 & Hunting or Fishing & & & & & \\
\hline WATESHD2 & Watershed Protection & & & & & \\
\hline VISULBU2 & Visual Beauty & & & & & \\
\hline HIKBIKE2 & Hiking or Biking & & & & & \\
\hline TIMBERP2 & Timber Production & & & & & \\
\hline XMASTRE2 & Christmas Tree Farm & & & & & \\
\hline FRUITRE2 & Fruit Tree Orchard & & & & & \\
\hline GINSENG2 & Ginseng or Mushrooms Production & & & & & \\
\hline LIVSTOC2 & Livestock Pasture & & & & & \\
\hline FIREWOD2 & Firewood or Fence Posts & & & & & \\
\hline MAPLSYR2 & Maple Syrup Production & & & & & \\
\hline OTHRUSE2 & Other Uses & & & & & \\
\hline
\end{tabular}


Appendix B-2

Table 1-3: Forestry Activities Conducted on Landowners Property \& Assisting

Agencies

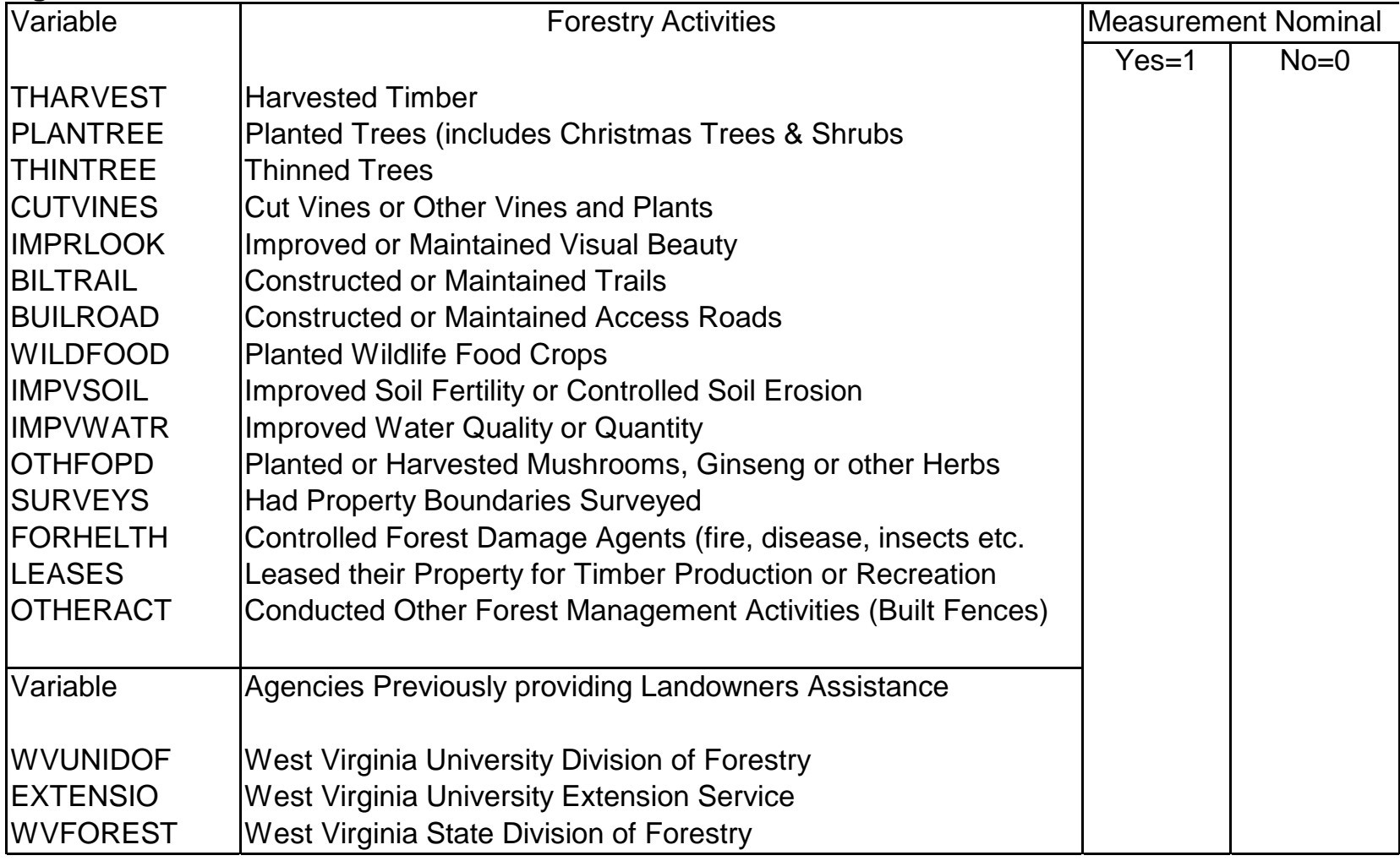




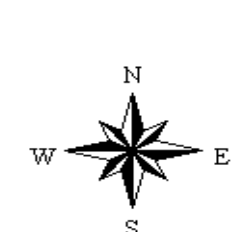

Figure 1: West Virginia NIPF Sample Regions and Counties by Percent Forest Cover

$\begin{array}{lllll}10 & 0 & 10 & 20 & \text { Miles }\end{array}$

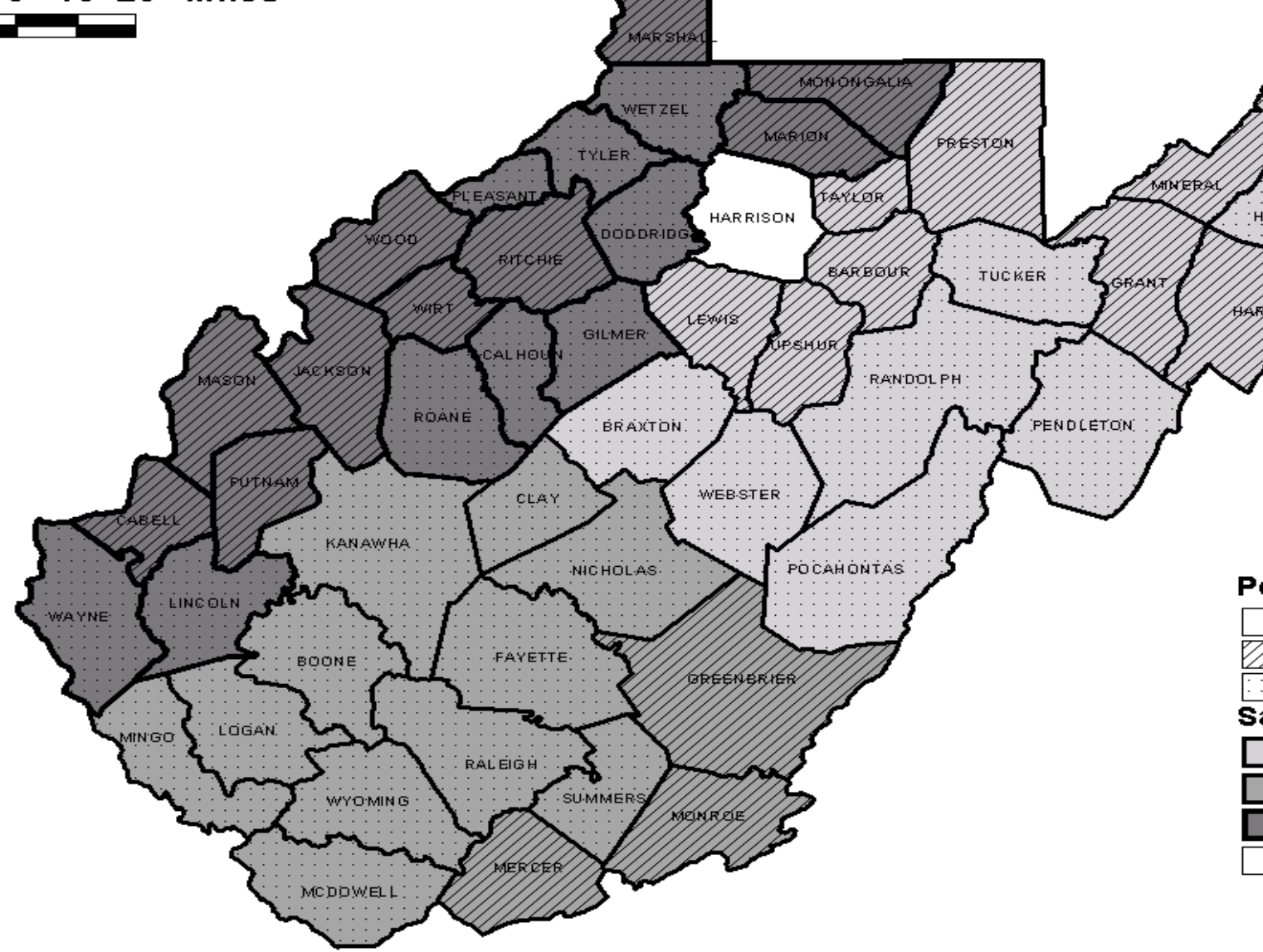

Percent Forest Cover

$$
\begin{aligned}
& <60 \% \\
& 60-79 \%
\end{aligned}
$$$$
80+\%
$$

Sample Regions.

$$
\begin{aligned}
& \text { Northeastern } \\
& \text { Southern } \\
& \text { Northwestern } \\
& \text { No Samples }
\end{aligned}
$$




\section{Appendix D-1}

Table 1-1: Breakdown of 451 Responses, by First Property Owned and Percent Forest Cover Region 1: Northeastern. $n=175$

\begin{tabular}{|c|c|c|c|c|c|c|c|c|}
\hline \multirow{3}{*}{$\begin{array}{l}\text { Ownership } \\
\text { (Acres) }=A_{i}\end{array}$} & \multicolumn{3}{|c|}{ Total Number of Owners Sampled } & & \multicolumn{2}{|c|}{ Number of Returns } & \multirow{3}{*}{ Number } & \multirow{3}{*}{$\begin{array}{l}\text { Percent } \\
\text { Returned }\end{array}$} \\
\hline & \multicolumn{2}{|c|}{ Percent County in Forest Cover } & \multirow{2}{*}{$\begin{array}{c}\text { Total Number } \\
\text { Sampled }\end{array}$} & \multirow{2}{*}{$\begin{array}{l}\text { Percent } \\
\text { Sampled }\end{array}$} & \multicolumn{2}{|c|}{ Percent County in Forest Cover } & & \\
\hline & Heavy: $80+\%$ & Moderate: $60-79 \%$ & & & Heavy: $80+\%$ & Moderate: $60-79 \%$ & & \\
\hline \multirow[b]{2}{*}{10 to 99} & \multirow[b]{2}{*}{167} & \multirow[b]{2}{*}{172} & \multirow[b]{2}{*}{339} & \multirow[b]{2}{*}{$85 \%$} & Observed: $\mathrm{O}_{\mathrm{i}}$ & Observed: $\mathrm{O}_{\mathrm{i}}$ & Observed: $\mathrm{O}_{\mathrm{i}}$ & \multirow[b]{2}{*}{$82 \%$} \\
\hline & & & & & 69 & 75 & 144 & \\
\hline \multirow[t]{2}{*}{100 to 199} & 22 & 22 & \multirow[t]{2}{*}{44} & \multirow{3}{*}{$\begin{array}{l}11 \% \\
4 \%\end{array}$} & 10 & 11 & 21 & \multirow{3}{*}{$\begin{array}{l}12 \% \\
6 \%\end{array}$} \\
\hline & 8 & 8 & & & 5 & 5 & 10 & \\
\hline Totals 3 & 197 & 202 & 399 & & 84 & 91 & 175 & \\
\hline Total Percent & $49 \%$ & $51 \%$ & & $100 \%$ & $48 \%$ & $52 \%$ & & $100 \%$ \\
\hline
\end{tabular}

Table 1-2: $\quad$ Percent County in Forest Cover

\begin{tabular}{|c|c|c|c|c|c|c|}
\hline \multirow{2}{*}{$\begin{array}{l}\text { Ownership } \\
\text { (Acres) }=e_{i}\end{array}$} & \multirow{2}{*}{$\begin{array}{r}\text { Heavy: } 80+\% \\
\text { Expected } \mathrm{e}_{\mathrm{i}}\end{array}$} & \multirow{2}{*}{$\frac{\text { Moderate: } 60-79 \%}{\text { Expected } \mathrm{e}_{\mathrm{i}}}$} & \multirow{2}{*}{$\begin{array}{c}\text { Total } \\
\text { Expected } \mathrm{e}_{\mathrm{i}}\end{array}$} & \multirow[b]{2}{*}{$\left(o_{i}-e_{i}\right)$} & \multirow[b]{2}{*}{$\left(o_{i}-e_{i}\right)^{2}$} & \multirow[b]{2}{*}{$\left(o_{i}-e_{i}\right)^{2} / e_{i}$} \\
\hline & & & & & & \\
\hline 10 to 99 & 73 & 76 & 149 & -5 & 25 & 0.1678 \\
\hline 100 to 199 & 9 & 10 & 19 & 2 & 4 & 0.2105 \\
\hline 200 to 299 & 3 & 4 & 7 & 3 & 9 & 1.2857 \\
\hline Totals 3 & 85 & 90 & 175 & & ${ }^{2}$ Statisti & 1.664 \\
\hline
\end{tabular}

$\mathrm{K}=3$ categories

Degrees of Freedom $=2$

Reject Ho: if CHI2 > 9.210 @ Alpha 0.01 and 2 Degrees of Freedom

$1.664<9.210$

Do not Reject Ho: because there is no significant difference between the observed and expected number of landowners responding in the three acreage and two cover types sampled for the Northeastern region of WV. 


\section{Appendix D-2}

Table 2-1: Breakdown of 451 Responses, by First Property Owned and Percent Forest Cover Region 2: Southern. $n=115$

\begin{tabular}{|c|c|c|c|c|c|c|c|c|}
\hline \multirow{3}{*}{$\begin{array}{l}\text { Ownership } \\
\text { (Acres) }=A_{i}\end{array}$} & \multicolumn{3}{|c|}{ Total Number of Owners Sampled } & & \multicolumn{2}{|c|}{ Number of Returns } & \multirow[b]{2}{*}{ Number } & \multirow{3}{*}{$\begin{array}{l}\text { Percent } \\
\text { Returned }\end{array}$} \\
\hline & \multicolumn{2}{|c|}{ Percent County in Forest Cover } & \multirow{2}{*}{$\begin{array}{c}\text { Total Number } \\
\text { Sampled }\end{array}$} & \multirow{2}{*}{$\begin{array}{l}\text { Percent } \\
\text { Sampled }\end{array}$} & \multicolumn{2}{|c|}{ Percent County in Forest Cover } & & \\
\hline & Heavy: $80+\%$ & Moderate: $60-79 \%$ & & & Heavy: $80+\%$ & Moderate: $60-79 \%$ & Returned & \\
\hline \multirow[b]{2}{*}{10 to 99} & & & \multirow[b]{2}{*}{251} & \multirow[b]{2}{*}{$85 \%$} & Observed: $\mathrm{O}_{\mathrm{i}}$ & Observed: $\mathrm{O}_{\mathrm{i}}$ & Observed: $\mathrm{o}_{\mathrm{i}}$ & \multirow[b]{2}{*}{$79 \%$} \\
\hline & 188 & 63 & & & 65 & 26 & 91 & \\
\hline 100 to 199 & 24 & 8 & 32 & $11 \%$ & 12 & 5 & 17 & $15 \%$ \\
\hline 200 to 299 & 9 & 3 & 12 & \multirow[t]{2}{*}{$4 \%$} & 5 & 2 & 7 & \multirow[t]{2}{*}{$6 \%$} \\
\hline Totals 3 & 221 & 74 & 295 & & 82 & 33 & 115 & \\
\hline Total Percent & $75 \%$ & $25 \%$ & & $100 \%$ & $71 \%$ & $29 \%$ & & $100 \%$ \\
\hline
\end{tabular}

Table 2-2: Percent County in Forest Cover

\begin{tabular}{|c|c|c|c|c|c|c|}
\hline \multirow{2}{*}{$\begin{array}{l}\text { Ownership } \\
\text { (Acres) }=\mathrm{e}_{\mathrm{i}}\end{array}$} & \multirow{2}{*}{$\begin{array}{c}\text { Heavy: } 80+\% \\
\text { Expected } \mathrm{e}_{\mathrm{i}}\end{array}$} & \multirow{2}{*}{$\frac{\text { Moderate: } 60-79 \%}{\text { Expected } \mathrm{e}_{\mathrm{i}}}$} & \multirow{2}{*}{$\begin{array}{c}\text { Total } \\
\text { Expected } \mathrm{e}_{\mathrm{i}}\end{array}$} & & & \\
\hline & & & & $\left(o_{i}-e_{i}\right)$ & $\left(o_{i}-e_{i}\right)^{2}$ & $\left(o_{i}-e_{i}\right)^{2} / e_{i}$ \\
\hline 10 to 99 & 73 & 25 & 98 & -7 & 49 & 0.5 \\
\hline 100 to 199 & 9 & 3 & 12 & 5 & 25 & 2.0833 \\
\hline 200 to 299 & 4 & 1 & 5 & 2 & 4 & 0.8 \\
\hline Totals 3 & 86 & 29 & 115 & & Statisti & 3.3833 \\
\hline
\end{tabular}

$\mathrm{K}=3$ categories

Degrees of Freedom $=2$

Reject $\mathrm{H}_{0}$ : if $\mathrm{CHI}^{2}>9.210 @$ Alpha 0.01 and 2 Degrees of Freedom

$3.3833<9.210$

Do not Reject $\mathrm{H}_{0}$ : because there is no significant difference between the observed and expected number of landowners responding in the three acreage and two cover types sampled for the Southern region of WV. 


\section{Appendix D-3}

Table 3-1: Breakdown of 451 Responses, by First Property Owned and Percent Forest Cover Region 3: Northwestern. $n=161$

\begin{tabular}{|c|c|c|c|c|c|c|c|c|}
\hline \multirow{3}{*}{$\begin{array}{l}\text { Ownership } \\
\text { (Acres) }=A_{i}\end{array}$} & \multicolumn{3}{|c|}{ Total Number of Owners Sampled } & & \multicolumn{2}{|c|}{ Number of Returns } & \multirow{3}{*}{ Number } & \multirow{3}{*}{$\begin{array}{l}\text { Percent } \\
\text { Returned }\end{array}$} \\
\hline & \multicolumn{2}{|c|}{ Percent County in Forest Cover } & \multirow{2}{*}{$\begin{array}{c}\text { Total Number } \\
\text { Sampled }\end{array}$} & \multirow{2}{*}{$\begin{array}{l}\text { Percent } \\
\text { Sampled }\end{array}$} & \multicolumn{2}{|c|}{ Percent County in Forest Cover } & & \\
\hline & Heavy: $80+\%$ & Moderate: $60-79 \%$ & & & Heavy: $80+\%$ & Moderate: $60-79 \%$ & & \\
\hline \multirow[b]{2}{*}{10 to 99} & \multirow[b]{2}{*}{201} & \multirow[b]{2}{*}{178} & \multirow[b]{2}{*}{379} & \multirow[b]{2}{*}{$85 \%$} & Observed: $\mathrm{O}_{\mathrm{i}}$ & Observed: $\mathrm{O}_{\mathrm{i}}$ & Observed: $\mathrm{O}_{\mathrm{i}}$ & \multirow[b]{2}{*}{$84 \%$} \\
\hline & & & & & 70 & 65 & 135 & \\
\hline \multirow[t]{2}{*}{100 to 199} & 26 & 23 & \multirow[t]{2}{*}{49} & \multirow{3}{*}{$\begin{array}{l}11 \% \\
4 \%\end{array}$} & 11 & 10 & 21 & \multirow{3}{*}{$\begin{array}{l}13 \% \\
3 \%\end{array}$} \\
\hline & 9 & 9 & & & 3 & 2 & 5 & \\
\hline Totals 3 & 236 & 210 & 446 & & 84 & 77 & 161 & \\
\hline Total Percent & $53 \%$ & $47 \%$ & & $100 \%$ & $52 \%$ & $48 \%$ & & $100 \%$ \\
\hline
\end{tabular}

Table 3-2: Percent County in Forest Cover

\begin{tabular}{|c|c|c|c|c|c|c|}
\hline \multirow{2}{*}{$\begin{array}{l}\text { Ownership } \\
\text { (Acres) }=e_{i}\end{array}$} & \multirow{2}{*}{$\begin{array}{r}\text { Heavy: } 80+\% \\
\text { Expected } \mathrm{e}_{\mathrm{i}}\end{array}$} & \multirow{2}{*}{$\frac{\text { Moderate: } 60-79 \%}{\text { Expected } \mathrm{e}_{\mathrm{i}}}$} & \multirow{2}{*}{$\begin{array}{c}\text { Total } \\
\text { Expected } \mathrm{e}_{\mathrm{i}}\end{array}$} & \multirow[b]{2}{*}{$\left(o_{i}-e_{i}\right)$} & \multirow[b]{2}{*}{$\left(o_{i}-e_{i}\right)^{2}$} & \multirow[b]{2}{*}{$\left(o_{i}-e_{i}\right)^{2} / e$} \\
\hline & & & & & & \\
\hline 10 to 99 & 73 & 64 & 137 & -2 & 4 & 0.0292 \\
\hline 100 to 199 & 10 & 8 & 18 & 3 & 9 & 0.5 \\
\hline 200 to 299 & 3 & 3 & 6 & -1 & 1 & 0.2 \\
\hline Totals 3 & 86 & 75 & 161 & & 2 Statisti & 0.7292 \\
\hline
\end{tabular}

$\mathrm{K}=3$ categories

Degrees of Freedom $=2$

Reject $\mathrm{H}_{0}$ : if $\mathrm{CHI}^{2}>9.210 @$ Alpha 0.01 and 2 Degrees of Freedom

$0.7292<9.210$

Do not Reject $\mathrm{H}_{0}$ : because there is no significant difference between the observed and expected number of landowners responding in the three acreage and two cover types sampled for the Northwestern region of WV. 


\section{Appendix E-1}

\section{Forest Health Assistance}

(i.) Demographics:

Three demographic characteristics were significant for the 252 landowners requesting forest health assistance. Respondents age $26-49$ years old (Chi2 $=13.58,2 \mathrm{df})$, owning forest property from $1-10$ years $($ Chi2 $=4.55,2 \mathrm{df})$ and earning $>\$ 30,000$ per year $($ Chi2 $=12.01,4 \mathrm{df})$ were more likely to be interested in forest health issues (Table 1-1). The ANOVA indicated that landowners wanting forest health assistance tend to have on average significantly larger properties, higher incomes and educational levels than those not wanting forest health assistance. They also tend to average less years of forest ownership than those not interested in forest health issues (Table 1-1).

(ii.) Property Uses:

The five most importantly ranked of the fifteen significant property uses for landowners wanting forest health assistance were investment (Chi2 $=31.96,5 \mathrm{df})$, wildlife habitat $($ Chi2 $=36.26,5 \mathrm{df})$, visual beauty $($ Chi2 $=37.40,5 \mathrm{df})$, timber production $($ Chi2 $=46.62,5 \mathrm{df})$ and livestock pasturage $($ Chi2 $=35.82,5 \mathrm{df})($ Table $1-1)$. These same property uses were indicated in the ANOVA as being on average more important for landowners interested in forest health issues than those not interested in this assistance topic (Table 1-1).

(iii) Activities:

Twelve activities conducted within property owned by NIPF respondents wanting forest health assistance were significant. Forest health activities (Chi2 $=19.15,1 \mathrm{df})$, grapevine control $($ Chi2 $=11.22,1 \mathrm{df})$, building trails $($ Chi2 $=10.74,1 \mathrm{df})$ and improving visual beauty $($ Chi2 $=9.58$, 1df) were the most likely practices conducted within the property of landowners interested in forest health issues Table 1-1). The ANOVA identified that respondents wanting forest health assistance were more likely on average to have conducted these same activities within their forest properties than landowners not wanting this topic (Table 1-1).

(iv.) Assisting Agencies: 
Landowners requesting forest health assistance were more likely to have received assistance in the past from the WV State Division of Forestry (Chi2 $=24.30,1 \mathrm{df})$ and the WVU Extension Service $(\mathrm{Chi} 2=10.30,1 \mathrm{df})$. The ANOVA test of means revealed that on average landowners wanting this topic were more likely to have used these three agencies than those not interested in forest health issues (Table 1-1).

(v.) Logistic Regression Model (6df): Forest Health Assistance:

The model indicated that landowners interested in forest health issues tend to have higher income levels $(p=0.05)$ as well as use their property for wildlife habitat $(p=0.00)$ and timber production $(p=0.00)$ (Table). They were also more inclined to conduct, within their forested ownership's, forest health activities $(p=0.00)$ and property leases $(p=0.07)$ while receiving help from the WV State Division of Forestry $(p=0.00)$. The positive relationships between these characteristics suggest that this group of landowners realize that damaging agents can jeopardize habitat for wildlife and timber while also negatively influencing the leasing of their forest property, but they need more assistance.

The model produced odds of $4.8: 1$ that these variables correctly predict respondents wanting and not wanting forest health assistance $\left(\mathrm{Chi}^{2}=85.8,6 \mathrm{df}, \mathrm{p}=0.00\right)$ while correctly predicting $78 \%$ and $58 \%$ of those requesting and not requesting this assistance topic. The change in the $\mathrm{Chi}^{2}$-value between the first (39df) and second (6df) models was not significant proving the second model parsimonious for identifying the significant characteristics of the landowners wanting forest health assistance (Table 1-2). 


\section{Appendix E-2}

Table 1-1: Pearson's $\mathrm{Chi}^{2}$ and Analysis of Variance Values of Significance

Dependent and Grouping Variable: Forest Health Assistance: p-Value Significant @ $\leq \mathbf{0 . 1 0}$

\begin{tabular}{|c|c|c|c|c|c|c|}
\hline $\begin{array}{l}p-\text { Value Significant } \leq 0.01^{* * *} \\
p-\text { Value Significant } \leq 0.05^{* *} \\
p-\text { Value Significant } \leq 0.10^{*}\end{array}$ & \multicolumn{2}{|c|}{$\begin{array}{l}\text { Pearson's } \\
\mathrm{CHI}^{2} \text { Analysis }\end{array}$} & Analysis of & $\begin{array}{l}\text { Variance }(\mathrm{A} \\
\text { Forest Healt } \\
\text { Test of Mea }\end{array}$ & $\begin{array}{l}\text { NOVA) } \\
\text { רssistance } \\
\text { is (ANOVA) }\end{array}$ & Requests \\
\hline INDEPENDENT VARIABLES & $\begin{array}{r}\mathrm{CHI}^{2} \text { Value } \\
\&\left(\mathrm{df}^{\circ}\right)\end{array}$ & $\begin{array}{c}\text { CHI }^{2} \\
\text { P-VALUE }\end{array}$ & $\begin{array}{l}\text { ANOVA } \\
\text { p-Value }\end{array}$ & $\begin{array}{c}\text { No }=0 \\
\text { Means (199) }\end{array}$ & $\begin{array}{c}\text { Yes }=1 \\
\text { Means (252) }\end{array}$ & $\begin{array}{l}\text { Difference +/- } \\
\text { Means (451) }\end{array}$ \\
\hline DEMOGRAPHICS & & & & & & \\
\hline PROPERTY LANDSIZE & $1.38(2)$ & 0.50 & ${ }^{\star} 0.08$ & 71.83 & 81.89 & +10.06 \\
\hline LANDOWNER TENURE & $4.55(2)$ & ${ }^{\star} 0.10$ & $\star \star \star 0.01$ & 23.32 & 19.61 & -3.71 \\
\hline LANDOWNER INCOME & $12.01(4)$ & ${ }^{\star *} 0.02$ & ${ }^{\star * \star} 0.00$ & 2.90 & 3.63 & +0.73 \\
\hline LANDOWNER AGE & $13.58(2)$ & $\star \star \star 0.00$ & 0.95 & 54.70 & 54.81 & +0.11 \\
\hline LANDOWNER EDUCATION & $12.97(9)$ & 0.16 & $* * 0.04$ & 4.05 & 4.56 & +0.51 \\
\hline PROPERTY USES & & & & & & \\
\hline LANDOWNERS PLACE OF RESIDENCE & $16.78(5)$ & ${ }^{\star \star \star \star} 0.00$ & 0.22 & 3.67 & 3.89 & +0.22 \\
\hline PROPERTY AS AN INVESTMENT & $31.96(5)$ & $\star \star \star 0.00$ & $\star * \star 0.00$ & 2.12 & 2.99 & +0.87 \\
\hline WILDLIFE HABITAT & $36.26(5)$ & $\star \star \star 0.00$ & $\star \star \star 0.00$ & 2.61 & 3.55 & +0.94 \\
\hline HUNTING OR FISHING & $24.38(5)$ & ${ }^{\star \star *} 0.00$ & ${ }^{\star \star \star} 0.00$ & 2.35 & 2.87 & +0.52 \\
\hline WATESHED PROTECTION & $34.68(5)$ & $\star \star \star 0.00$ & $\star \star \star 0.00$ & 1.74 & 2.52 & +0.78 \\
\hline VISUAL BEAUTY & $37.40(5)$ & $* \star * 0.00$ & $\star \star \star * 0.00$ & 2.54 & 3.55 & +1.01 \\
\hline HIKING OR BIKING & $34.18(5)$ & $\star \star \star 0.00$ & $\star \star \star 0.00$ & 1.46 & 2.17 & +0.71 \\
\hline TIMBER PRODUCTION & $46.62(5)$ & $\star * \star 0.00$ & $* * * 0.00$ & 2.20 & 3.06 & +0.86 \\
\hline CHRISTMAS TREE FARM & $28.45(5)$ & $\star \star \star 0.00$ & $\star \star \star 0.00$ & 0.72 & 1.12 & +0.40 \\
\hline FRUIT TREE ORCHARD & $29.88(5)$ & $* * * 0.00$ & $\star \star \star 0.00$ & 0.92 & 1.46 & +0.54 \\
\hline GINSENG OR MUSHROOM PRODUCTION & $26.91(5)$ & $\star \star \star * 0.00$ & $\star \star \star * 0.00$ & 0.84 & 1.31 & +0.47 \\
\hline LIVESTOCK PASTURE & $35.82(5)$ & $\star * \star 0.00$ & ${ }^{\star *} 0.05$ & 1.99 & 2.34 & +0.35 \\
\hline FIREWOOD OR FENCE POSTS & $16.36(5)$ & $\star \star \star * 0.01$ & $\star \star \star * 01$ & 1.82 & 2.23 & +0.41 \\
\hline MAPLE SYRUP PRODUCTION & $23.57(5)$ & $\star * \star 0.00$ & $\star \star \star 0.00$ & 0.69 & 1.02 & +0.33 \\
\hline OTHER USES & $20.80(5)$ & $\star * \star 0.00$ & $\star \star \star 0.00$ & 0.98 & 1.45 & +0.47 \\
\hline FOREST ACTIVITY & & & & & & \\
\hline TIMBER HARVESTING & $1.82(1)$ & 0.18 & 0.18 & 0.40 & 0.46 & +0.06 \\
\hline PLANTED TREES & $8.26(1)$ & $\star \star \star * 0.00$ & $\star \star \star 0.00$ & 0.21 & 0.33 & +0.12 \\
\hline THINNED TREES & $7.36(1)$ & $* * * 0.00$ & $* * * 0.01$ & 0.31 & 0.44 & +0.13 \\
\hline CUT GRAPEVINES OR OTHER PLANTS & $11.22(1)$ & $\star \star \star * 0.00$ & $\star \star \star 0.00$ & 0.36 & 0.52 & +0.16 \\
\hline IMPROVE VISUAL BEAUTY & $9.58(1)$ & $* * * 0.00$ & $\star \star \star 0.00$ & 0.40 & 0.54 & +0.14 \\
\hline CONSTRUCTED TRAILS & $10.74(1)$ & $\star * \star 0.00$ & $\star * \star 0.00$ & 0.29 & 0.44 & +0.15 \\
\hline CONSTRUCTED ROADS & $4.23(1)$ & ${ }^{\star *} 0.04$ & ${ }^{\star *} 0.04$ & 0.44 & 0.54 & +0.10 \\
\hline PLANTED WILDLIFE FOOD CROPS & $6.49(1)$ & 0.11 & $\star \star \star 0.01$ & 0.19 & 0.29 & +0.10 \\
\hline IMPROVED SOIL RESOURCES & $9.09(1)$ & $* * * 0.00$ & $\star \star \star 0.00$ & 0.32 & 0.46 & +0.14 \\
\hline IMPROVED WATER RESOURCES & $5.79(1)$ & ${ }^{\star \star *} 0.02$ & ${ }^{\star \star} 0.02$ & 0.32 & 0.43 & +0.11 \\
\hline NON-TIMBER PRODUCTS (GINSENG etc.) & $4.25(1)$ & ${ }^{\star \star} 0.04$ & ${ }^{\star \star} 0.04$ & 0.08 & 0.14 & +0.06 \\
\hline PROPERTY BOUNDARY SURVEYED & $5.04(1)$ & ${ }^{\star \star} 0.02$ & ${ }^{\star \star} 0.02$ & 0.29 & 0.39 & +0.10 \\
\hline CONTROLLED DAMAGING AGENTS & $19.15(1)$ & $\star \star \star 0.00$ & $\star \star \star 0.00$ & 0.11 & 0.28 & +0.17 \\
\hline LEASED PROPERTY (TIMBER OR REC.) & $6.41(1)$ & $* * * 0.01$ & $\star \star \star 0.01$ & 0.01 & 0.04 & +0.03 \\
\hline OTHER FOREST ACTIVITIES & $1.82(1)$ & 0.18 & 0.18 & 0.09 & 0.13 & +0.04 \\
\hline ASSISTING AGENCIES & & & & & & \\
\hline WVU DIVISION OF FORESTRY & $2.14(1)$ & 0.14 & 0.14 & 0.15 & 0.20 & +0.05 \\
\hline WVU EXTENSION SERVICE & $10.30(1)$ & ${ }^{\star \star \star *} 0.00$ & ${ }^{\star \star \star *} 0.00$ & 0.10 & 0.21 & +0.11 \\
\hline
\end{tabular}




\section{Appendix E-3}

Table 1-2: Logistic Model (6df) Forest Health Assistance

\begin{tabular}{|c|c|c|c|c|c|c|c|c|}
\hline \multicolumn{6}{|c|}{$\begin{array}{l}\text { Model: Logistic regression (logit) N of 0's:199 1's:252 } \\
\text { Dep. var: HELTASST Loss: Max likelihood (MS-err. scaled to 1) } \\
\text { Final loss: } 266.59128751 \mathrm{Chi}^{2}(6)=85.793 \mathrm{p}=.00000\end{array}$} & \multicolumn{3}{|c|}{\begin{tabular}{|l}
$2^{*} \log ($ Likelihood) 533.1826 \\
Intercept Only: 618.9760
\end{tabular}} \\
\hline \multicolumn{4}{|l|}{ HELTASST } & \multirow{3}{*}{$\begin{array}{l}\text { HELTASST } \\
\begin{array}{c}\text { p-level } \\
\mathbf{0 . 0 0}\end{array}\end{array}$} & \multirow{2}{*}{\multicolumn{4}{|c|}{$\begin{array}{l}\text { Classification of Cases (owner.sta) } \\
\text { Odds ratio: } 4.9037\end{array}$}} \\
\hline & Estimate & Std.Err. & $\mathrm{t}(444)$ & & & & & \\
\hline Const.BO & -1.83 & 0.31 & -5.87 & & & Pred. & Pred. & Percent \\
\hline INCOME & 0.12 & 0.06 & 1.99 & 0.05 & OBSERVED & 0 & 1 & Correct \\
\hline WILDLIF2 & 0.23 & 0.06 & 3.89 & 0.00 & 0 & 115 & 84 & 57.78894 \\
\hline TIMBERP2 & 0.18 & 0.06 & 2.98 & 0.00 & 1 & 55 & 197 & 78.17461 \\
\hline FORHELTH & 0.93 & 0.28 & 3.29 & 0.00 & & & & \\
\hline LEASES & 1.98 & 1.07 & 1.85 & 0.07 & & & & \\
\hline WVFOREST & 0.69 & 0.23 & 3.04 & 0.00 & & & & \\
\hline
\end{tabular}

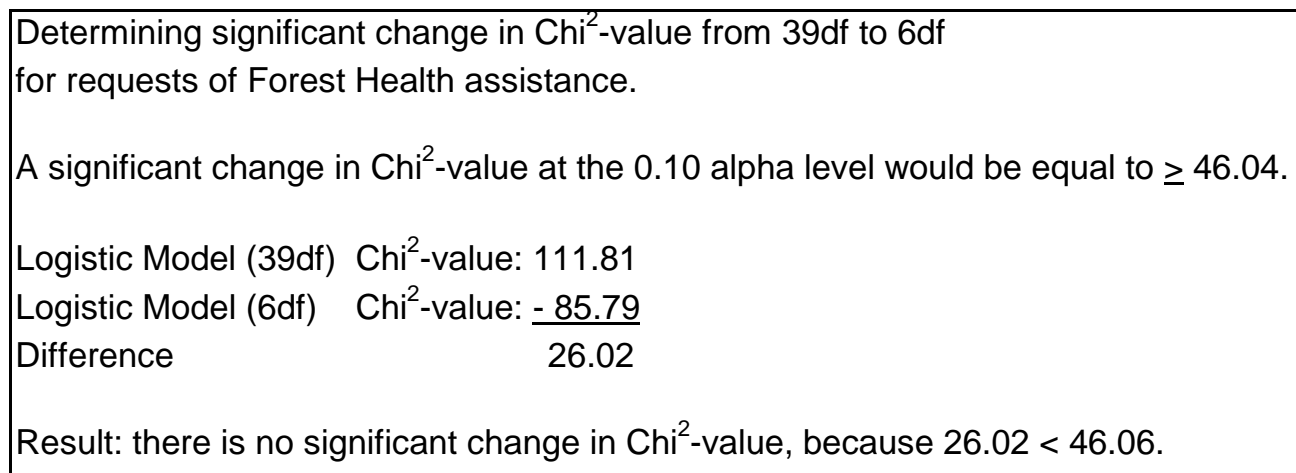




\section{Appendix F-1}

\section{Water Resource Assistance}

(i.) Demographics:

For the 245 respondents interested in water resource issues three demographic characteristics were significant. Landowners owning forest property from 1-10 years

$\left(\mathrm{Chi}^{2}=7.66,2 \mathrm{df}\right)$, earning $>\$ 30,000$ per year $\left(\mathrm{Chi}^{2}=18.12,2 \mathrm{df}\right)$ and age $26-49$ years old $\left(\mathrm{Chi}^{2}=18.68,2 \mathrm{df}\right)$ were the most likely to request water resource assistance (Table 2-1). The ANOVA indicated that landowners requesting this topic on average have significantly higher income and education levels than those not requesting water resource assistance do. They also tend to average less years of forest ownership than landowners not interested in water resource issues (Table 2-1).

(ii.) Property Uses:

The three most importantly ranked of the fifteen significant property uses, for landowners interested in water resource issues, were wildlife habitat $($ Chi2 $=30.79,5 \mathrm{df})$, visual beauty (Chi2 $=31.44,5 \mathrm{df})$, hunting or fishing $($ Chi2 $=26.12,5 \mathrm{df})$ and timber production $($ Chi2 $=26.81$, $5 \mathrm{df})$. These same uses of property in the ANOVA tend to be on average more important for those wanting water resource assistance than those not interested in this topic (Table 2-1).

(iii.) Activities:

Thirteen activities conducted within property owned by respondents wanting water resource assistance were significant. Landowners interested in water issues tend to have improved water $($ Chi2 $=16.70,1 \mathrm{df})$ and soil resources $($ Chi2 $=13.94,1 \mathrm{df})$, conducted tree thinnings (Chi2 $=13.05,1 \mathrm{df})$, built access roads $(\mathrm{Chi} 2=9.51,1 \mathrm{df})$ and improved visual beauty $($ Chi2 $=9.94,1 \mathrm{df})$ within their property $($ Table $2-1)$. The same practices were indicated in the ANOVA as being on average more commonly conducted by landowners requesting water resource assistance than those not requesting this topic (Table 2-1).

(iv.) Assisting Agencies:

Landowners wanting water resource assistance tend to have previously received help 
from the WV State Division of Forestry (Chi2 $=25.32,1 \mathrm{df}$ ) as well as the WVU Extension Service $($ Chi2 $=7.33,1 \mathrm{df})$ and Division of Forestry $(\mathrm{Chi} 2=6.29,1 \mathrm{df})$. The ANOVA revealed that on average respondents wanting this topic were likely to use these same agencies than landowners not requesting water resource assistance (Table 2-1).

(v.) Logistic Regression Model (4df): Water Resource Assistance:

The model (4df) indicates that landowners with a higher income level $(p=0.01)$ and using their property for livestock pasture $(p=0.02)$ tend to be more interested in water resource issues. Landowners wanting water resource assistance were also more likely to have conducted water improvement practices $(p=0.01)$ within their property and tend to have received help in the past from the WV State Division of Forestry $(p=0.00)$. The positive relationships between these characteristics indicates that this group of landowners is aware of the management required to sustain their water resources to support their reasons of ownership, but they are in need of further assistance.

This logistic model $($ Chi2 $=52.669,4 d f, p=0.00)$ correctly predicted $70 \%$ and $59 \%$ of the landowners wanting and not wanting this assistance topic. The model also produced odds of 3.3:1 that the variables used will correctly predict landowners that would or would not request water resource assistance. Even though the reduction in the $\mathrm{Chi}^{2}$-value between the first (39df) and second model (4df) was significant, the difference was only 1.2, indicating the second model to be parsimonious for identifying landowners interested in water resource issues (Table 2-2). 


\section{Appendix F-2}

Table 2-1: Pearson's $\mathrm{Chi}^{2}$ and Analysis of Variance Values of Significance

Dependent and Grouping Variable: Water Resources: p-Value Significant @ $\leq \mathbf{0 . 1 0}$

\begin{tabular}{|c|c|c|c|c|c|c|}
\hline $\begin{array}{l}p \text {-Value Significant } \leq 0.01^{* * *} \\
p \text {-Value Significant } \leq 0.05^{* *} \\
p-\text { Value Significant } \leq 0.10^{*}\end{array}$ & \multicolumn{2}{|c|}{$\begin{array}{l}\text { Pearson's } \\
\mathrm{CHI}^{2} \text { Analysis }\end{array}$} & \multicolumn{4}{|c|}{\begin{tabular}{|l} 
Analysis of Variance (ANOVA) \\
$\qquad \begin{array}{l}\text { Water Resource Assistance Requests } \\
\text { Test of Means (ANOVA) }\end{array}$
\end{tabular}} \\
\hline INDEPENDENT VARIABLES & $\begin{array}{r}\mathrm{CHI}^{2} \text { Value } \\
\&\left(\mathrm{df}^{\circ}\right)\end{array}$ & $\begin{array}{c}\text { CHI }^{2} \\
\text { P-VALUE }\end{array}$ & \begin{tabular}{|l|} 
ANOVA \\
$\mathrm{p}$-Value
\end{tabular} & $\begin{array}{c}\text { No }=0 \\
\text { Means (206) }\end{array}$ & $\begin{array}{c}\text { Yes }=1 \\
\text { Means (245) }\end{array}$ & $\begin{array}{c}\text { Difference +/- } \\
\text { Means (451) }\end{array}$ \\
\hline DEMOGRAPHICS & & & & & & \\
\hline PROPERTY LANDSIZE & $0.77(2)$ & 0.68 & 0.66 & 76.06 & 78.63 & +2.57 \\
\hline LANDOWNER TENURE & $7.66(2)$ & ${ }^{\star \star} 0.02$ & $\star \star \star 0.00$ & 24.09 & 18.85 & -5.24 \\
\hline LANDOWNER INCOME & $18.12(4)$ & ${ }^{\star \star *} 0.00$ & ${ }^{\star * \star} 0.00$ & 2.97 & 3.60 & +0.63 \\
\hline LANDOWNER AGE & $18.68(2)$ & $\star \star \star 0.00$ & 0.99 & 54.75 & 54.77 & +0.02 \\
\hline LANDOWNER EDUCATION & $10.54(9)$ & 0.31 & $\star \star \star 0.00$ & 3.95 & 4.66 & +0.71 \\
\hline PROPERTY USES & & & & & & \\
\hline LANDOWNERS PLACE OF RESIDENCE & $10.18(5)$ & ${ }^{*} 0.07$ & ${ }^{\star} 0.09$ & 3.63 & 3.93 & +0.30 \\
\hline PROPERTY AS AN INVESTMENT & $31.20(5)$ & $* * * 0.00$ & $\star \star \star 0.00$ & 2.20 & 2.94 & +0.74 \\
\hline WILDLIFE HABITAT & $30.79(5)$ & $\star \star \star 0.00$ & $\star \star \star 0.00$ & 2.68 & 3.51 & +0.83 \\
\hline HUNTING OR FISHING & $26.12(5)$ & ${ }^{\star \star *} 0.00$ & ${ }^{\star \star \star} 0.00$ & 2.27 & 2.95 & +0.68 \\
\hline WATESHED PROTECTION & $20.45(5)$ & $\star \star \star 0.00$ & $\star \star \star 0.00$ & 1.83 & 2.47 & +0.64 \\
\hline VISUAL BEAUTY & $31.44(5)$ & $* \star * 0.00$ & $\star \star \star * 0.00$ & 2.67 & 3.47 & +0.80 \\
\hline HIKING OR BIKING & $22.39(5)$ & $\star \star \star 0.00$ & $\star \star \star 0.01$ & 1.62 & 2.05 & +0.43 \\
\hline TIMBER PRODUCTION & $26.81(5)$ & $\star * \star 0.00$ & $* * * 0.00$ & 2.36 & 2.94 & +0.58 \\
\hline CHRISTMAS TREE FARM & $22.74(5)$ & $\star \star \star 0.00$ & $\star \star \star 0.00$ & 0.74 & 1.12 & +0.38 \\
\hline FRUIT TREE ORCHARD & $30.17(5)$ & $* * * 0.00$ & $\star \star \star 0.00$ & 0.93 & 1.48 & +0.55 \\
\hline GINSENG OR MUSHROOM PRODUCTION & $26.06(5)$ & $\star \star \star * 0.00$ & $\star \star \star * 0.00$ & 0.84 & 1.32 & +0.48 \\
\hline LIVESTOCK PASTURE & $40.50(5)$ & $* \star * 0.00$ & $\star \star \star 0.01$ & 1.94 & 2.40 & +0.46 \\
\hline FIREWOOD OR FENCE POSTS & $10.47(5)$ & ${ }^{*} 0.06$ & 0.20 & 1.94 & 2.14 & +0.20 \\
\hline MAPLE SYRUP PRODUCTION & $21.52(5)$ & $\star * \star 0.00$ & $\star \star \star 0.00$ & 0.73 & 1.00 & +0.27 \\
\hline OTHER USES & $11.50(5)$ & ${ }^{\star *} 0.04$ & ${ }^{*} 0.09$ & 1.11 & 1.36 & +0.25 \\
\hline FOREST ACTIVITY & & & & & & \\
\hline TIMBER HARVESTING & 2.99 (1) & ${ }^{\star} 0.08$ & ${ }^{\star} 0.08$ & 0.39 & 0.47 & +0.08 \\
\hline PLANTED TREES & $10.74(1)$ & $\star \star \star * 0.00$ & $\star \star \star 0.00$ & 0.20 & 0.34 & +0.14 \\
\hline THINNED TREES & $13.05(1)$ & $* * * 0.00$ & $* * * 0.00$ & 0.29 & 0.46 & +0.17 \\
\hline CUT GRAPEVINES OR OTHER PLANTS & $6.80(1)$ & $\star \star \star * 0.01$ & $\star \star \star 0.01$ & 0.38 & 0.51 & +0.13 \\
\hline IMPROVE VISUAL BEAUTY & 9.94 (1) & $* * * 0.00$ & $\star \star \star 0.00$ & 0.40 & 0.55 & +0.15 \\
\hline CONSTRUCTED TRAILS & $8.95(1)$ & $\star * \star 0.00$ & $\star * \star 0.00$ & 0.30 & 0.43 & +0.13 \\
\hline CONSTRUCTED ROADS & $9.51(1)$ & $* * * 0.00$ & $\star * \star 0.00$ & 0.42 & 0.56 & +0.14 \\
\hline PLANTED WILDLIFE FOOD CROPS & $12.79(1)$ & $\star \star \star 0.00$ & $\star \star \star 0.00$ & 0.17 & 0.31 & +0.14 \\
\hline IMPROVED SOIL RESOURCES & $13.94(1)$ & $* * * 0.00$ & $\star \star \star 0.00$ & 0.30 & 0.47 & +0.17 \\
\hline IMPROVED WATER RESOURCES & $16.70(1)$ & ${ }^{\star * \star} 0.00$ & ***0.00 & 0.28 & 0.47 & +0.19 \\
\hline NON-TIMBER PRODUCTS (GINSENG etc.) & $8.33(1)$ & ${ }^{\star \star *} 0.00$ & ${ }^{\star * \star} 0.00$ & 0.07 & 0.16 & +0.09 \\
\hline PROPERTY BOUNDARY SURVEYED & $6.36(1)$ & $\star * * 0.01$ & $\star \star \star * 0.01$ & 0.29 & 0.40 & +0.11 \\
\hline CONTROLLED DAMAGING AGENTS & $4.48(1)$ & ${ }^{\star \star} 0.03$ & ${ }^{\star \star} 0.03$ & 0.16 & 0.24 & +0.08 \\
\hline LEASED PROPERTY (TIMBER OR REC.) & $2.12(1)$ & 0.15 & 0.15 & 0.01 & 0.04 & +0.03 \\
\hline OTHER FOREST ACTIVITIES & $0.97(1)$ & 0.33 & 0.33 & 0.10 & 0.13 & +0.03 \\
\hline ASSISTING AGENCIES & & & & & & \\
\hline WVU DIVISION OF FORESTRY & $6.29(1)$ & ${ }^{\star \star *} 0.01$ & ${ }^{\star \star *} 0.01$ & 0.13 & 0.22 & +0.09 \\
\hline WVU EXTENSION SERVICE & $7.33(1)$ & ${ }^{* * *} 0.01$ & $\star * \star 0.01$ & 0.11 & 0.20 & +0.09 \\
\hline
\end{tabular}




\section{Appendix F-3}

Table 2-2: Logistic Model (4df) Water Resource Assistance

\begin{tabular}{|c|c|c|c|c|c|c|c|c|}
\hline \multicolumn{6}{|c|}{$\begin{array}{l}\text { Model: Logistic regression (logit) N of 0's:206 1's:245 } \\
\text { Dep. var: WATRASST Loss: Max likelihood (MS-err. scaled to 1) } \\
\text { Final loss: } 284.58665963 \mathrm{Chi}^{2}(4)=52.669 \mathrm{p}=.00000\end{array}$} & \multicolumn{3}{|c|}{$\begin{array}{l}-2^{*} \log \text { (Likelihood) } 569.1733 \\
\text { Intercept Only: } 621.8420\end{array}$} \\
\hline \multicolumn{4}{|l|}{ WATRASST } & \multirow{3}{*}{$\begin{array}{l}\text { WATRASST } \\
\begin{array}{c}\text { p-level } \\
\mathbf{0 . 0 0}\end{array}\end{array}$} & \multirow{2}{*}{\multicolumn{4}{|c|}{$\begin{array}{l}\text { Classification of Cases (owner.sta) } \\
\text { Odds ratio: } 3.2895\end{array}$}} \\
\hline \multirow{6}{*}{$\begin{array}{l}\text { Const.B0 } \\
\text { INCOME } \\
\text { LIVSTOC2 } \\
\text { IMPVWATR } \\
\text { WVFOREST }\end{array}$} & \multirow{3}{*}{$\begin{array}{c}\text { Estimate } \\
-1.20 \\
0.15\end{array}$} & \multirow{3}{*}{$\begin{array}{l}\text { Std.Err. } \\
0.26 \\
0.06\end{array}$} & \multirow{2}{*}{$\begin{array}{l}(446) \\
-4.63\end{array}$} & & & & & \\
\hline & & & & & & Pred. & Pred. & Percent \\
\hline & & & 2.70 & 0.01 & OBSERVED & 0 & 1 & Correct \\
\hline & 0.13 & 0.06 & 2.36 & 0.02 & 0 & 121 & 85 & 58.73787 \\
\hline & 0.59 & 0.21 & 2.77 & 0.01 & 1 & 74 & 171 & 69.79592 \\
\hline & 0.97 & 0.22 & 4.48 & 0.00 & & & & \\
\hline
\end{tabular}

\footnotetext{
Determining significant change in $\mathrm{Chi}^{2}$-value from 39df to 4df

for requests of Water Resource assistance.

A significant change in $\mathrm{Chi}^{2}$-value at the 0.10 alpha level would be equal to $\geq 46.04$.

Logistic Model (39df) Chi $^{2}$-value: 99.93

Logistic Model (4df) Chi' ${ }^{2}$-value: $\underline{-52.67}$

Difference $\quad 47.26$

Result: there was a slight significant change in $\mathrm{Chi}^{2}$-value, because $47.26>46.06$.
} 


\section{Appendix G-1}

\section{$\underline{\text { Silviculture Assistance }}$}

(i.) Demographics:

Two demographic characteristics were significant for the 238 respondents interested in silviculture issues. Landowners age $26-49$ years $\left(\mathrm{Chi}^{2}=16.64,2 \mathrm{df}\right)$ and owning forest property for 1-10 years $\left(\mathrm{Chi}^{2}=14.33,2 \mathrm{df}\right)$ were more likely want silviculture assistance (Table $\left.3-1\right)$. The ANOVA indicated that landowners wanting silviculture assistance tend to have on average significantly larger properties as well as higher income and education levels than those not interested in this topic. They also on average were more likely to be recent forest owners than respondents not interested in silviculture issues (Table 3-1).

(ii.) Property Uses:

Visual beauty $\left(\mathrm{Chi}^{2}=50.26,5 \mathrm{df}\right)$, investment, $\left(\mathrm{Chi}^{2}=44.34,5 \mathrm{df}\right)$, timber production $\left(\mathrm{Chi}^{2}=43.15,5 \mathrm{df}\right)$ and wildlife habitat $\left(\mathrm{Chi}^{2}=37.47,5 \mathrm{df}\right)$ were the most importantly ranked of the fifteen significant property uses for landowners interested in silviculture issues (Table 3-1). The ANOVA revealed that on average these same property uses were more important for landowners wanting silviculture assistance than those not interested in this topic (Table 3-1).

(iii.) Activities:

Thirteen forestry practices were significant for respondents wanting silviculture assistance. Landowners interested in silviculture issues tend to have conducted tree thinnings $\left(C_{i}{ }^{2}=15.44,1 \mathrm{df}\right)$, removed vines $\left(\mathrm{Chi}^{2}=14.20,1 \mathrm{df}\right)$, constructed trails $\left(\mathrm{Chi}^{2}=15.07, \mathrm{p}=0.00\right)$ and access roads $\left(\mathrm{Chi}^{2}=12.57,1 \mathrm{df}\right)$ as well as improved visual beauty $\left(\mathrm{Chi}^{2}=9.14, \mathrm{p}=0.00\right)$ within their forest property (Table 3-1). These same forestry practices were indicated in the ANOVA as being on average more likely to be conducted by landowners requesting silviculture assistance than those not requesting this topic (Table 3-1).

(iv.) Assisting Agencies:

The agencies most likely to have previously provided assistance to landowners interested 
in silviculture issues were the WV State Division of Forestry $\left(\mathrm{Chi}^{2}=39.82,1 \mathrm{df}\right)$ as well as the WVU Division of Forestry $\left(\mathrm{Chi}^{2}=4.25,1 \mathrm{df}\right)$ and Extension Service $\left(\mathrm{Chi}^{2}=8.92,1 \mathrm{df}\right)($ Table 3-1). In the ANOVA these three agencies were more likely on average to have previously helped respondents wanting silviculture assistance than those not interested in this topic (Table 3-1). (v.) Logistic Regression Model (7df): Silviculture Assistance:

The model (7df) indicated that NIPF owners interested in silviculture issues tend to be more recent owners $(p=0.01)$ while using their property for investment $(p=0.00)$, timber production $(p=0.06)$ and other uses $(p=0.03)$. Landowners wanting silviculture assistance were also more likely to grow or harvest non-timber products $(p=0.04)$ and conduct other activities $(p=0.01)$ such as building fences within their property. The WV State Division of Forestry $(p=0.00)$ was the agency most likely to have previously helped landowners interested in silviculture issues. The relationship between these characteristics suggests that this group of landowners recognize that their preferred property uses and forest activities require silviculture assistance, which can be economically and biologically complicated.

This model $\left(\mathrm{Chi}^{2}=89.801,7 \mathrm{df}, \mathrm{p}=0.00\right)$ correctly predicted $71 \%$ and $65 \%$ of the respondents wanting and not wanting silviculture assistance while producing odds of $4.6: 1$ that these variables can identify landowners interested and not interested in silviculture issues. The change in $\mathrm{Chi}^{2}$-value between the first (39df) and second (7df) models was not significant making the second model parsimonious for identifying respondents wanting silviculture assistance (Table 3-2). 


\section{Appendix G-2}

Table 3-1: Pearson's $\mathrm{Chi}^{2}$ and Analysis of Variance Values of Significance

Dependent and Grouping Variable: Silviculture: $p$-Value Significant $@ \leq \mathbf{0 . 1 0}$

\begin{tabular}{|c|c|c|c|c|c|c|}
\hline $\begin{array}{l}p-\text { Value Significant } \leq 0.01^{* * *} \\
p-\text { Value Significant } \leq 0.05^{* *} \\
p-\text { Value Significant } \leq 0.10^{*}\end{array}$ & \multicolumn{2}{|c|}{$\begin{array}{l}\text { Pearson's } \\
\mathrm{CH}^{2} \text { Analysis }\end{array}$} & Analysis of & $\begin{array}{l}\text { Variance }(\mathrm{Al} \\
\text { Silviculture } A \\
\text { Test of Mear }\end{array}$ & $\begin{array}{l}\text { IOVA) } \\
\text { ssistance Re } \\
\text { s (ANOVA) }\end{array}$ & quests \\
\hline INDEPENDENT VARIABLES & $\begin{array}{r}\mathrm{CHI}^{2} \text { Value } \\
\quad \&\left(\mathrm{df}^{\circ}\right)\end{array}$ & $\begin{array}{c}\text { CHI }^{2} \\
\text { P-VALUE }\end{array}$ & $\begin{array}{l}\text { ANOVA } \\
\text { p-Value }\end{array}$ & \begin{tabular}{|c|} 
No $=0$ \\
Means (206)
\end{tabular} & $\begin{array}{c}\text { Yes }=1 \\
\text { Means (245) }\end{array}$ & $\begin{array}{l}\text { Difference +/- } \\
\text { Means (451) }\end{array}$ \\
\hline DEMOGRAPHICS & & & & & & \\
\hline PROPERTY LANDSIZE & $1.66(2)$ & 0.44 & ${ }^{*} 0.06$ & 71.84 & 82.48 & +10.64 \\
\hline LANDOWNER TENURE & $14.33(2)$ & $\star \star * 0.00$ & $\star \star \star 0.00$ & 24.04 & 18.74 & -5.30 \\
\hline LANDOWNER INCOME & $6.21(4)$ & 0.18 & ${ }^{* *} 0.05$ & 3.14 & 3.47 & +0.33 \\
\hline LANDOWNER AGE & $16.64(2)$ & $* * * 0.00$ & 0.58 & 55.27 & 54.30 & -0.97 \\
\hline LANDOWNER EDUCATION & $14.42(9)$ & 0.11 & *0.09 & 4.12 & 4.53 & +0.41 \\
\hline PROPERTY USES & & & & & & \\
\hline LANDOWNERS PLACE OF RESIDENCE & $10.48(5)$ & ${ }^{*} 0.06$ & ${ }^{\star} 0.09$ & 3.64 & 3.93 & +0.29 \\
\hline PROPERTY AS AN INVESTMENT & $44.34(5)$ & $* * * 0.00$ & $* * * 0.00$ & 2.12 & 3.04 & +0.92 \\
\hline WILDLIFE HABITAT & $37.47(5)$ & $\star \star \star * 0.00$ & $\star \star \star 0.00$ & 2.73 & 3.50 & +0.77 \\
\hline HUNTING OR FISHING & $30.27(5)$ & $\star \star * 0.00$ & ${ }^{* \star} 0.03$ & 2.44 & 2.82 & +0.38 \\
\hline WATESHED PROTECTION & $33.54(5)$ & $\star \star \star * 0.00$ & $\star \star \star 0.00$ & 1.77 & 2.54 & +0.77 \\
\hline VISUAL BEAUTY & $50.26(5)$ & ${ }^{\star * *} 0.00$ & ${ }^{\star * \star} 0.00$ & 2.52 & 3.62 & +1.10 \\
\hline HIKING OR BIKING & $31.65(5)$ & $\star \star \star * 0.00$ & $\star \star \star 0.00$ & 1.43 & 2.23 & +0.80 \\
\hline TIMBER PRODUCTION & $43.15(5)$ & $* * * 0.00$ & $\star \star \star 0.00$ & 2.21 & 3.10 & +0.89 \\
\hline CHRISTMAS TREE FARM & $20.75(5)$ & $\star \star * * 00$ & $\star \star \star 0.01$ & 0.80 & 1.08 & +0.28 \\
\hline FRUIT TREE ORCHARD & $23.61(5)$ & ${ }^{* * *} 0.00$ & ${ }^{* \star *} 0.00$ & 0.93 & 1.49 & +0.56 \\
\hline GINSENG OR MUSHROOM PRODUCTION & $18.74(5)$ & $\star \star * 0.00$ & $\star \star \star 0.00$ & 0.89 & 1.29 & +0.40 \\
\hline LIVESTOCK PASTURE & $21.06(5)$ & $* * * 0.00$ & 0.35 & 2.10 & 2.26 & +0.16 \\
\hline FIREWOOD OR FENCE POSTS & $21.06(5)$ & $\star * \star 0.00$ & $\star \star \star 0.00$ & 1.77 & 2.31 & +0.54 \\
\hline MAPLE SYRUP PRODUCTION & $16.12(5)$ & $\star \star \star * 0.01$ & $\star \star \star 0.00$ & 0.73 & 1.01 & +0.28 \\
\hline OTHER USES & $24.33(5)$ & ${ }^{* * *} 0.00$ & $\star * \star 0.00$ & 0.93 & 1.53 & +0.60 \\
\hline FOREST ACTIVITY & & & & & & \\
\hline TIMBER HARVESTING & $0.94(1)$ & 0.33 & 0.33 & 0.41 & 0.45 & +0.04 \\
\hline PLANTED TREES & $9.30(1)$ & $\star \star \star 0.00$ & $\star \star \star 0.00$ & 0.21 & 0.34 & +0.13 \\
\hline THINNED TREES & $15.44(1)$ & $\star \star \star 0.00$ & $\star \star \star 0.00$ & 0.29 & 0.47 & +0.18 \\
\hline CUT GRAPEVINES OR OTHER PLANTS & $14.20(1)$ & $\star * \star 0.00$ & $\star \star \star 0.00$ & 0.36 & 0.53 & +0.17 \\
\hline IMPROVE VISUAL BEAUTY & $9.14(1)$ & $\star \star \star 0.00$ & $\star \star \star 0.00$ & 0.40 & 0.55 & +0.15 \\
\hline CONSTRUCTED TRAILS & $15.07(1)$ & ${ }^{\star \star *} 0.00$ & ${ }^{\star * \star} 0.00$ & 0.28 & 0.45 & +0.17 \\
\hline CONSTRUCTED ROADS & $12.57(1)$ & $\star \star \star 0.00$ & $\star \star \star 0.00$ & 0.41 & 0.58 & +0.16 \\
\hline PLANTED WILDLIFE FOOD CROPS & $5.79(1)$ & ${ }^{* \star} 0.02$ & ${ }^{* *} 0.02$ & 0.19 & 0.29 & +0.10 \\
\hline IMPROVED SOIL RESOURCES & $3.06(1)$ & ${ }^{\star} 0.08$ & *0.08 & 0.35 & 0.43 & +0.08 \\
\hline IMPROVED WATER RESOURCES & $2.23(1)$ & 0.14 & 0.14 & 0.35 & 0.42 & +0.07 \\
\hline NON-TIMBER PRODUCTS (GINSENG etc.) & $7.97(1)$ & $\star \star \star * 0.00$ & $\star \star \star 0.00$ & 0.07 & 0.16 & +0.09 \\
\hline PROPERTY BOUNDARY SURVEYED & $1.48(1)$ & 0.22 & 0.22 & 0.32 & 0.37 & +0.05 \\
\hline CONTROLLED DAMAGING AGENTS & $5.98(1)$ & $\star * \star 0.01$ & $\star * \star 0.01$ & 0.15 & 0.25 & +0.10 \\
\hline LEASED PROPERTY (TIMBER OR REC.) & $0.96(1)$ & 0.33 & 0.33 & 0.02 & 0.03 & +0.01 \\
\hline OTHER FOREST ACTIVITIES & $10.90(1)$ & $\star \star \star 0.00$ & ${ }^{\star \star \star} 0.00$ & 0.06 & 0.16 & +0.10 \\
\hline ASSISTING AGENCIES & & & & & & \\
\hline
\end{tabular}


WVU DIVISION OF FORESTRY WVU EXTENSION SERVICE WV STATE DIVISION OF FORESTRY \begin{tabular}{r|r|r|}
$4.25(1)$ & ${ }^{\star \star} 0.04$ & ${ }^{\star \star} 0.04$ \\
$8.91(1)$ & ${ }^{* \star} 0.00$ & ${ }^{* \star \star} 0.00$ \\
$39.82(1)$ & ${ }^{\star \star *} 0.00$ & ${ }^{\star \star \star} 0.00$ \\
\hline
\end{tabular}
0.14
0.10
0.22

\section{Appendix G-3}

Table 3-2: Logistic Model (7df) Silviculture Assistance

\begin{tabular}{|c|c|c|c|c|c|c|c|c|}
\hline \multicolumn{5}{|c|}{$\begin{array}{l}\text { Model: Logistic regression (logit) N of 0's:213 1's:238 } \\
\text { Dep. var: SILVICUL Loss: Max likelihood (MS-err. scaled to } 1 \\
\text { Final loss: } 267.01580335 \mathrm{Chi}^{2}(7)=89.801 \mathrm{p}=.00000\end{array}$} & & \multicolumn{3}{|c|}{$\begin{array}{l}-2^{*} \log (\text { Likelihood) } 534.0316 \\
\text { Intercept Only: } 623.8322\end{array}$} \\
\hline \multicolumn{4}{|c|}{ SILVICULTURE } & \multirow{3}{*}{$\begin{array}{c}\text { SILVICUL } \\
\text { p-level } \\
\mathbf{0 . 0 2}\end{array}$} & \multirow{2}{*}{\multicolumn{4}{|c|}{$\begin{array}{l}\text { Classification of Cases (owner.sta) } \\
\text { Odds ratio: } 4.6007\end{array}$}} \\
\hline \multirow{3}{*}{$\begin{array}{l}\text { Const.B0 } \\
\text { TENRGRUP }\end{array}$} & \multirow{2}{*}{$\begin{array}{c}\text { Estimate } \\
-0.82\end{array}$} & \multirow{2}{*}{$\begin{array}{l}\text { Std.Err. } \\
\mathbf{0 . 3 4}\end{array}$} & \multirow{2}{*}{$\begin{array}{l}\mathrm{t}(443) \\
-2.40\end{array}$} & & & & & \\
\hline & & & & & & Pred. & Pred. & Percent \\
\hline & -0.28 & 0.11 & -2.45 & 0.01 & OBSERVED & 0 & 1 & Correct \\
\hline INVESTM2 & 0.19 & 0.06 & 3.05 & 0.00 & 0 & 139 & 74 & 65.25822 \\
\hline TIMBERP2 & 0.12 & 0.06 & 1.87 & 0.06 & 1 & 69 & 169 & 71.0084 \\
\hline OTHRUSE2 & 0.16 & 0.07 & 2.19 & 0.03 & & & & \\
\hline OTHFOPD & 0.74 & 0.35 & 2.11 & 0.04 & & & & \\
\hline OTHERACT & 0.91 & 0.37 & 2.49 & 0.01 & & & & \\
\hline WVFOREST & 0.92 & 0.23 & 4.09 & 0.00 & & & & \\
\hline
\end{tabular}

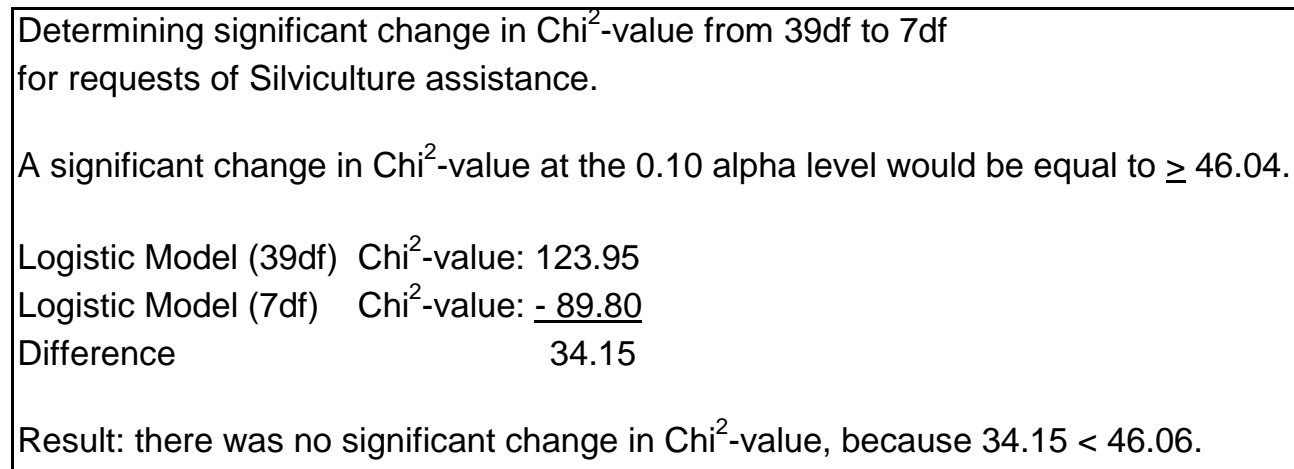




\section{Appendix $\mathrm{H}-1$}

\section{Wildlife Habitat Assistance}

(i.) Demographics:

Four demographic characteristics were significant for the 235 landowners interested in wildlife habitat assistance. Respondents owning property for $1-10$ years $\left(\mathrm{Chi}^{2}=33.40,2 \mathrm{df}\right)$ in the southern region of $\mathrm{WV}\left(\mathrm{Chi}^{2}=9.13,3 \mathrm{df}\right)$, age $26-49$ years old $\left(\mathrm{Chi}^{2}=24.75,2 \mathrm{df}\right)$ and earning $>\$ 30,000$ per year $\left(\mathrm{Chi}^{2}=14.84,4 \mathrm{df}\right)$ were more likely to request wildlife habitat assistance (Table 4-1). The ANOVA indicated that landowners requesting wildlife habitat assistance tend to be on average older in age and have higher incomes than those not interested in wildlife habitat issues. They were also more likely to average less years of forest ownership than respondents not requesting this topic of assistance (Table 4-1).

(ii.) Property Uses:

Wildlife habitat $\left(\mathrm{Chi}^{2}=56.61,5 \mathrm{df}\right)$, hunting or fishing $\left(\mathrm{Chi}^{2}=55.13,5 \mathrm{df}\right)$, visual beauty $\left(\mathrm{Chi}^{2}=27.19,5 \mathrm{df}\right)$, timber production $\left(\mathrm{Chi}^{2}=26.78,5 \mathrm{df}\right)$ and investment $\left(\mathrm{Chi}^{2}=20.76,5 \mathrm{df}\right)$ were the most importantly ranked of the fifteen significant property uses for landowners requesting wildlife habitat assistance (Table 4-1). The ANOVA indicated that these same property uses on average were more important for owners interested in wildlife habitat issues than those not interested in this topic (Table 4-1).

(iv.) Activities:

Thirteen forest activities conducted within property owned by respondents interested in wildlife habitat issues were significant. Landowners wanting wildlife habitat assistance were more likely to have built trails $\left(\mathrm{Chi}^{2}=27.74,1 \mathrm{df}\right)$ and access roads $\left(\mathrm{Chi}^{2}=20.96,1 \mathrm{df}\right)$ as well as improved visual beauty $\left(\mathrm{Chi}^{2}=14.89,1 \mathrm{df}\right)$, conducted tree thinnings $\left(\mathrm{Chi}^{2}=12.72,1 \mathrm{df}\right)$ and planted wildlife food crops $\left(\mathrm{Chi}^{2}=31.78,1 \mathrm{df}\right)($ Table $4-1)$. These same activities were indicated in the ANOVA as being on average more commonly conducted by landowners interested in wildlife habitat issues than those not interested (Table 4-1). 
(iv.) Assisting Agencies:

Landowners requesting wildlife habitat assistance tend to have previously received help from the WV State Division of Forestry $\left(\mathrm{Chi}^{2}=24.64,1 \mathrm{df}\right)$ as well as the WVU Division of Forestry $\left(\mathrm{Chi}^{2}=13.54,1 \mathrm{df}\right)$ and Extension Service $\left(\mathrm{Chi}^{2}=8.11,1 \mathrm{df}\right)$. The ANOVA indicated that landowners interested in wildlife habitat assistance were more likely on average to have received assistance in the past from these same agencies than those not wanting this topic (Table 4-1).

(v.) Logistic Regression Model (9df): Wildlife Habitat Assistance:

This model (9df) revealed that NIPF owners wanting wildlife habitat assistance tend to be recent owners $(p=0.00)$ and have higher incomes $(p=0.04)$. They tend to use their property for a place to live $(p=0.08)$, wildlife habitat $(p=0.00)$ and hunting or fishing $(p=0.00)$ while also being more likely to plant wildlife food crops $(p=0.00)$ within their property (Table). In addition, respondents more likely to be interested in wildlife habitat improvements were those previously receiving help from the WV State $(p=0.00)$ and University $(p=0.04)$ Divisions of Forestry. The negative relationship of watershed protection $(p=0.01)$ with requests for wildlife habitat assistance suggests that this group of landowners would like assistance to manage wildlife without disrupting watershed quality. Additionally, the positive relationship between these characteristics suggests that this group of landowners realize they need wildlife habitat improvement assistance given their preferred property uses and activities conducted.

This model $\left(\mathrm{Chi}^{2}=120.11,9 \mathrm{df}, \mathrm{p}=0.00\right)$ correctly predicted $72 \%$ and $70 \%$ of the respondents wanting and not wanting this assistance topic while producing odds of 5.9:1 that these variables can identify landowners wanting and not wanting wildlife habitat assistance. The change in $\mathrm{Chi}^{2}$-value between the first (39df) and second (9df) models was not significant making the second model parsimonious for identifying landowners wanting wildlife habitat improvement assistance. 
Appendix H-2

Table 4-1: Pearson's $\mathrm{Chi}^{2}$ and Analysis of Variance Values of Significance

Dependent and Grouping Variable: Wildlife Assistance: p-Value Significant @ $\leq \mathbf{0 . 1 0}$

\begin{tabular}{|c|c|c|c|c|c|c|}
\hline $\begin{array}{l}p-\text { Value Significant } \leq 0.01^{* * *} \\
p-\text { Value Significant } \leq 0.05^{* *} \\
p-\text { Value Significant } \leq 0.10^{*}\end{array}$ & \multicolumn{2}{|c|}{$\begin{array}{l}\text { Pearson's } \\
\mathrm{CHI}^{2} \text { Analysis }\end{array}$} & Analysis of & $\begin{array}{l}\text { Variance }(\mathrm{Al} \\
\begin{array}{l}\text { Wildlife Habi } \\
\text { Test of Mear }\end{array}\end{array}$ & $\begin{array}{l}\text { JOVA) } \\
\text { at Assistance } \\
\text { is (ANOVA) }\end{array}$ & Requests \\
\hline INDEPENDENT VARIABLES & $\begin{array}{r}\mathrm{CHI}^{2} \text { Value } \\
\quad \&\left(\mathrm{df}^{\circ}\right)\end{array}$ & $\begin{array}{c}\text { CHI }^{2} \\
\text { P-VALUE }\end{array}$ & $\begin{array}{l}\text { ANOVA } \\
\text { p-Value }\end{array}$ & \begin{tabular}{|c|} 
No $=0$ \\
Means (216)
\end{tabular} & $\begin{array}{c}\text { Yes }=1 \\
\text { Means (235) }\end{array}$ & $\begin{array}{l}\text { Difference +/- } \\
\text { Means (451) }\end{array}$ \\
\hline DEMOGRAPHICS & & & & & & \\
\hline PROPERTY LANDSIZE & $0.36(2)$ & 0.84 & 0.20 & 73.60 & 81.00 & +7.40 \\
\hline LANDOWNER TENURE & $33.40(2)$ & $\star \star * 0.00$ & $\star \star \star 0.00$ & 25.50 & 17.33 & -8.17 \\
\hline LANDOWNER INCOME & $14.84(4)$ & $* * * 0.01$ & $\star \star \star 0.00$ & 2.96 & 3.63 & +0.67 \\
\hline LANDOWNER AGE & $24.75(2)$ & $* * * 0.00$ & ${ }^{\star} 0.08$ & 56.36 & 53.29 & +3.07 \\
\hline LANDOWNER EDUCATION & $11.65(9)$ & 0.23 & 0.13 & 4.14 & 4.51 & +0.37 \\
\hline PROPERTY USES & & & & & & \\
\hline LANDOWNERS PLACE OF RESIDENCE & $16.89(5)$ & ${ }^{\star \star *} 0.00$ & 0.28 & 3.69 & 3.89 & +0.20 \\
\hline PROPERTY AS AN INVESTMENT & $20.76(5)$ & $* * * 0.00$ & $* * * 0.00$ & 2.30 & 2.89 & +0.59 \\
\hline WILDLIFE HABITAT & $56.61(5)$ & $\star \star \star * 0.00$ & $\star \star \star 0.00$ & 2.51 & 3.70 & +1.19 \\
\hline HUNTING OR FISHING & $55.13(5)$ & $\star \star * * 00$ & $\star \star \star 0.00$ & 2.06 & 3.17 & +1.11 \\
\hline WATESHED PROTECTION & $21.10(5)$ & $\star \star \star * 0.00$ & $\star \star \star 0.00$ & 1.92 & 2.41 & +0.49 \\
\hline VISUAL BEAUTY & $27.19(5)$ & ${ }^{\star * *} 0.00$ & ${ }^{\star * \star} 0.00$ & 2.65 & 3.51 & +0.86 \\
\hline HIKING OR BIKING & $37.25(5)$ & $\star \star \star * 0.00$ & $\star \star \star 0.00$ & 1.55 & 2.14 & +0.59 \\
\hline TIMBER PRODUCTION & $26.78(5)$ & $* \star * 0.00$ & $\star \star \star 0.00$ & 2.39 & 2.94 & +0.55 \\
\hline CHRISTMAS TREE FARM & $33.60(5)$ & $\star \star * * 00$ & $\star \star \star 0.00$ & 0.71 & 1.16 & +0.45 \\
\hline FRUIT TREE ORCHARD & $25.36(5)$ & ${ }^{* * *} 0.00$ & $\star \star \star * 0.00$ & 0.95 & 1.48 & +0.53 \\
\hline GINSENG OR MUSHROOM PRODUCTION & $20.08(5)$ & $\star \star * 0.00$ & $\star \star \star 0.00$ & 0.91 & 1.28 & +0.37 \\
\hline LIVESTOCK PASTURE & $42.46(5)$ & $* * * 0.00$ & 0.31 & 2.10 & 2.27 & +0.17 \\
\hline FIREWOOD OR FENCE POSTS & $14.63(5)$ & $\star * \star 0.01$ & 0.14 & 1.93 & 2.16 & +0.23 \\
\hline MAPLE SYRUP PRODUCTION & $22.49(5)$ & $\star \star \star * 0.00$ & $\star \star \star 0.00$ & 0.74 & 1.00 & +0.26 \\
\hline OTHER USES & $11.79(5)$ & ${ }^{\star \star} 0.04$ & $\star * \star 0.00$ & 1.03 & 1.44 & +0.41 \\
\hline FOREST ACTIVITY & & & & & & \\
\hline TIMBER HARVESTING & $4.70(1)$ & ${ }^{\star \star} 0.03$ & 0.33 & 0.38 & 0.48 & +0.10 \\
\hline PLANTED TREES & $10.39(1)$ & $\star \star \star * 0.00$ & $\star \star \star 0.00$ & 0.21 & 0.34 & +0.13 \\
\hline THINNED TREES & $12.72(1)$ & ${ }^{\star * \star} 0.00$ & ${ }^{\star \star *} 0.00$ & 0.30 & 0.46 & +0.16 \\
\hline CUT GRAPEVINES OR OTHER PLANTS & $6.28(1)$ & $* * * 0.01$ & $\star \star \star 0.00$ & 0.39 & 0.51 & +0.12 \\
\hline IMPROVE VISUAL BEAUTY & $14.89(1)$ & $\star \star \star 0.00$ & $\star \star \star 0.00$ & 0.38 & 0.57 & +0.19 \\
\hline CONSTRUCTED TRAILS & 27.74 (1) & ${ }^{\star \star *} 0.00$ & ${ }^{\star * \star} 0.00$ & 0.25 & 0.49 & +0.24 \\
\hline CONSTRUCTED ROADS & $20.96(1)$ & $\star \star \star 0.00$ & $\star \star \star 0.00$ & 0.38 & 0.60 & +0.22 \\
\hline PLANTED WILDLIFE FOOD CROPS & $31.78(1)$ & $* \star * 0.00$ & ${ }^{* *} 0.02$ & 0.13 & 0.35 & +0.22 \\
\hline IMPROVED SOIL RESOURCES & $5.58(1)$ & ${ }^{\star \star} 0.02$ & $\star 0.08$ & 0.34 & 0.45 & +0.11 \\
\hline IMPROVED WATER RESOURCES & $5.28(1)$ & ${ }^{\star *} 0.02$ & 0.14 & 0.33 & 0.43 & +0.10 \\
\hline NON-TIMBER PRODUCTS (GINSENG etc.) & $10.36(1)$ & $\star \star \star * 0.00$ & $\star \star \star 0.00$ & 0.06 & 0.16 & +0.10 \\
\hline PROPERTY BOUNDARY SURVEYED & $6.81(1)$ & $* * * 0.01$ & 0.22 & 0.29 & 0.40 & +0.11 \\
\hline CONTROLLED DAMAGING AGENTS & $6.70(1)$ & $\star \star \star * 0.01$ & $* * * 0.01$ & 0.15 & 0.25 & +0.10 \\
\hline LEASED PROPERTY (TIMBER OR REC.) & $2.59(1)$ & 0.11 & 0.33 & 0.01 & 0.04 & +0.03 \\
\hline OTHER FOREST ACTIVITIES & $1.74(1)$ & 0.19 & ${ }^{\star \star \star} 0.00$ & 0.09 & 0.13 & +0.04 \\
\hline ASSISTING AGENCIES & & & & & & \\
\hline
\end{tabular}


WVU DIVISION OF FORESTRY WVU EXTENSION SERVICE WV STATE DIVISION OF FORESTRY \begin{tabular}{r|r|r|}
$13.54(1)$ & ${ }^{* \star \star} 0.00$ & ${ }^{* \star \star} 0.00$ \\
$8.11(1)$ & ${ }^{* \star *} 0.00$ & ${ }^{* \star \star} 0.00$ \\
$24.64(1)$ & ${ }^{* \star \star} 0.00$ & ${ }^{* \star *} 0.00$ \\
\hline
\end{tabular}

$$
{ }^{\star * \star} 0.00
$$

0.11
0.11
0.25

\section{Appendix H-3}

Table 4-2: Logistic Model (9df) Wildlife Assistance

\begin{tabular}{|c|c|c|c|c|c|c|c|c|}
\hline \multicolumn{6}{|c|}{$\begin{array}{l}\text { Model: Logistic regression (logit) N of 0's:216 1's:235 } \\
\text { Dep. var: WILDLIFE Loss: Max likelihood (MS-err. scaled to 1) } \\
\text { Final loss: } 252.15429209 \mathrm{Chi}^{2}(9)=120.11 \mathrm{p}=.00000\end{array}$} & \multicolumn{3}{|c|}{$\begin{array}{l}-2 * \log \text { (Likelihood) } 504.3086 \\
\text { Intercept Only: } 624.4181\end{array}$} \\
\hline \multicolumn{4}{|l|}{ WILDLIFE } & \multirow{3}{*}{$\begin{array}{l}\text { WILDLIFE } \\
\begin{array}{c}\text { p-level } \\
\mathbf{0 . 0 0}\end{array}\end{array}$} & \multirow{2}{*}{\multicolumn{4}{|c|}{$\begin{array}{l}\text { Classification of Cases (owner.sta) } \\
\text { Odds ratio: } 5.9485\end{array}$}} \\
\hline \multirow{3}{*}{$\begin{array}{l}\text { Const.BO } \\
\text { TENRGRUP }\end{array}$} & \multirow{2}{*}{$\begin{array}{c}\text { Estimate } \\
-1.33\end{array}$} & \multirow{2}{*}{$\begin{array}{l}\text { Std.Err. } \\
0.46\end{array}$} & \multirow{2}{*}{$\begin{array}{l}t(441) \\
-2.87\end{array}$} & & & & & \\
\hline & & & & & & Pred. & Pred. & Percent \\
\hline & -0.47 & 0.12 & -3.86 & 0.00 & OBSERVED & 0 & 1 & Correct \\
\hline INCOME & 0.13 & 0.06 & 2.06 & 0.04 & 0 & 151 & 65 & 69.90741 \\
\hline PLACLIV2 & 0.11 & 0.06 & 1.75 & 0.08 & 1 & 66 & 169 & 71.91489 \\
\hline WILDLIF2 & 0.28 & 0.08 & 3.57 & 0.00 & & & & \\
\hline HUNTFIS2 & 0.19 & 0.07 & 2.84 & 0.00 & & & & \\
\hline WATESHD2 & -0.18 & 0.07 & -2.44 & 0.01 & & & & \\
\hline WILDFOOD & 0.83 & 0.27 & 3.03 & 0.00 & & & & \\
\hline WVUNIDOF & 0.63 & 0.31 & 2.03 & 0.04 & & & & \\
\hline WVFOREST & 0.70 & 0.24 & 2.92 & 0.00 & & & & \\
\hline
\end{tabular}

Determining significant change in $\mathrm{Chi}^{2}$-value from 39df to 9df

for requests of Wildlife Habitat assistance.

A significant change in $\mathrm{Chi}^{2}$-value at the 0.10 alpha level would be equal to $\geq 46.04$.

Logistic Model (39df) Chi $^{2}$-value: 145.70

Logistic Model (9df) Chi ${ }^{2}$-value: $\underline{-120.11}$

Difference

25.59

Result: there was no significant change in $\mathrm{Chi}^{2}$-value, because $25.59<46.06$. 


\section{Appendix I-1}

\section{Landowner Liability, Property Rights and Tax Assistance}

(i.) Demographics:

For the 232 landowners interested in liability, property rights and tax issues, three demographic characteristics were significant. Respondents owning forest property for 1-10 years $\left(\mathrm{Chi}^{2}=14.90,2 \mathrm{df}\right)$, with income levels $>\$ 30,000$ per year $\left(\mathrm{Chi}^{2}=23.00,4 \mathrm{df}\right)$ and age $50-64$ years $\left(\mathrm{Chi}^{2}=12.96,2 \mathrm{df}\right)$ were more likely to request this type of assistance (Table 5-1). The ANOVA indicated that respondents interested in these issues tend to average higher income and education levels than those not interested in this topic. They also tend to average less years of forest ownership than the respondents not wanting liability, property rights and tax assistance do (Table 5-1).

(ii.) Property Uses:

Investment $\left(\mathrm{Chi}^{2}=23.36,5 \mathrm{df}\right)$, wildlife habitat $\left(\mathrm{Chi}^{2}=19.41,5 \mathrm{df}\right)$, visual beauty $\left(\mathrm{Chi}^{2}=20.62,5 \mathrm{df}\right)$, timber production $\left(\mathrm{Chi}^{2}=17.29,5 \mathrm{df}\right)$ and hunting or fishing $\left(\mathrm{Chi}^{2}=15.86,5 \mathrm{df}\right)$ were the five most importantly ranked of the thirteen significant property uses of landowners wanting this type of assistance (Table 5-1). In the ANOVA these same uses of property were indicated on average to be more important for landowners interested in liability issues than those not requesting this type of assistance (Table 5-1).

(iii) Activities:

Fourteen activities conducted within property owned by respondents wanting liability, property rights and tax assistance were significant. Landowners interested in these issues tend to have removed grapevines $\left(\mathrm{Chi}^{2}=4.01,1 \mathrm{df}\right)$, improved forest health $\left(\mathrm{Chi}^{2}=11.77,1 \mathrm{df}\right)$, constructed trails $\left(\mathrm{Chi}^{2}=7.56,1 \mathrm{df}\right)$ and roads $\left(\mathrm{Chi}^{2}=2.73,1 \mathrm{df}\right)$, improved visual beauty $\left(\mathrm{Chi}^{2}=5.03\right.$, 1df) and water resources $\left(\mathrm{Chi}^{2}=3.76,1 \mathrm{df}\right)$ within their forest properties (Table 5-1). These six activities were indicated in the ANOVA as being on average more commonly conducted by landowners interested in these issues than those not interested (Table 5-1). 
(vi.) Assisting Agencies:

The respondents most likely to request this type of assistance have previously obtained help from the WV State Division of Forestry $\left(\mathrm{Chi}^{2}=17.67,1 \mathrm{df}\right)$, as well as the WVU Division of Forestry $\left(\mathrm{Chi}^{2}=6.60,1 \mathrm{df}\right)$ and Extension Service $\left(\mathrm{Chi}^{2}=6.01,1 \mathrm{df}\right)$. These same agencies were indicated in the ANOVA as being on average more commonly used in the past by landowners interested in these issues than those not wanting this topic of assistance (Table 5-2).

(v.) Logistic Regression Model (7df): Landowner Liability, Property Rights and Tax Assistance:

This model (7df) revealed that landowners of more recent ownership $(p=0.02)$ and higher incomes $(p=0.00)$ as well as using their property for an investment $(p=0.01)$ and ginseng or mushroom production ( $p=0.02$ ) tend to be more interested in these issues (Table). Respondents having forest health activities $(p=0.00)$ conducted within their property and previously receiving assistance from the West Virginia State Division of Forestry $(p=0.00)$ were also more likely to want this type of assistance. Even though thinning trees $(p=0.01)$ was a significant activity in this model, it was negatively correlated with requests for this type of assistance. This suggests that these landowners may want to know their rights before conducting tree thinnings, which also illustrates the importance of the property uses and activities that were positively correlated with landowners requesting liability assistance in that they want to protect their forest property investment.

This model $\left(\mathrm{Chi}^{2}=39.369,7 \mathrm{df}\right)$ correctly identified $69 \%$ and $64 \%$ of the landowners wanting and not wanting this type of assistance while producing odds of 3.9:1 that these significant characteristics can be used to identify those interested and not interested in these issues. The reduction in the $\mathrm{Chi}^{2}$-value between the first (39df) and second (7df) models was not significant, proving the second model to be parsimonious for identifying landowners wanting liability, property rights and tax assistance (Table 5-2). 
Appendix I-2

Table 5-1: Pearson's $\mathrm{Chi}^{2}$ and Analysis of Variance Values of Significance Dependent and Grouping Variable: Liability: p-Value Significant @ $\leq \mathbf{0 . 1 0}$

\begin{tabular}{|c|c|c|c|c|c|c|}
\hline $\begin{array}{l}p \text {-Value Significant } \leq 0.01^{* * *} \\
p \text {-Value Significant } \leq 0.05^{* *} \\
p \text {-Value Significant } \leq 0.10^{*}\end{array}$ & \multicolumn{2}{|c|}{$\begin{array}{l}\text { Pearson's } \\
\mathrm{CHI}^{2} \text { Analysis }\end{array}$} & Analysis of & $\begin{array}{l}\text { Variance }(A \\
\text { Liability Ass } \\
\text { Test of Mea }\end{array}$ & $\begin{array}{l}\text { OVA) } \\
\text { tance Reque } \\
\text { s (ANOVA) }\end{array}$ & \\
\hline INDEPENDENT VARIABLES & $\begin{array}{r}\mathrm{CHI}^{2} \text { Value } \\
\&\left(\mathrm{df}^{\circ}\right)\end{array}$ & $\begin{array}{c}\text { CHI }^{2} \\
\text { P-VALUE }\end{array}$ & $\begin{array}{l}\text { ANOVA } \\
\text { p-Value }\end{array}$ & $\begin{array}{c}\text { No }=0 \\
\text { Means (219) }\end{array}$ & $\begin{array}{c}\text { Yes }=1 \\
\text { Means (232) }\end{array}$ & $\begin{array}{l}\text { Difference }+/- \\
\text { Means (451) }\end{array}$ \\
\hline DEMOGRAPHICS & & & & & & \\
\hline PROPERTY LANDSIZE & $0.09(2)$ & 0.95 & 0.32 & 74.52 & 80.22 & +5.70 \\
\hline LANDOWNER TENURE & $14.90(2)$ & $\star \star \star 0.00$ & $* * * 0.00$ & 24.32 & 18.34 & -5.98 \\
\hline LANDOWNER INCOME & $23.00(4)$ & $\star \star * * 00$ & $\star \star \star 0.00$ & 2.90 & 3.69 & +0.79 \\
\hline LANDOWNER AGE & $12.96(2)$ & ${ }^{\star \star \star} 0.00$ & 0.68 & 55.14 & 54.41 & +0.27 \\
\hline LANDOWNER EDUCATION & $10.12(9)$ & 0.34 & $\star * \star 0.01$ & 3.99 & 4.66 & +0.67 \\
\hline PROPERTY USES & & & & & & \\
\hline LANDOWNERS PLACE OF RESIDENCE & $9.67(5)$ & ${ }^{*} 0.09$ & 0.97 & 3.79 & 3.80 & +0.01 \\
\hline PROPERTY AS AN INVESTMENT & $23.36(5)$ & $\star \star \star 0.00$ & $\star \star \star 0.00$ & 2.22 & 2.97 & +0.75 \\
\hline WILDLIFE HABITAT & $19.41(5)$ & $\star \star \star 0.00$ & $\star \star \star 0.00$ & 2.79 & 3.45 & +0.66 \\
\hline HUNTING OR FISHING & $15.86(5)$ & ${ }^{\star \star \star} 0.01$ & $\star \star * * 01$ & 2.41 & 2.86 & +0.45 \\
\hline WATESHED PROTECTION & $17.95(5)$ & ${ }^{\star \star *} 0.00$ & ${ }^{\star *} 0.04$ & 2.00 & 2.35 & +0.35 \\
\hline VISUAL BEAUTY & $20.62(5)$ & $\star \star \star * 0.00$ & $\star \star \star * 00$ & 2.74 & 3.44 & +0.70 \\
\hline HIKING OR BIKING & $19.74(5)$ & $\star \star \star 0.00$ & $\star \star \star 0.00$ & 1.60 & 2.09 & +0.49 \\
\hline TIMBER PRODUCTION & $17.29(5)$ & $\star \star * * 00$ & $\star \star \star 0.00$ & 2.40 & 2.94 & +0.54 \\
\hline CHRISTMAS TREE FARM & $17.81(5)$ & $\star \star \star 0.00$ & $* * \star 0.00$ & 0.79 & 1.09 & +0.30 \\
\hline FRUIT TREE ORCHARD & $13.58(5)$ & ${ }^{\star \star} 0.02$ & ${ }^{\star *} 0.04$ & 1.10 & 1.35 & +0.25 \\
\hline GINSENG OR MUSHROOM PRODUCTION & $17.61(5)$ & $\star \star \star 0.00$ & $\star \star \star 0.00$ & 0.89 & 1.31 & +0.42 \\
\hline LIVESTOCK PASTURE & $17.71(5)$ & $\star * \star 0.00$ & 0.23 & 2.08 & 2.29 & +0.21 \\
\hline FIREWOOD OR FENCE POSTS & $11.66(5)$ & ${ }^{\star \star} 0.04$ & ${ }^{\star \star} 0.02$ & 1.86 & 2.23 & +0.37 \\
\hline MAPLE SYRUP PRODUCTION & $12.38(5)$ & ${ }^{\star *} 0.03$ & ${ }^{\star \star *} 0.03$ & 0.78 & 0.97 & +0.19 \\
\hline OTHER USES & $11.73(5)$ & ${ }^{\star \star} 0.04$ & $\star \star \star * 01$ & 1.05 & 1.42 & +0.37 \\
\hline FOREST ACTIVITY & & & & & & \\
\hline TIMBER HARVESTING & $0.02(1)$ & 0.90 & 0.90 & 0.43 & 0.44 & +0.01 \\
\hline PLANTED TREES & $0.03(1)$ & 0.86 & 0.86 & 0.28 & 0.28 & 0.00 \\
\hline THINNED TREES & $0.01(1)$ & 0.92 & 0.92 & 0.38 & 0.38 & 0.00 \\
\hline CUT GRAPEVINES OR OTHER PLANTS & $4.01(1)$ & ${ }^{\star *} 0.05$ & ${ }^{\star *} 0.05$ & 0.40 & 0.50 & +0.10 \\
\hline IMPROVE VISUAL BEAUTY & $5.03(1)$ & ${ }^{\star \star} 0.02$ & ${ }^{* *} 0.02$ & 0.42 & 0.53 & +0.11 \\
\hline CONSTRUCTED TRAILS & 7.56 (1) & $\star \star \star 0.01$ & $\star \star \star 0.01$ & 0.31 & 0.43 & +0.12 \\
\hline CONSTRUCTED ROADS & $2.73(1)$ & ${ }^{*} 0.10$ & ${ }^{*} 0.10$ & 0.46 & 0.53 & +0.07 \\
\hline PLANTED WILDLIFE FOOD CROPS & $0.94(1)$ & 0.33 & 0.33 & 0.22 & 0.26 & +0.04 \\
\hline IMPROVED SOIL RESOURCES & $2.64(1)$ & ${ }^{*} 0.10$ & ${ }^{*} 0.10$ & 0.36 & 0.43 & +0.07 \\
\hline IMPROVED WATER RESOURCES & $3.76(1)$ & $\star \star 0.05$ & ${ }^{\star \star} 0.05$ & 0.34 & 0.43 & +0.09 \\
\hline NON-TIMBER PRODUCTS (GINSENG etc.) & $2.40(1)$ & 0.12 & 0.12 & 0.09 & 0.14 & +0.05 \\
\hline PROPERTY BOUNDARY SURVEYED & $1.07(1)$ & 0.30 & 0.30 & 0.32 & 0.37 & +0.05 \\
\hline CONTROLLED DAMAGING AGENTS & $11.77(1)$ & $\star \star \star * 0.00$ & $\star \star \star * 0.00$ & 0.14 & 0.27 & +0.13 \\
\hline LEASED PROPERTY (TIMBER OR REC.) & $2.74(1)$ & ${ }^{*} 0.10$ & ${ }^{*} 0.10$ & 0.01 & 0.04 & +0.03 \\
\hline OTHER FOREST ACTIVITIES & $2.01(1)$ & 0.16 & 0.16 & 0.09 & 0.13 & +0.04 \\
\hline ASSISTING AGENCIES & & & & & & \\
\hline
\end{tabular}


WWU DIVISION OF FORESTRY WVU EXTENSION SERVICE WV STATE DIVISION OF FORESTRY

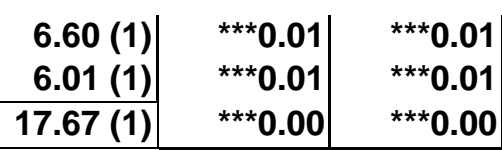

0.13
0.11
0.27

\section{Appendix I-3}

Table 5-2: Logistic Model (7df) Liability Assistance

Model: Logistic regression (logit) N of 0's:219 1's:232

Dep. var: LIABASST Loss: Max likelihood (MS-err. scaled to 1)

Final loss: $277.73727472 \mathrm{Chi}^{2}(7)=69.369 \mathrm{p}=.00000$

\begin{tabular}{|c|c|c|c|c|c|c|c|c|}
\hline \multicolumn{4}{|l|}{ LIABASST } & BASST & \multirow{2}{*}{\multicolumn{4}{|c|}{$\begin{array}{l}\text { Classification of Cases (owner.sta) } \\
\text { Odds ratio: } 3.9381\end{array}$}} \\
\hline \multirow{3}{*}{$\begin{array}{l}\text { Const.B0 } \\
\text { TENRGRUP }\end{array}$} & \multirow{2}{*}{$\begin{array}{c}\text { Estimate } \\
-0.83\end{array}$} & \multirow{2}{*}{$\begin{array}{l}\text { Std.Err. } \\
\mathbf{0 . 3 6}\end{array}$} & \multirow{2}{*}{$\begin{array}{l}\mathrm{t}(443) \\
-2.28\end{array}$} & \multirow{2}{*}{$\begin{array}{c}\text { p-level } \\
0.02\end{array}$} & & & & \\
\hline & & & & & & Pred. & Pred. & Percent \\
\hline & -0.25 & 0.11 & -2.27 & 0.02 & OBSERVED & 0 & 1 & Correct \\
\hline INCOME & 0.18 & 0.06 & 3.05 & 0.00 & 0 & 140 & 79 & 63.92694 \\
\hline INVESTM2 & 0.16 & 0.06 & 2.62 & 0.01 & 1 & 72 & 160 & 68.96552 \\
\hline GINSENG2 & 0.22 & 0.09 & 2.29 & 0.02 & & & & \\
\hline THINTREE & -0.61 & 0.23 & -2.69 & 0.01 & & & & \\
\hline FORHELTH & 0.75 & 0.26 & 2.84 & 0.00 & & & & \\
\hline WVFOREST & 0.70 & 0.22 & 3.13 & 0.00 & & & & \\
\hline
\end{tabular}

\footnotetext{
Determining significant change in $\mathrm{Chi}^{2}$-value from $39 \mathrm{df}$ to $7 \mathrm{df}$

for requests of Landowner Liability, Property Rights and Tax assistance.

A significant change in $\mathrm{Chi}^{2}$-value at the 0.10 alpha level would be equal to $\geq 46.04$.

Logistic Model (39df) Chi $^{2}$-value: 89.79

Logistic Model (7df) Chi' ${ }^{2}$-value: $\underline{-69.37}$

Difference

20.42

Result: there was no significant change in $\mathrm{Chi}^{2}$-value, because $20.42<46.06$.
} 


\section{Appendix J-1}

\section{$\underline{\text { Soil Resource Assistance }}$}

(i.) Demographics:

Three demographic characteristics were significant for the 225 landowners requesting soil resource assistance. Respondents owning forest property for 1-10 years (Chi $\left.{ }^{2}=7.26,2 \mathrm{df}\right)$, earning $>\$ 30,000$ per year $\left(\mathrm{Chi}^{2}=8.63,4 \mathrm{df}\right)$ and age $26-49$ years old $\left(\mathrm{Chi}^{2}=29.64,2 \mathrm{df}\right)$ were more likely to be interested in soil resource issues (Table 6-1). The ANOVA indicated that landowners requesting soil resource assistance tend to be on average more recent forest owners and average higher income levels than those not interested in this topic (Table 6-1).

(ii.) Property Uses:

The most importantly ranked of the fourteen significant property uses (Table 6-1) for landowners wanting soil resource assistance were residence, $\left(\mathrm{Chi}^{2}=10.17,5 \mathrm{df}\right)$, investment $\left(\mathrm{Chi}^{2}=17.96,5 \mathrm{df}\right)$, wildlife habitat $\left(\mathrm{Chi}^{2}=15.23,5 \mathrm{df}\right)$, hunting or fishing $\left(\mathrm{Chi}^{2}=16.47,5 \mathrm{df}\right)$, visual beauty $\left(\mathrm{Chi}^{2}=21.59,5 \mathrm{df}\right)$ and timber production $\left(\mathrm{Chi}^{2}=23.58,5 \mathrm{df}\right)$. These same uses of property were indicated in the ANOVA as being on average more important for landowners interested in soil resources than those not interested (Table 6-1).

(iii.) Activities:

Thirteen activities conducted within property owned by respondents interested in soil resource issues were significant (Table 6-1). Landowners wanting soil resource assistance tend to have implemented soil $\left(\mathrm{Chi}^{2}=15.14,1 \mathrm{df}\right)$ and water improvement practices $\left(\mathrm{Chi}^{2=} 4.29,1 \mathrm{df}\right)$, constructed roads $\left(\mathrm{Chi}^{2}=6.23,1 \mathrm{df}\right)$, improved visual beauty $\left(\mathrm{Chi}^{2}=4.49,1 \mathrm{df}\right)$ as well as conducted tree thinnings $\left(\mathrm{Chi}^{2}=3.80,1 \mathrm{df}\right)$ and grapevine control $\left(\mathrm{Chi}^{2}=5.80,1 \mathrm{df}\right)$ within their properties. The ANOVA revealed that landowners interested in soil resource assistance were more likely on average to conduct these same management practices than those not interested in soil issues (Table 6-1). 
(iv.) Assisting Agencies:

Landowners wanting soil resource assistance tend to have received help in the past from the WV State Division of Forestry $\left(\mathrm{Chi}^{2}=12.55,1 \mathrm{df}\right)$ and WVU Extension Service $\left(\mathrm{Chi}^{2}=4.92,1 \mathrm{df}\right)$. The ANOVA indicated that on average landowners requesting this topic were more likely to have previously received assistance from these same agencies than those not requesting soil resource assistance (Table 6-1).

(v.) Logistic Regression Model (7): Soil Resource Assistance:

This reduced model (7df) revealed that landowners wanting soil resource assistance were likely to be more recent forest owners $(p=0.07)$ with higher incomes $(p=0.03)$ while implementing fruit tree orchard $(p=0.05)$ and livestock pasturage $(p=0.01)$ property uses. They were also more likely to have already implemented soil $(p=0.09)$ and forest health $(p=0.09)$ improvement practices within their forest properties. Additionally, the WV State Division of Forestry $(p=0.01)$ was the public agency that respondents interested in soil resource issues tended to use in the past for obtaining management assistance. The positive relationship between these characteristics for this group of landowners suggests that they do acknowledge their need for soil management, which is important for the successful implementation of their property uses and forest management activities.

The model correctly identified $64 \%$ and $65 \%$ of those interested and not interested in soil resource issues $\left(\mathrm{Chi}^{2}=54.926,7 \mathrm{df}, \mathrm{p}=0.00\right)$ while producing odds of $3.3: 1$ that these characteristics can accurately predict landowners wanting and not wanting soil resource assistance. The reduction in the $\mathrm{Chi}^{2}$-value from the first (39df) to the second (7df) model was not significant making the second model parsimonious for identifying landowners interested in soil management issues (Table 6-2). 
Appendix J-2

Table 6-1: Pearson's $\mathrm{Chi}^{2}$ and Analysis of Variance Values of Significance

Dependent and Grouping Variable: Soil Resource: p-Value Significant $@ \leq \mathbf{0 . 1 0}$

\begin{tabular}{|c|c|c|c|c|c|c|}
\hline $\begin{array}{l}\text { p-Value Significant } \leq 0.01^{* * *} \\
\text { p-Value Significant } \leq 0.05^{* *} \\
p-\text { Value Significant } \leq 0.10^{*}\end{array}$ & \multicolumn{2}{|c|}{$\begin{array}{l}\text { Pearson's } \\
\mathrm{CHI}^{2} \text { Analysis }\end{array}$} & \multicolumn{4}{|c|}{\begin{tabular}{|ll} 
Analysis of Variance (ANOVA) \\
$\qquad \begin{array}{l}\text { Soil Resource Assistance Requests } \\
\text { Test of Means (ANOVA) }\end{array}$ \\
\end{tabular}} \\
\hline INDEPENDENT VARIABLES & $\begin{array}{r}\mathrm{CHI}^{2} \text { Value } \\
\&\left(\mathrm{df}^{\circ}\right)\end{array}$ & $\begin{array}{c}\text { CHI }^{2} \\
\text { P-VALUE }\end{array}$ & \begin{tabular}{|l|} 
ANOVA \\
p-Value
\end{tabular} & \begin{tabular}{|c|} 
No $=0$ \\
Means (226)
\end{tabular} & \begin{tabular}{c|} 
Yes $=1$ \\
Means (225)
\end{tabular} & $\begin{array}{c}\text { Difference }+/- \\
\text { Means (451) }\end{array}$ \\
\hline \multicolumn{7}{|l|}{ DEMOGRAPHICS } \\
\hline PROPERTY LANDSIZE & $0.15(2)$ & 0.93 & 0.17 & 73.56 & 81.36 & +7.80 \\
\hline LANDOWNER TENURE & $7.26(2)$ & $\star \star 0.03$ & $\star \star \star * 0.01$ & 23.31 & 19.17 & -4.14 \\
\hline LANDOWNER INCOME & $8.63(4)$ & ${ }^{\star} 0.07$ & ${ }^{\star \star \star} 0.00$ & 3.01 & 3.61 & +0.60 \\
\hline LANDOWNER AGE & $29.64(2)$ & $\star \star \star 0.00$ & 0.48 & 55.38 & 54.14 & -0.24 \\
\hline LANDOWNER EDUCATION & $8.12(9)$ & 0.52 & 0.14 & 4.15 & 4.52 & +0.37 \\
\hline \multicolumn{7}{|l|}{ PROPERTY USES } \\
\hline LANDOWNERS PLACE OF RESIDENCE & $10.17(5)$ & ${ }^{*} 0.07$ & ${ }^{\star *} 0.05$ & 3.62 & 3.96 & +0.34 \\
\hline PROPERTY AS AN INVESTMENT & $17.96(5)$ & $\star \star \star * 0.00$ & $\star \star \star 0.00$ & 2.30 & 2.91 & +0.61 \\
\hline WILDLIFE HABITAT & $15.23(5)$ & $\star \star * 0.01$ & $\star \star \star 0.00$ & 2.83 & 3.44 & +0.61 \\
\hline HUNTING OR FISHING & $16.47(5)$ & $\star \star \star * 0.01$ & $\star \star \star 0.01$ & 2.39 & 2.89 & +0.50 \\
\hline WATESHED PROTECTION & $13.36(5)$ & ${ }^{* \star} 0.02$ & $\star \star \star 0.00$ & 1.91 & 2.44 & +0.53 \\
\hline VISUAL BEAUTY & $21.59(5)$ & $\star \star \star 0.00$ & $\star \star \star * 0.00$ & 2.78 & 3.43 & +0.65 \\
\hline HIKING OR BIKING & $16.67(5)$ & $\star * \star 0.01$ & ${ }^{\star *} 0.05$ & 1.69 & 2.01 & +0.32 \\
\hline TIMBER PRODUCTION & $23.58(5)$ & $\star \star \star * 0.00$ & $\star \star \star 0.01$ & 2.46 & 2.90 & +0.44 \\
\hline CHRISTMAS TREE FARM & $19.01(5)$ & $\star \star \star 0.00$ & $\star \star \star 0.00$ & 0.81 & 1.09 & +0.28 \\
\hline FRUIT TREE ORCHARD & $27.73(5)$ & ${ }^{\star \star *} 0.00$ & $\star \star \star 0.00$ & 0.97 & 1.48 & +0.51 \\
\hline GINSENG OR MUSHROOM PRODUCTION & $18.30(5)$ & $\star \star \star * 0.00$ & $\star \star \star 0.00$ & 0.93 & 1.27 & +0.34 \\
\hline LIVESTOCK PASTURE & $33.51(5)$ & $\star \star \star * 0.00$ & $\star \star \star * 00$ & 1.88 & 2.49 & +0.61 \\
\hline FIREWOOD OR FENCE POSTS & $7.46(5)$ & 0.19 & ${ }^{*} 0.08$ & 1.91 & 2.19 & +0.28 \\
\hline MAPLE SYRUP PRODUCTION & $16.77(5)$ & $\star \star \star 0.00$ & $\star \star \star 0.00$ & 0.75 & 1.00 & +0.25 \\
\hline OTHER USES & $15.34(5)$ & $\star \star \star * 01$ & ${ }^{* *} 0.02$ & 1.08 & 1.41 & +0.33 \\
\hline \multicolumn{7}{|l|}{ FOREST ACTIVITY } \\
\hline TIMBER HARVESTING & $1.63(1)$ & 0.20 & 0.20 & 0.40 & 0.46 & +0.06 \\
\hline PLANTED TREES & $3.68(1)$ & ${ }^{\star} 0.06$ & $\star 0.06$ & 0.24 & 0.32 & +0.08 \\
\hline THINNED TREES & $3.18(1)$ & ${ }^{\star} 0.07$ & ${ }^{\star} 0.08$ & 0.34 & 0.42 & +0.08 \\
\hline CUT GRAPEVINES OR OTHER PLANTS & $5.80(1)$ & $\star \star 0.02$ & **0.02 & 0.39 & 0.51 & +0.12 \\
\hline IMPROVE VISUAL BEAUTY & $4.49(1)$ & $* \star 0.03$ & ${ }^{* *} 0.03$ & 0.43 & 0.53 & +0.10 \\
\hline CONSTRUCTED TRAILS & $5.19(1)$ & ${ }^{* \star} 0.02$ & ${ }^{\star \star} 0.02$ & 0.32 & 0.42 & +0.10 \\
\hline CONSTRUCTED ROADS & $6.23(1)$ & $\star \star \star 0.01$ & $\star * \star 0.01$ & 0.44 & 0.56 & +0.12 \\
\hline PLANTED WILDLIFE FOOD CROPS & $8.28(1)$ & $\star \star \star 0.00$ & $\star * \star * 0.00$ & 0.19 & 0.30 & +0.11 \\
\hline IMPROVED SOIL RESOURCES & $15.14(1)$ & $\star \star \star * 0.00$ & $\star * \star * 0.00$ & 0.31 & 0.48 & +0.17 \\
\hline IMPROVED WATER RESOURCES & $4.29(1)$ & ${ }^{\star \star} 0.04$ & ${ }^{\star \star} 0.04$ & 0.34 & 0.43 & +0.09 \\
\hline NON-TIMBER PRODUCTS (GINSENG etc.) & 3.19 (1) & ${ }^{*} 0.07$ & ${ }^{*} 0.07$ & 0.09 & 0.14 & +0.05 \\
\hline PROPERTY BOUNDARY SURVEYED & $7.31(1)$ & $\star \star \star * 0.01$ & $\star \star \star * 01$ & 0.29 & 0.41 & +0.12 \\
\hline CONTROLLED DAMAGING AGENTS & $8.00(1)$ & $\star \star \star 0.00$ & $\star \star \star 0.00$ & 0.15 & 0.26 & +0.11 \\
\hline LEASED PROPERTY (TIMBER OR REC.) & $0.33(1)$ & 0.56 & 0.56 & 0.03 & 0.02 & -0.01 \\
\hline OTHER FOREST ACTIVITIES & $5.05(1)$ & ${ }^{\star *} 0.02$ & ${ }^{\star *} 0.02$ & 0.08 & 0.15 & +0.07 \\
\hline ASSISTING AGENCIES & & & & & & \\
\hline
\end{tabular}


WVU DIVISION OF FORESTRY WVU EXTENSION SERVICE

WV STATE DIVISION OF FORESTRY

\begin{tabular}{r|r|r}
$1.92(1)$ & 0.17 & 0.17 \\
$\mathbf{4 . 9 2}(\mathbf{1})$ & ${ }^{\star \star} 0.03$ & ${ }^{\star \star} 0.03$ \\
$\mathbf{1 2 . 5 5}(\mathbf{1})$ & ${ }^{\star \star \star} \mathbf{0 . 0 0}$ & ${ }^{\star \star *} 0.00$
\end{tabular}

0.15
0.12
0.29

0.20

$+0.05$

$+0.08$

$+0.16$

\section{Appendix J-3}

Table 6-2: Logistic Model (7df) Soil Resource Assistance

Model: Logistic regression (logit) N of 0's:226 1's:225

Dep. var: SOILASST Loss: Max likelihood (MS-err. scaled to 1)

Final loss: $285.14551312 \mathrm{Chi}^{2}(7)=54.926 \mathrm{p}=.00000$

\begin{tabular}{|c|c|c|c|c|c|c|c|c|}
\hline \multicolumn{4}{|l|}{ SOILASST } & SOILASST & \multirow{2}{*}{\multicolumn{4}{|c|}{$\begin{array}{l}\text { Classification of Cases (owner.sta) } \\
\text { Odds ratio: } 3.3080\end{array}$}} \\
\hline & Estimate & Std.Err. & $\mathrm{t}(443)$ & p-level & & & & \\
\hline Const.B0 & -1.02 & 0.36 & -2.82 & 0.01 & & Pred. & Pred. & Percent \\
\hline TENRGRUP & -0.20 & 0.11 & -1.82 & 0.07 & OBSERVED & 0 & 1 & Correct \\
\hline INCOME & 0.13 & 0.06 & 2.17 & 0.03 & 0 & 147 & 79 & 65.04425 \\
\hline FRUITRE2 & 0.17 & 0.09 & 1.95 & 0.05 & 1 & 81 & 144 & 64 \\
\hline LIVSTOC2 & 0.16 & 0.06 & 2.76 & 0.01 & & & & \\
\hline IMPVSOIL & 0.37 & 0.22 & 1.71 & 0.09 & & & & \\
\hline FORHELTH & 0.44 & 0.26 & 1.71 & 0.09 & & & & \\
\hline WVFOREST & 0.58 & 0.22 & 2.70 & 0.01 & & & & \\
\hline
\end{tabular}

\footnotetext{
Determining significant change in $\mathrm{Chi}^{2}$-value from 39df to $7 \mathrm{df}$

for requests of Soil Resource assistance.

A significant change in $\mathrm{Chi}^{2}$-value at the 0.10 alpha level would be equal to $\geq 46.04$.

Logistic Model (39df) Chi $^{2}$-value: 77.68

Logistic Model (7df) Chi ${ }^{2}$-value: $\underline{-54.93}$

Difference 22.75

Result: there was no significant change in $\mathrm{Chi}^{2}$-value, because $22.75<46.06$.
} 


\section{Appendix K-1}

\section{$\underline{\text { Visual Beauty Assistance }}$}

(i.) Demographics:

For the 224 landowners interested in visual beauty resources, four demographic characteristics were significant. Respondents owning forest property from 1-10 years $\left(\mathrm{Chi}^{2}=13.30,2 \mathrm{df}\right)$ in the southern region of $\mathrm{WV}\left(\mathrm{Chi}^{2}=7.61,3 \mathrm{df}\right)$, earning $>\$ 30,000$ per year $\left(\mathrm{Chi}^{2}=9.79,4 \mathrm{df}\right)$ and age $26-49$ years old $\left(\mathrm{Chi}^{2}=13.21,2 \mathrm{df}\right)$ were more likely to want visual beauty assistance (Table 7-1). The ANOVA revealed that landowners interested in visual beauty issues tend to average less years of forest ownership and higher incomes than those not interested in this topic of assistance (Table 7-1).

(ii.) Property Uses:

The most important of the fourteen significant property uses for landowners wanting visual beauty assistance (Table $7-1)$ were visual beauty $\left(\mathrm{Chi}^{2}=50.86,5 \mathrm{df}\right)$, wildlife habitat $\left(\mathrm{Chi}^{2}=36.29,5 \mathrm{df}\right)$, timber production $\left(\mathrm{Chi}^{2}=15.17,5 \mathrm{df}\right)$, hunting or fishing, $\left(\mathrm{Chi}^{2}=10.44,5 \mathrm{df}\right)$ watershed protection $\left(\mathrm{Chi}^{2}=18.37,5 \mathrm{df}\right)$ and investment $\left(\mathrm{Chi}^{2}=14.23,5 \mathrm{df}\right)$. These same property uses were identified in the ANOVA as being on average more important for landowners interested in visual beauty management than for those not interested in this topic (Table 7-1).

(iii.) Activities:

Eight activities conducted within property owned by respondents wanting visual beauty assistance were significant (Table 7-1). Landowners interested in visual beauty issues tend to have conducted visual beauty $\left(\mathrm{Chi}^{2}=12.45,1 \mathrm{df}\right)$ and soil $\left(\mathrm{Chi}^{2}=3.42,1 \mathrm{df}\right)$ resource improvements, built trails $\left(\mathrm{Chi}^{2}=5.53,1 \mathrm{df}\right)$ as well as implemented tree thinning $\left(\mathrm{Chi}^{2}=5.94,1 \mathrm{df}\right)$ and grapevine control $\left(\mathrm{Chi}^{2}=4.48,1 \mathrm{df}\right)$ practices. The ANOVA revealed that on average these practices were more commonly implemented by landowners wanting visual beauty assistance than those not wanting this topic (Table 7-1).

(iv.) Assisting Agencies: 
Landowners wanting visual beauty assistance tend to have previously received help from the WV State Division of Forestry $\left(\mathrm{Chi}^{2}=4.48,1 \mathrm{df}\right)$ as well as from the WVU Division of Forestry $\left(\mathrm{Chi}^{2}=4.48,1 \mathrm{df}\right)$ and Extension Service $\left(\mathrm{Chi}^{2}=4.48,1 \mathrm{df}\right)$. In the ANOVA, respondents wanting visual beauty assistance on average were more likely to have previously received assistance from these same agencies than landowners not interested in visual beauty issues (Tables 7-1). (v.) Logistic Regression Model (3df): Visual Beauty Assistance:

The model indicates that landowners wanting visual beauty assistance tend to use their forest property for visual beauty enjoyment $(p=0.00)$ while also being more likely to conduct forest health or pest management practices $(p=0.01)$ within their property. They also tend to have received assistance in the past from the WV State Division of Forestry $(p=0.00)$. The positive relationship between these characteristics for this group of landowners suggest that they do realize the need to protect their forest property from fire, disease and insects in order to sustain the aesthetics of their forest property while also recognize a need for assistance.

This model $\left(\mathrm{Chi}^{2}=66.252,3 \mathrm{df}, \mathrm{p}=0.00\right)$ correctly identified $69 \%$ and $58 \%$ of the respondents wanting and not wanting visual beauty assistance while producing odds of $3.1: 1$ that these variables can predict landowners interested and not interested in visual beauty issues. The reduction in $\mathrm{Chi}^{2}$-value from the first (39df) to the second (3df) model was not significant proving the second model parsimonious for identifying landowners wanting visual beauty assistance (Table 7-2). 
Appendix K-1

Table 7-1: Pearson's $\mathrm{Chi}^{2}$ and Analysis of Variance Values of Significance

Dependent and Grouping Variable: Visual Beauty: p-Value Significant $@ \leq \mathbf{0 . 1 0}$

\begin{tabular}{|c|c|c|c|c|c|c|}
\hline $\begin{array}{l}p \text {-Value Significant } \leq 0.01^{* * *} \\
p-\text { Value Significant } \leq 0.05^{* *} \\
p-\text { Value Significant } \leq 0.10^{*}\end{array}$ & \multicolumn{2}{|c|}{$\begin{array}{l}\text { Pearson's } \\
\mathrm{CHI}^{2} \text { Analysis }\end{array}$} & Analysis of & $\begin{array}{l}\text { Variance }(\mathrm{Al} \\
\text { Visual Beaut } \\
\text { Test of Mear }\end{array}$ & $\begin{array}{l}\text { VOVA) } \\
\text { Assistance } \\
\text { Is (ANOVA) }\end{array}$ & Requests \\
\hline INDEPENDENT VARIABLES & $\begin{array}{r}\mathrm{CHI}^{2} \text { Value } \\
\&\left(\mathrm{df}^{\circ}\right)\end{array}$ & $\begin{array}{c}\mathrm{CHI}^{2} \\
\text { P-VALUE }\end{array}$ & $\begin{array}{l}\text { ANOVA } \\
\text { p-Value }\end{array}$ & \begin{tabular}{|c|} 
No $=0$ \\
Means (227)
\end{tabular} & $\begin{array}{c}\text { Yes }=1 \\
\text { Means (224) }\end{array}$ & $\begin{array}{l}\text { Difference +/- } \\
\text { Means (451) }\end{array}$ \\
\hline DEMOGRAPHICS & & & & & & \\
\hline PROPERTY LANDSIZE & $0.63(2)$ & 0.73 & 0.84 & 78.02 & 76.88 & -1.14 \\
\hline LANDOWNER TENURE & $13.30(2)$ & $* \star * 0.00$ & $\star \star \star * 0.00$ & 23.32 & 19.14 & -4.18 \\
\hline LANDOWNER INCOME & $9.79(4)$ & ${ }^{\star \star} 0.04$ & $\star \star \star 0.01$ & 3.10 & 3.53 & +0.43 \\
\hline LANDOWNER AGE & $13.21(2)$ & ${ }^{\star * \star} 0.00$ & 0.73 & 55.07 & 54.45 & -0.62 \\
\hline LANDOWNER EDUCATION & $6.83(9)$ & 0.66 & 0.35 & 4.22 & 4.45 & +0.23 \\
\hline PROPERTY USES & & & & & & \\
\hline LANDOWNERS PLACE OF RESIDENCE & $18.95(5)$ & ${ }^{\star \star *} 0.00$ & ${ }^{\star *} 0.05$ & 3.62 & 3.97 & +0.35 \\
\hline PROPERTY AS AN INVESTMENT & $14.23(5)$ & $\star \star \star 0.01$ & $\star \star \star 0.00$ & 2.31 & 2.90 & +0.59 \\
\hline WILDLIFE HABITAT & $36.29(5)$ & $* * * 0.00$ & $\star \star \star 0.00$ & 2.67 & 3.60 & +0.93 \\
\hline HUNTING OR FISHING & $10.44(5)$ & ${ }^{\star} 0.06$ & ${ }^{\star \star} 0.03$ & 2.44 & 2.84 & +0.40 \\
\hline WATESHED PROTECTION & $18.37(5)$ & $* \star * 0.00$ & $\star \star \star * 0.00$ & 1.86 & 2.50 & +0.64 \\
\hline VISUAL BEAUTY & $50.86(5)$ & $\star \star \star 0.00$ & $\star \star \star 0.00$ & 2.51 & 3.70 & +1.19 \\
\hline HIKING OR BIKING & $20.00(5)$ & $\star * \star 0.00$ & $* * * 0.00$ & 1.57 & 2.14 & +0.57 \\
\hline TIMBER PRODUCTION & $15.17(5)$ & $\star \star \star * 0.01$ & $\star \star \star 0.00$ & 2.43 & 2.92 & +0.49 \\
\hline CHRISTMAS TREE FARM & $18.39(5)$ & $* * * 0.00$ & $\star \star \star 0.00$ & 0.77 & 1.13 & +0.36 \\
\hline FRUIT TREE ORCHARD & $22.44(5)$ & $\star \star \star * 0.00$ & $\star \star \star * 00$ & 1.00 & 1.46 & +0.46 \\
\hline GINSENG OR MUSHROOM PRODUCTION & $14.89(5)$ & $\star \star * * 01$ & $\star * \star 0.00$ & 0.92 & 1.29 & +0.37 \\
\hline LIVESTOCK PASTURE & $15.93(5)$ & $\star \star \star * 0.01$ & 0.16 & 2.07 & 2.31 & +0.24 \\
\hline FIREWOOD OR FENCE POSTS & $6.86(5)$ & 0.23 & ${ }^{\star \star} 0.04$ & 1.89 & 2.21 & +0.32 \\
\hline MAPLE SYRUP PRODUCTION & $15.86(5)$ & $\star * \star 0.01$ & $\star * \star 0.00$ & 0.74 & 1.02 & +0.28 \\
\hline OTHER USES & $16.32(5)$ & ${ }^{\star \star *} 0.01$ & $\star * * 0.00$ & 1.03 & 1.46 & +0.43 \\
\hline FOREST ACTIVITY & & & & & & \\
\hline TIMBER HARVESTING & $2.40(1)$ & 0.12 & 0.12 & 0.40 & 0.47 & +0.07 \\
\hline PLANTED TREES & $1.82(1)$ & 0.18 & 0.18 & 0.25 & 0.31 & +0.06 \\
\hline THINNED TREES & $5.94(1)$ & $\star * \star 0.01$ & $\star \star \star 0.01$ & 0.33 & 0.44 & +0.11 \\
\hline CUT GRAPEVINES OR OTHER PLANTS & $4.48(1)$ & ${ }^{\star \star} 0.03$ & ${ }^{\star *} 0.03$ & 0.40 & 0.50 & +0.10 \\
\hline IMPROVE VISUAL BEAUTY & $12.45(1)$ & $\star * * 0.00$ & $\star \star \star * 0.00$ & 0.40 & 0.56 & +0.16 \\
\hline CONSTRUCTED TRAILS & $5.53(1)$ & ${ }^{* \star} 0.02$ & ${ }^{\star \star} 0.02$ & 0.32 & 0.42 & +0.10 \\
\hline CONSTRUCTED ROADS & $1.61(1)$ & 0.20 & 0.20 & 0.47 & 0.53 & +0.06 \\
\hline PLANTED WILDLIFE FOOD CROPS & $11.36(1)$ & $\star \star \star * 0.00$ & $\star \star \star 0.00$ & 0.18 & 0.31 & +0.13 \\
\hline IMPROVED SOIL RESOURCES & $3.42(1)$ & ${ }^{*} 0.06$ & ${ }^{*} 0.06$ & 0.35 & 0.44 & +0.09 \\
\hline IMPROVED WATER RESOURCES & $2.45(1)$ & 0.12 & 0.12 & 0.35 & 0.42 & +0.07 \\
\hline NON-TIMBER PRODUCTS (GINSENG etc.) & $2.33(1)$ & 0.13 & 0.13 & 0.09 & 0.14 & +0.05 \\
\hline PROPERTY BOUNDARY SURVEYED & $6.63(1)$ & $\star \star \star * 0.01$ & $\star \star \star 0.01$ & 0.29 & 0.41 & +0.12 \\
\hline CONTROLLED DAMAGING AGENTS & $8.27(1)$ & $* * * 0.00$ & $\star \star \star 0.00$ & 0.15 & 0.26 & +0.11 \\
\hline LEASED PROPERTY (TIMBER OR REC.) & $1.43(1)$ & 0.23 & 0.23 & 0.02 & 0.04 & +0.02 \\
\hline OTHER FOREST ACTIVITIES & $1.93(1)$ & 0.16 & 0.17 & 0.09 & 0.13 & +0.04 \\
\hline ASSISTING AGENCIES & & & & & & \\
\hline
\end{tabular}


WWU DIVISION OF FORESTRY WVU EXTENSION SERVICE WV STATE DIVISION OF FORESTRY

\begin{tabular}{r|r|r|}
$3.70(1)$ & ${ }^{\star \star} 0.05$ & ${ }^{* \star} 0.05$ \\
$6.34(1)$ & ${ }^{* \star *} 0.01$ & ${ }^{\star \star *} 0.01$ \\
$22.89(1)$ & ${ }^{\star \star *} 0.00$ & ${ }^{* \star *} 0.00$
\end{tabular}

$22.89(1)$
${ }^{\star \star *} 0.00$
0.14
0.11
0.26

\section{Appendix K-3}

Table 7-2: Logistic Model (3df) Visual Beauty Assistance

\begin{tabular}{|c|c|c|c|c|c|c|c|c|}
\hline \multicolumn{6}{|c|}{$\begin{array}{l}\text { Model: Logistic regression (logit) } \mathrm{N} \text { of } 0 \text { 's: } 2271 \text { 's:224 } \\
\text { Dep. var: BUTYASST Loss: Max likelihood (MS-err. scaled to 1) } \\
\text { Final loss: } 279.473 \mathrm{Chi}^{2}(3)=66.252 \mathrm{p}=.00000\end{array}$} & \multicolumn{3}{|c|}{$\begin{array}{l}-2^{*} \log \text { (Likelihood) } 553.9470 \\
\text { Intercept Only: } 625.1988\end{array}$} \\
\hline BUTYASST & & & & YASST & \multirow{2}{*}{\multicolumn{4}{|c|}{$\begin{array}{l}\text { Classification of Cases (owner.sta) } \\
\text { Odds ratio: } 3.0568\end{array}$}} \\
\hline \multirow{3}{*}{$\begin{array}{l}\text { Const.B0 } \\
\text { VISULBU2 }\end{array}$} & \multirow{2}{*}{$\begin{array}{l}\text { Estimate } \\
-1.46\end{array}$} & \multirow{2}{*}{$\begin{array}{l}\text { Std.Err. } \\
0.23\end{array}$} & \multirow{2}{*}{$\begin{array}{l}\mathrm{t}(445) \\
-6.43\end{array}$} & \multirow{3}{*}{$\begin{array}{c}\text { p-level } \\
0.00 \\
0.00\end{array}$} & & & & \\
\hline & & & & & & Pred. & Pred. & Percent \\
\hline & 0.33 & 0.06 & 5.68 & & OBSERVED & 0 & 1 & Correct \\
\hline FORHELTH & 0.62 & 0.25 & 2.44 & 0.01 & 0 & 132 & 95 & 58.14978 \\
\hline WVFOREST & 0.77 & 0.21 & 3.65 & 0.00 & 1 & 70 & 154 & 68.75 \\
\hline
\end{tabular}

Determining significant change in $\mathrm{Chi}^{2}$-value from 39df to $3 \mathrm{df}$ for requests of Visual Beauty assistance.

A significant change in $\mathrm{Chi}^{2}$-value at the 0.10 alpha level would be equal to $\geq 46.04$.

Logistic Model (39df) Chi $^{2}$-value: 98.21

Logistic Model (3df) Chi ${ }^{2}$-value: $\underline{-66.25}$

Difference 31.96

Result: there was no significant change in $\mathrm{Chi}^{2}$-value, because $31.96<46.06$. 


\section{Appendix L-1}

\section{Dendrology Assistance}

(i.) Demographics:

Five demographic characteristics were significant for the 193 landowners interested in dendrology issues (Table 8-1). Respondents owning forest property for $1-10$ years $\left(\mathrm{Chi}^{2}=27.68\right.$, $2 \mathrm{df})$ in the southern region of $\mathrm{WV}\left(\mathrm{Chi}^{2}=6.34,3 \mathrm{df}\right)$, earning $>\$ 30,000$ per year $\left(\mathrm{Chi}^{2}=15.31,4 \mathrm{df}\right)$, having attended college $\left(\mathrm{Chi}^{2}=16.71,9 \mathrm{df}\right)$ and age 50-64 years $\left(\mathrm{Chi}^{2}=22.64,2 \mathrm{df}\right)$ were more likely to want dendrology assistance. The ANOVA indicated that landowners interested in dendrology tend to average less years of forest ownership and have higher average income levels than those not wanting this topic (Table 8-1).

(ii.) Property Uses:

Investment $\left(\mathrm{Chi}^{2}=24.30,5 \mathrm{df}\right)$, wildlife habitat $\left(\mathrm{Chi}^{2}=20.87,5 \mathrm{df}\right)$, hunting or fishing $\left(C h i^{2}=18.96,5 d f\right)$, watershed protection $\left(\mathrm{Chi}^{2}=20.80,5 \mathrm{df}\right)$, visual beauty $\left(\mathrm{Chi}^{2}=31.71,5 \mathrm{df}\right)$ and timber production $\left(\mathrm{Chi}^{2}=21.74,5 \mathrm{df}\right)$ were the most important of the fifteen significant property uses for landowners wanting dendrology assistance (Table 8-1). The ANOVA indicated these same uses of property on average were more important for landowners interested in dendrology assistance than those not interested in this topic (8-1).

(iii.) Activities:

Ten activities conducted within property owned by respondents wanting dendrology assistance were significant (Table 8-1). Landowners interested in dendrology issues were more likely to implement tree thinning $\left(\mathrm{Chi}^{2}=7.95,1 \mathrm{df}\right)$ and grapevine control $\left(\mathrm{Chi}^{2}=8.38,1 \mathrm{df}\right)$ practices, improve visual resources $\left(\mathrm{Chi}^{2}=5.73,1 \mathrm{df}\right)$ as well as build trails $\left(\mathrm{Chi}^{2}=7.12,1 \mathrm{df}\right)$ and access roads $\left(\mathrm{Chi}^{2}=3.73,1 \mathrm{df}\right)$. These same practices were indicated in the ANOVA as being on average more commonly implemented by landowners interested in dendrology than for those not interested in this topic (Table 8-1). 
(vi.) Assisting Agencies:

Landowners requesting dendrology also tended to have previously received help from the WV State Division of Forestry $\left(\mathrm{Chi}^{2}=14.15,1 \mathrm{df}\right)$ and the WVU Extension Service $\left(\mathrm{Chi}^{2}=6.31,1 \mathrm{df}\right)$. The ANOVA indicated that landowners interested in dendrology on average tend to have previously received assistance more from these same agencies than those not wanting this topic (Table 8-1).

(v.) Logistic Regression Model (4df): Dendrology Assistance:

This reduced model (4df) revealed that landowners interested in dendrology issues tend be more recent owners $(p=0.00)$ while using their forest property for investment $(p=0.00)$ and also being more likely to plant wildlife food crops $(p=0.00)$. Additionally, they also tend to have received assistance in the past from the WV State Division of Forestry $(p=0.02)$. The positive relationship between these characteristics indicates an understanding by this group of landowners that the valuation and success of a forest investment often depends on the ability to correctly identify and know the growth requirements of forest plants, especially tree and shrub species.

The model $\left(\mathrm{Chi}^{2}=56.825,4 \mathrm{df}, \mathrm{p}=0.00\right)$ correctly identified $47 \%$ and $80 \%$ of the respondents wanting and not wanting dendrology assistance while producing odds of $3.6: 1$ that these characteristics can predict landowners interested and not interested in dendrology issues. In addition, the reduction in the $\mathrm{Chi}^{2}$-value from the first (39df) to the second (4df) model was not significant making the second model parsimonious for identifying landowners interested in the identification and growth requirements of forest plants (Table 8-2). 


\section{Appendix L-2}

Table 8-3: Pearson's $\mathrm{Chi}^{2}$ and Analysis of Variance Values of Significance

Dependent and Grouping Variable: Dendrology Assistance: p-Value Significant @ $\leq \mathbf{0 . 1 0}$

\begin{tabular}{|c|c|c|c|c|c|c|}
\hline $\begin{array}{l}p \text {-Value Significant } \leq 0.01^{* *} \\
p-\text { Value Significant } \leq 0.05^{* *} \\
p \text {-Value Significant } \leq 0.10^{*}\end{array}$ & \multicolumn{2}{|c|}{$\begin{array}{l}\text { Pearson's } \\
\mathrm{CHI}^{2} \text { Analysis }\end{array}$} & Analysis of & $\begin{array}{l}\text { Variance }(A) \\
\text { Dendrology } \\
\text { Test of Mea }\end{array}$ & $\begin{array}{l}\text { JOVA) } \\
\text { ssistance Re } \\
\text { s (ANOVA) }\end{array}$ & quests \\
\hline INDEPENDENT VARIABLES & $\begin{array}{r}\mathrm{CHI}^{2} \text { Value } \\
\&\left(\mathrm{df}^{\circ}\right)\end{array}$ & $\begin{array}{c}\mathrm{CHI}^{2} \\
\text { P-VALUE }\end{array}$ & $\begin{array}{l}\text { ANOVA } \\
\text { p-Value }\end{array}$ & $\begin{array}{c}\text { No }=0 \\
\text { Means (258) }\end{array}$ & $\begin{array}{c}\text { Yes }=1 \\
\text { Means (193) }\end{array}$ & $\begin{array}{l}\text { Difference +/- } \\
\text { Means (451) }\end{array}$ \\
\hline DEMOGRAPHICS & & & & & & \\
\hline PROPERTY LANDSIZE & $0.81(2)$ & 0.67 & 0.18 & 74.11 & 81.93 & +7.82 \\
\hline LANDOWNER TENURE & $27.68(2)$ & $\star \star \star * 0.00$ & $\star \star \star * * 00$ & 24.25 & 17.23 & -7.02 \\
\hline LANDOWNER INCOME & $15.41(4)$ & ${ }^{\star \star \star} 0.00$ & ${ }^{\star \star *} 0.00$ & 3.10 & 3.60 & +0.50 \\
\hline LANDOWNER AGE & $22.64(2)$ & $\star \star \star \star 0.00$ & 0.14 & 55.88 & 53.26 & -2.62 \\
\hline LANDOWNER EDUCATION & $16.71(9)$ & ${ }^{\star \star} 0.05$ & 0.33 & 4.23 & 4.47 & +0.24 \\
\hline PROPERTY USES & & & & & & \\
\hline LANDOWNERS PLACE OF RESIDENCE & $10.60(5)$ & ${ }^{\star} 0.06$ & 0.22 & 3.70 & 3.92 & +0.22 \\
\hline PROPERTY AS AN INVESTMENT & $24.30(5)$ & $* * * 0.00$ & $\star \star \star * 0.00$ & 2.27 & 3.05 & +0.78 \\
\hline WILDLIFE HABITAT & $20.87(5)$ & $\star \star \star 0.00$ & $\star \star \star * 0.00$ & 2.81 & 3.56 & +0.75 \\
\hline HUNTING OR FISHING & $18.96(50$ & ${ }^{\star \star \star} 0.00$ & ${ }^{\star \star *} 0.00$ & 2.35 & 3.03 & +0.68 \\
\hline WATESHED PROTECTION & $20.80(5)$ & $\star \star \star 0.00$ & $\star \star \star * 0.00$ & 1.88 & 2.58 & +0.70 \\
\hline VISUAL BEAUTY & $31.71(5)$ & $\star \star \star 0.00$ & $\star \star \star * 0.00$ & 2.71 & 3.62 & +0.91 \\
\hline HIKING OR BIKING & $34.49(5)$ & $\star \star * 0.00$ & $\star \star \star 0.00$ & 1.56 & 2.24 & +0.68 \\
\hline TIMBER PRODUCTION & $21.74(5)$ & $\star \star \star 0.00$ & $\star \star * * 0.00$ & 2.43 & 3.01 & +0.58 \\
\hline CHRISTMAS TREE FARM & $22.35(5)$ & $\star \star \star 0.00$ & $\star \star \star * 0.00$ & 0.77 & 1.18 & +0.41 \\
\hline FRUIT TREE ORCHARD & $29.70(5)$ & $\star \star \star * 0.00$ & $\star \star \star \star 0.00$ & 0.98 & 1.56 & +0.58 \\
\hline GINSENG OR MUSHROOM PRODUCTION & $32.55(5)$ & $\star \star \star * 0.00$ & $\star * * * 0.00$ & 0.90 & 1.37 & +0.47 \\
\hline LIVESTOCK PASTURE & $16.62(5)$ & ${ }^{\star \star \star} 0.01$ & ${ }^{\star} 0.08$ & 2.06 & 2.36 & +0.3 \\
\hline FIREWOOD OR FENCE POSTS & $12.70(5)$ & ${ }^{\star \star} 0.03$ & ${ }^{* \star *} 0.01$ & 1.88 & 2.28 & +0.40 \\
\hline MAPLE SYRUP PRODUCTION & $24.22(5)$ & $\star \star \star 0.00$ & $\star \star \star * 0.00$ & 0.73 & 1.07 & +0.34 \\
\hline OTHER USES & $20.28(5)$ & $\star \star \star 0.00$ & $\star \star \star 0.00$ & 1.00 & 1.57 & +0.57 \\
\hline FOREST ACTIVITY & & & & & & \\
\hline TIMBER HARVESTING & $1.14(1)$ & 0.29 & 0.29 & 0.41 & 0.46 & +0.05 \\
\hline PLANTED TREES & $6.56(1)$ & $\star \star 0.01$ & $\star \star \star 0.01$ & 0.23 & 0.34 & +0.11 \\
\hline THINNED TREES & $7.95(1)$ & ${ }^{\star \star \star} 0.00$ & ${ }^{\star \star *} 0.00$ & 0.33 & 0.46 & +0.13 \\
\hline CUT GRAPEVINES OR OTHER PLANTS & $8.38(1)$ & $\star \star \star * 0.00$ & $\star \star \star * * 00$ & 0.39 & 0.53 & +0.14 \\
\hline IMPROVE VISUAL BEAUTY & $5.73(1)$ & ${ }^{\star \star} 0.02$ & ${ }^{\star \star} 0.02$ & 0.43 & 0.54 & +0.11 \\
\hline CONSTRUCTED TRAILS & $7.12(1)$ & $\star \star \star 0.01$ & $\star * \star * 0.01$ & 0.32 & 0.44 & +0.12 \\
\hline CONSTRUCTED ROADS & $3.72(1)$ & ${ }^{\star \star} 0.05$ & ${ }^{* *} 0.05$ & 0.46 & 0.55 & +0.09 \\
\hline PLANTED WILDLIFE FOOD CROPS & $15.78(1)$ & $\star \star \star 0.00$ & $\star \star \star * 0.00$ & 0.17 & 0.34 & +0.17 \\
\hline IMPROVED SOIL RESOURCES & $0.88(1)$ & 0.35 & 0.35 & 0.38 & 0.42 & +0.04 \\
\hline IMPROVED WATER RESOURCES & $0.94(1)$ & 0.33 & 0.33 & 0.36 & 0.41 & +0.05 \\
\hline NON-TIMBER PRODUCTS (GINSENG etc.) & $10.26(1)$ & ${ }^{\star \star \star} 0.00$ & ${ }^{\star \star \star} 0.00$ & 0.07 & 0.17 & +0.10 \\
\hline PROPERTY BOUNDARY SURVEYED & $7.62(1)$ & $\star * \star 0.01$ & $\star * \star * 0.01$ & 0.29 & 0.42 & +0.13 \\
\hline CONTROLLED DAMAGING AGENTS & $1.77(1)$ & 0.18 & 0.18 & 0.18 & 0.23 & +0.05 \\
\hline LEASED PROPERTY (TIMBER OR REC.) & $2.87(1)$ & ${ }^{*} 0.09$ & *0.09 & 0.02 & 0.04 & +0.02 \\
\hline OTHER FOREST ACTIVITIES & $1.57(1)$ & 0.21 & 0.21 & 0.10 & 0.13 & +0.03 \\
\hline
\end{tabular}




\begin{tabular}{|l|r|r|r|r|r|r|}
\hline ASSISTING AGENCIES & & & & & & \\
WVU DIVISION OF FORESTRY & $2.40(1)$ & 0.12 & 0.12 & 0.15 & 0.21 & +0.06 \\
WVU EXTENSION SERVICE & $\mathbf{6 . 3 1}(\mathbf{1}$ & ${ }^{* \star \star} 0.01$ & ${ }^{* \star *} \mathbf{0 . 0 1}$ & $\mathbf{0 . 1 2}$ & $\mathbf{0 . 2 1}$ & $\mathbf{+ 0 . 0 9}$ \\
WV STATE DIVISION OF FORESTRY & $\mathbf{1 4 . 1 5}(\mathbf{1})$ & ${ }^{* \star \star} \mathbf{0 . 0 0}$ & ${ }^{* \star *} \mathbf{0 . 0 0}$ & $\mathbf{0 . 3 0}$ & $\mathbf{0 . 4 7}$ & $\mathbf{+ 0 . 1 7}$ \\
\hline
\end{tabular}

\section{Appendix L-3}

Table 8-2: Logistic Model (4df) Dendrology Assistance

Model: Logistic regression (logit) N of 0's:258 1's:193

Dep. var: DENDRO Loss: Max likelihood (MS-err. scaled to 1)

Final loss: $279.49662627 \mathrm{Chi}^{2}(4)=56.825 \mathrm{p}=.00000$

\begin{tabular}{|c|c|c|c|c|c|c|c|c|}
\hline \multicolumn{4}{|l|}{ DENDRO } & DENDRO & \multirow{2}{*}{\multicolumn{4}{|c|}{$\begin{array}{l}\text { Classification of Cases (owner.sta) } \\
\text { Odds ratio: } 3.6211\end{array}$}} \\
\hline & Estimate & Std.Err. & $t(446)$ & p-level & & & & \\
\hline Const.BO & -0.38 & 0.31 & -1.26 & 0.21 & & Pred. & Pred. & Percent \\
\hline TENRGRUP & -0.42 & 0.11 & -3.83 & 0.00 & OBSERVED & 0 & 1 & Correct \\
\hline INVESTM2 & 0.22 & 0.06 & 3.77 & 0.00 & 0 & 207 & 51 & 80.23256 \\
\hline WILDFOOD & 0.70 & 0.23 & 2.97 & 0.00 & 1 & 102 & 91 & 47.15026 \\
\hline WVFOREST & 0.49 & 0.21 & 2.35 & 0.02 & & & & \\
\hline
\end{tabular}

\footnotetext{
Determining significant change in $\mathrm{Chi}^{2}$-value from 39df to $4 \mathrm{df}$

for requests of Dendrology assistance.

A significant change in $\mathrm{Chi}^{2}$-value at the 0.10 alpha level would be equal to $\geq 46.04$.

Logistic Model (39df) Chi $^{2}$-value: 94.48

Logistic Model (4df) Chi' ${ }^{2}$-value: $\underline{-56.83}$

Difference $\quad 37.65$

Result: there was no significant change in $\mathrm{Chi}^{2}$-value, because $37.65<46.06$.
}

$-2^{\star} \log$ (Likelihood) 558.9932

Intercept Only: 615.8180 


\section{Appendix M-1}

\section{Forestland or Timber Valuation Assistance}

(i.) Demographics:

Six demographic characteristics were significant for the 192 landowners interested in the valuation of timber or forestland (Table 9-1). Respondents owning 100-199 acres $\left(\mathrm{Chi}^{2}=6.84\right.$, 2df) for $1-10$ years $\left(\mathrm{Chi}^{2}=7.84,2 \mathrm{df}\right)$ in the southern region of $\mathrm{WV}\left(\mathrm{Chi}^{2}=7.67,3 \mathrm{df}\right)$ and age $26-49$ years old $\left(\mathrm{Chi}^{2}=11.19,2 \mathrm{df}\right)$ were more likely to want valuation assistance. In addition, they tend to have an income level of $>\$ 30,000$ per year $\left(\mathrm{Chi}^{2}=11,48,4 \mathrm{df}\right)$ and a Masters level college education $\left(\mathrm{Chi}^{2}=22.77,9 \mathrm{df}\right)$. The ANOVA indicated that respondents interested in valuation issues tend to have on average significantly larger properties and higher incomes than those not requesting this topic do. They also tend to average less years of forest ownership than respondents not interested in valuation issues (Table 9-1).

(ii.) Property Uses:

The most importantly ranked of the nine significant property uses (Table 9-1) for respondents wanting valuation assistance were timber production $\left(\mathrm{Chi}^{2}=63.98,5 \mathrm{df}\right)$, visual beauty $\left(\mathrm{Chi}^{2}=32.19,5 \mathrm{df}\right)$, investment $\left(\mathrm{Chi}^{2}=40.25,5 \mathrm{df}\right)$, wildlife habitat $\left(\mathrm{Chi}^{2}=18.64,5 \mathrm{df}\right)$ and hunting or fishing $\left(\mathrm{Chi}^{2}=23.03,5 \mathrm{df}\right)$. These same uses were indicated in the ANOVA as being on average more important for landowners interested in valuation issues than for those not interested in this topic (Table 9-1).

(iii.) Activities:

Landowners wanting valuation assistance tend to have implemented grapevine removal $\left(\mathrm{Chi}^{2}=15.32,1 \mathrm{df}\right)$ and other (fencing) practices $\left(\mathrm{Chi}^{2}=15.97,1 \mathrm{df}\right)$ as well as constructed trails $\left(\mathrm{Chi}^{2}=6.48,1 \mathrm{df}\right)$ within their property (Table 9-1). They were also more likely to lease their property for timber or recreation $\left(\mathrm{Chi}^{2}=2.93,1 \mathrm{df}\right)$ and have the property boundaries surveyed $\left(\mathrm{Chi}^{2}=4.98,1 \mathrm{df}\right)$. The ANOVA revealed that landowners interested in forestland or timber 
valuation issues were more likely on average to engage in these forestry practices than respondents not interested in this assistance topic were (Table 9-1).

(iv.) Assisting Agencies:

The WVU Division of Forestry $\left(\mathrm{Chi}^{2}=9.60,1 \mathrm{df}\right)$ and Extension Service $\left(\mathrm{Chi}^{2}=5.26,1 \mathrm{df}\right)$ as well as the WV State Division of Forestry $\left(\mathrm{Chi}^{2}=38.45,1 \mathrm{df}\right)$ were the most likely agencies to have previously helped respondents wanting forest valuation assistance (Table 9-1). These same agencies were indicated in the ANOVA as being more likely on average to have previously assisted landowners interested in timber or forestland valuation issues than those not wanting this topic (Table 9-1).

(v.) Logistic Regression Model (4df): Forestland or Timber Valuation:

This model (4df) revealed that landowners wanting timber or forestland valuation assistance tend to use their property for investment $(p=0.00)$ and timber production $(p=0.00)$ while also being more likely to implement other (fencing) forestry practices $(p=0.00)$. In addition, landowners interested in valuation issues tend to have received help in the past from the WV State Division of Forestry $(p=0.00)$. The positive relationship between these characteristics suggests that this group of landowners realize that proper valuation and protection of their forest assets (land or timber) can be complicated and often requires professional assistance.

The model $\left(\mathrm{Chi}^{2}=92.218,4 \mathrm{df}, \mathrm{p}=0.00\right)$ correctly identified $59 \%$ and $76 \%$ of the landowners interested and not interested in valuation issues while producing odds of 4.5:1 that these characteristics can predict landowners wanting and not wanting timber or forestland valuation assistance. The reduction in $\mathrm{Chi}^{2}$-value from the first (39df) to the second (4df) model was not significant making the second model parsimonious for identifying landowners interested in forest valuation issues (Table 9-2). 
Table 9-1: Pearson's $\mathrm{Chi}^{2}$ to Analysis of Variance Values of Significance

Dependent and Grouping Variable: Valuation Assistance: p-Value Significant @ $\leq \mathbf{0 . 1 0}$

\begin{tabular}{|c|c|c|c|c|c|c|}
\hline $\begin{array}{l}\text { p-Value Significant } \leq 0.01^{* * *} \\
p-\text { Value Significant } \leq 0.05^{* *} \\
p-\text { Value Significant } \leq 0.10^{*}\end{array}$ & \multicolumn{2}{|c|}{$\begin{array}{l}\text { Pearson's } \\
\mathrm{CHI}^{2} \text { Analysis }\end{array}$} & \multicolumn{4}{|c|}{\begin{tabular}{|l} 
Analysis of Variance (ANOVA) \\
$\qquad \begin{array}{l}\text { Valuation Assistance Requests } \\
\text { Test of Means (ANOVA) }\end{array}$ \\
\end{tabular}} \\
\hline INDEPENDENT VARIABLES & $\begin{array}{r}\mathrm{CHI}^{2} \text { Value } \\
\&\left(\mathrm{df}^{\circ}\right)\end{array}$ & $\begin{array}{c}\text { CHI }^{2} \\
\text { P-VALUE }\end{array}$ & \begin{tabular}{|l|} 
ANOVA \\
p-Value
\end{tabular} & $\begin{array}{c}\text { No }=0 \\
\text { Means (259) }\end{array}$ & \begin{tabular}{c|} 
Yes $=1$ \\
Means (192)
\end{tabular} & $\begin{array}{c}\text { Difference +/- } \\
\text { Means (451) }\end{array}$ \\
\hline DEMOGRAPHICS & & & & & & \\
\hline PROPERTY LANDSIZE & $6.84(2)$ & ${ }^{\star \star} 0.03$ & ${ }^{\star \star *} 0.00$ & 70.41 & 86.96 & +16.55 \\
\hline LANDOWNER TENURE & $7.84(2$ & $\star \star 0.02$ & ${ }^{\star \star} 0.03$ & 22.66 & 19.33 & -3.33 \\
\hline LANDOWNER INCOME & $11.48(4)$ & ${ }^{\star \star} 0.02$ & $* * 0.00$ & 3.08 & 3.63 & +0.55 \\
\hline LANDOWNER AGE & $11.19(2)$ & $\star \star \star * 0.00$ & 0.72 & 55.03 & 54.40 & -0.63 \\
\hline LANDOWNER EDUCATION & $22.77(9)$ & $\star \star \star 0.01$ & $* \star * 0.00$ & 4.00 & 4.78 & +0.78 \\
\hline PROPERTY USES & & & & & & \\
\hline LANDOWNERS PLACE OF RESIDENCE & $19.56(5)$ & ${ }^{* \star *} 0.00$ & 0.40 & 3.86 & 3.71 & -0.15 \\
\hline PROPERTY AS AN INVESTMENT & $40.25(5)$ & $\star \star \star 0.00$ & ${ }^{\star * \star} 0.00$ & 2.19 & 3.16 & +0.97 \\
\hline WILDLIFE HABITAT & $18.64(5)$ & $\star \star \star 0.00$ & $\star \star \star * 0.01$ & 2.95 & 3.39 & +0.44 \\
\hline HUNTING OR FISHING & $23.03(5)$ & $\star \star \star 0.00$ & ${ }^{\star *} 0.02$ & 2.46 & 2.88 & +0.42 \\
\hline WATESHED PROTECTION & $23.38(5)$ & $\star \star \star * 0.00$ & ${ }^{* *} 0.03$ & 2.02 & 2.40 & +0.38 \\
\hline VISUAL BEAUTY & $32.19(5)$ & $\star \star \star 0.00$ & $\star \star \star \star 0.00$ & 2.78 & 3.54 & +0.76 \\
\hline HIKING OR BIKING & $24.01(5)$ & ${ }^{\star \star \star} 0.00$ & $\star \star \star 0.01$ & 1.67 & 2.10 & +0.43 \\
\hline TIMBER PRODUCTION & $63.98(5)$ & ${ }^{\star \star \star} 0.00$ & ${ }^{\star * *} 0.00$ & 2.16 & 3.37 & +1.21 \\
\hline CHRISTMAS TREE FARM & $13.59(5)$ & ${ }^{\star \star} 0.02$ & ${ }^{\star \star} 0.05$ & 0.86 & 1.06 & +0.20 \\
\hline FRUIT TREE ORCHARD & $21.28(5)$ & $\star \star \star 0.00$ & 0.35 & 1.18 & 1.29 & +0.11 \\
\hline GINSENG OR MUSHROOM PRODUCTION & $21.92(5)$ & $\star \star \star 0.00$ & 0.72 & 1.08 & 1.13 & +0.05 \\
\hline LIVESTOCK PASTURE & $24.29(5)$ & $\star \star \star 0.00$ & 0.76 & 2.17 & 2.22 & +0.05 \\
\hline FIREWOOD OR FENCE POSTS & $20.66(5)$ & $\star \star \star 0.00$ & 0.12 & 1.95 & 2.19 & +0.24 \\
\hline MAPLE SYRUP PRODUCTION & $14.12(5)$ & $\star \star \star 0.01$ & 0.34 & 0.84 & 0.93 & +0.09 \\
\hline OTHER USES & $16.36(5)$ & $\star \star \star * 0.01$ & ${ }^{\star \star *} 0.01$ & 1.08 & 1.47 & +0.39 \\
\hline FOREST ACTIVITY & & & & & & \\
\hline TIMBER HARVESTING & $1.32(1)$ & 0.25 & 0.25 & 0.41 & 0.46 & +0.05 \\
\hline PLANTED TREES & $1.29(1)$ & 0.26 & 0.26 & 0.26 & 0.31 & +0.05 \\
\hline THINNED TREES & $2.32(1)$ & 0.13 & 0.13 & 0.35 & 0.42 & +0.07 \\
\hline CUT GRAPEVINES OR OTHER PLANTS & $15.52(1)$ & $\star * \star 0.00$ & $\star * \star * 0.00$ & 0.37 & 0.56 & +0.19 \\
\hline IMPROVE VISUAL BEAUTY & $0.92(1)$ & 0.34 & 0.34 & 0.46 & 0.51 & +0.05 \\
\hline CONSTRUCTED TRAILS & $6.48(1)$ & $\star \star \star * 0.01$ & $* * * 01$ & 0.32 & 0.44 & +0.12 \\
\hline CONSTRUCTED ROADS & $1.15(1)$ & 0.28 & 0.28 & 0.47 & 0.53 & +0.06 \\
\hline PLANTED WILDLIFE FOOD CROPS & $0.23(1)$ & 0.63 & 0.63 & 0.24 & 0.26 & +0.02 \\
\hline IMPROVED SOIL RESOURCES & $0.68(1)$ & 0.41 & 0.41 & 0.38 & 0.42 & +0.04 \\
\hline IMPROVED WATER RESOURCES & $0.73(1)$ & 0.39 & 0.40 & 0.37 & 0.41 & +0.04 \\
\hline NON-TIMBER PRODUCTS (GINSENG etc.) & $0.73(1)$ & 0.39 & 0.39 & 0.10 & 0.13 & +0.03 \\
\hline PROPERTY BOUNDARY SURVEYED & $4.98(1)$ & $* * 0.03$ & ${ }^{\star *} 0.03$ & 0.31 & 0.41 & +0.10 \\
\hline CONTROLLED DAMAGING AGENTS & $1.90(1)$ & 0.17 & 0.17 & 0.18 & 0.23 & +0.05 \\
\hline LEASED PROPERTY (TIMBER OR REC.) & $2.93(1)$ & ${ }^{*} 0.09$ & *0.09 & 0.02 & 0.04 & +0.02 \\
\hline
\end{tabular}




\begin{tabular}{|c|c|c|c|c|c|c|}
\hline OTHER FOREST ACTIVITIES & $15.97(1)$ & ${ }^{\star \star *} 0.00$ & $* * * 0.00$ & 0.06 & 0.18 & +0.12 \\
\hline ASSISTING AGENCIES & & & & & & \\
\hline WVU DIVISION OF FORESTRY & $9.60(1)$ & ${ }^{\star \star *} 0.00$ & ${ }^{\star \star \star} 0.00$ & 0.13 & 0.24 & +0.11 \\
\hline WVU EXTENSION SERVICE & $5.26(1)$ & ${ }^{\star \star} 0.02$ & ${ }^{* *} 0.02$ & 0.12 & 0.20 & +0.08 \\
\hline WV STATE DIVISION OF FORESTRY & $38.45(1)$ & $\star \star \star * 0.00$ & ${ }^{\star * \star} 0.00$ & 0.25 & 0.54 & +0.29 \\
\hline
\end{tabular}

\section{Appendix M-3}

Table 9-2: Logistic Model (4df) Valuation Assistance

Model: Logistic regression (logit) N of 0's:259 1's:192

Dep. var: VALUASST Loss: Max likelihood (MS-err. scaled to 1)

Final loss: $261.50541958 \mathrm{Chi}^{2}(4)=92.218 \mathrm{p}=.00000$

\begin{tabular}{|c|c|c|c|c|c|c|c|c|}
\hline \multicolumn{4}{|l|}{ VALUASST } & VALUASST & \multirow{2}{*}{\multicolumn{4}{|c|}{$\begin{array}{l}\text { Classification of Cases (owner.sta) } \\
\text { Odds ratio: } 4.4501\end{array}$}} \\
\hline \multirow{3}{*}{$\begin{array}{l}\text { Const.B0 } \\
\text { INVESTM2 }\end{array}$} & \multirow{3}{*}{$\begin{array}{c}\text { Estimate } \\
-2.11 \\
0.20\end{array}$} & \multirow{3}{*}{$\begin{array}{c}\text { Std.Err. } \\
0.26 \\
0.06\end{array}$} & \multirow{3}{*}{$\begin{array}{c}\mathrm{t}(446) \\
-8.03 \\
3.12\end{array}$} & \multirow{3}{*}{\begin{tabular}{|c|} 
p-level \\
0.00 \\
0.00
\end{tabular}} & & & & \\
\hline & & & & & & Pred. & Pred. & Percent \\
\hline & & & & & OBSERVED & 0 & 1 & Correct \\
\hline TIMBERP2 & 0.29 & 0.06 & 4.48 & 0.00 & 0 & 196.00 & 63.00 & 75.68 \\
\hline OTHERACT & 1.02 & 0.34 & 2.97 & 0.00 & 1 & 79.00 & 113.00 & 58.85 \\
\hline WVFOREST & 0.88 & 0.22 & 4.02 & 0.00 & & & & \\
\hline
\end{tabular}

\footnotetext{
Determining significant change in $\mathrm{Chi}^{2}$-value from $39 \mathrm{df}$ to $4 \mathrm{df}$

for requests of Valuation assistance.

A significant change in $\mathrm{Chi}^{2}$-value at the 0.10 alpha level would be equal to $\geq 46.04$.

Logistic Model (39df) Chi ${ }^{2}$-value: 128.53

Logistic Model (4df) Chi $^{2}$-value: $-\underline{92.22}$

Difference

36.31

Result: there was no significant change in $\mathrm{Chi}^{2}$-value, because $36.31<46.06$.
}

$-2^{*} \log$ (Likelihood) 523.0109 Intercept Only: 615.2284 


\section{Appendix N}

The Stand Visualization System (SVS) " generates computer graphic images depicting forest stand conditions represented by a list of individual stand components, e.g., trees, shrubs, and down material using detailed geometric models. The images produced by SVS, while abstract, provide a readily understood representation of stand conditions and help communicate silvicultural treatments and forest management alternatives to a variety of audiences."

SVS provides the following capabilities:

- Displays stand information represented by a list of individual plant and log components in a realistic, although abstract fashion

- Displays stand information in a manner that communicates the overall structural diversity present within the stand

- Differentiates between stand components using different plant forms, colors, or other types of marking

- Displays overhead, profile and perspective views of a stand

- Provides a mechanism that allows users to define plant forms and colors based on species, growth form, and plant position within the canopy

- Provides tabular and graphical summaries of stand information before and after a silvicultural treatment

- Facilitates the design of silvicultural treatments by allowing users to select (or mark) stand components and specify treatments

- Displays information describing individual stand components as they are selected by the user

"SVS is executable on IBM-compatible personal computers using the MS-DOS operating system (or a compatible operating system) and requires no specialized hardware or additional software."

Table 1: SVS Data Requirements

\begin{tabular}{|c|c|c|c|}
\hline Species code & Height & Crown radius 2 & Expansion factor \\
Plant identifier & Lean angle & Crown ratio 2 & Marking status \\
Tree Class & Felling angle & Crown radius 3 & Postion \\
Crown Class & End diameter & Crown ratio 3 & Postion \\
Plant status & Crown radius 1 & Crown radius 4 & Elevation \\
Diameter & Crown ratio 1 & Crown ratio 4 & \\
\hline
\end{tabular}

(McGaughey, 1998) 


\section{References}

Allen, Thomas J., Dennis Smith, and Anthony Ferris (1997), Real Property:

Leasing Land for Hunting and Other Recreational Uses, (No. 726, August), Charleston, West Virginia: WVU Extension Service. 1-9.

Bailey, Brent (1997), Class Notes from Forest Policy Class 220:

Morgantown, West Virginia: West Virginia University.

Best, Constance, and Laurie Wayburn (1995), "In Diversity Is Wealth," Journal of Forestry, 93 (August), 7-10.

Birch, Thomas W. (1996), Private Forest-land Owners of the Northern United States, (180-189). Radnor, PA: USDA Forest Service.

Burke, Mark (1999), West Virginia Woodland Owners Association.

Carvell, Kenneth L., and William L. Maxey (1998), Protectors of the Forest

Resources, 1-37. Charleston, WV: West Virginia Division of Forestry.

DiGiovanni, Dawn M. (1990), Forest Statistics for West Virginia--1975 and 1989, (Tables 103-104). Radnor, PA: USDA Forest Service.

Dowdy, Shirley, and Stanley Wearden (1985), Statistics for Research.

New York, NY: John Wiley \& Sons. (105-136, 283-336)

Fajvan, Mary Ann, Shawn Grushecky, and Curt Hasseler (1998)

"The Effects of Harvesting Practices on West Virginia's Wood Supply," Journal of Forestry, 98 (May), 33-39.

Flora, Cornelia B. (1992), Rural Communities Legacy \& Change.

Boulder, Colorado: West View Press. 32-37, 96-208.

Forest Stewardship Committee, et al., (1997), West Virginia Forest

Stewardship Incentive Program (SIP, FSP, FIP), (PI. 1-10 \& S. 1-10),

Charleston, West Virginia: West Virginia Division of Forestry.

Francis, Cinda (1998), West Virginia Forestry Association and Tree Farm Committee

Fraser, Rory, and Daniel Magill (2000), Forest Management Planning on Non-Industrial Private Forestlands in West Virginia. Paper submitted to the Northern Journal of Applied Forestry Spring 2000.

Fraser, Rory, and Daniel Magill (2000), Forest Management Assistance and Non-Industrial Private Forestland Owners in West Virginia. Paper submitted to Southern Forest Economics Workshop: Spring 2000.

Gracey, Eric, and Matthew H. Pelkki (1996), Comparing Kentucky Woodland Owners 
Association Members to the Non-industrial Private Landowners Population in Kentucky In Proceedings of Symposium on Non-industrial Private Forests: Learning from the Past, Prospects for the Future. Minnesota Extension Service, U. of Minn., St. Paul, MN. 403-410.

Grafton, William (2000), Services Provided by the WVU Wildlife Extension Service

Grasser, Paul W., and Jo Ellen Force (1996), Early and Late Adopters of Stewardship Planning In Proceedings of Symposium on Non-industrial Private Forests: Learning from the Past, Prospects for the Future. Minnesota Extension Service, U. of Minn., St. Paul, MN. 222-229.

Greenstreet, David, and Raymond Caldwell Jr. (1997), Economic Impact of the Wood Products Industry, 2-5. West Virginia University, W V: Bureau of Business and Economic Research.

Hayes, Fred (1998), Personal Comments: Center for Economic Options. Charleston, WV.

Hosmer, and Lemeshow (1989), Applied Logistic Regression. New York, NY: John Wiley \& Sons. 1-173.

Magill, Daniel J. (2000), Non-Industrial-Private-Forest Owner Case Study Summarization West Virginia University: Morgantown, WV

Magill, Daniel J., Rory Fraser, Ray Hicks and Robert Whipkey (2000), Forest Resource Management on Private Forestlands in West Virginia. Paper under review by the West Virginia University Agriculture and Forestry Experiment Station. Morgantown, WV.

Mahraj and Carpenter. (1997), The Economic Importance of Sport Fishing 1-7. Alexandria, VA: Southwick Associates.

Maser, Chris (1994), Sustainable Forestry: Philosophy, Science and Economics. Delray Beach, Fl: St. Lucie Press. 36-37, 235-236.

McEvoy, Thom J. (1998), Legal Aspects of Owning and Managing Woodlands Washington D.C.: Island Press. 11-15.

McGaughey, Robert J. (1998), Stand Visualization System 9-10. USDA Forest Service Pacific Northwest Research Station.

Meyers,Todd. (1997, December 9), Council Documents Tourism's Economic Impacts. Charleston Gazette, 1-3.

Mills, W.L. Jr., William L. Hoover, Sudha Vassan, Kevin T. McNamara, and Venkatarao Nagubadi (1996), In Proceedings of Symposium on Non-industrial Private Forests: Learning from the Past, Prospects for the Future. Minnesota Extension Service, U. of Minn., St. Paul, MN. 222-229.

NRCS, West Virginia (1998), Wildlife Habitat Incentives Program 1-4. Charleston, WV: Natural Resources Conservation Service.

Pahl, Tim (1998), Appalachian Hardwood Center. West Virginia University, Morgantown, WV:

Perkey, Arlyn (2000), USDA Forest Service. Morgantown, WV

Schmidt, John (2000), USDA Fish \& Wildlife Service. Elkins, WV 
Teisl, M. (1998), The Economic Importance of Hunting 1-10.

The Economic Benefits of Watchable Wildlife Recreation 1-9.

Alexandria, VA: Southwick Associates.

Sypolt, Cliff (1999), USDA Farm Service Agency: Provided assistance to conduct pilot tests and information to develop mail survey sample.

Westvaco Corp. (1999), Cooperative Forest Management Program

West Virginia University Extension Service (1999), Provided funding to conduct NIPF owner Interviews and case studies.

Whipkey, Robert (1998), Forest Stewardship and Forest Incentive Programs Charleston, WV: West Virginia Division of Forestry.

White, David (1993), West Virginia's Second Forest (22 ${ }^{\text {nd }}$ ed. 1-3),

West Virginia University, W V: Agriculture and Forestry Experimental Station. 